
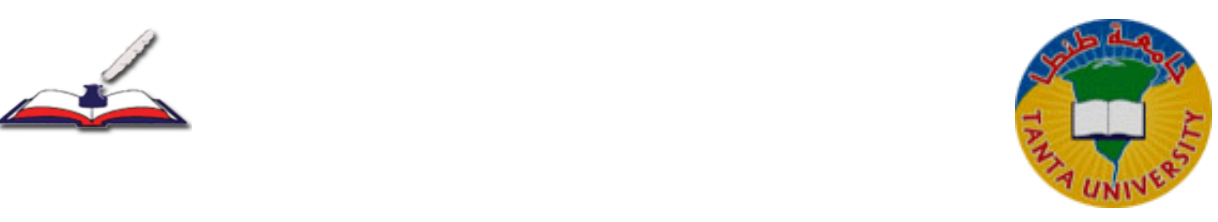

أثر برنامج تدريبي مبني على نظرية التعلم المستند إلى الاماغ في تحسين

تقدير الذات والدافعية للإنجاز لاى طالبات كلية الأميرة عالية الجامعية

جامعة البلقاء التطبيقية

\author{
إعداد \\ أ.م..د/ محمد عبد الله جبر العارضة \\ أستاذ علم النفس التربوي المساعد \\ جامعة البلقاء التطبيقية ـ كلية الأميرة عالية الجامعية \\ قسم علم النفس و التربية الخاصة
}

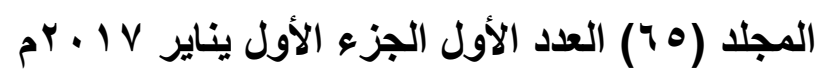




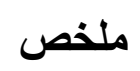

هدفت هذه الدراسة إلى استقصاء أثر برنامج تدريبي مبني على نظرية التعلم المستند إلى الدماغ في تحسين تقدير الذات والدافعية للإنجاز لدى طالبات كلية الأمبرة عالية الجامعية/ جامعة البلقاء التطبيقية بالأردن.حيث تم استخدام المنهج شبه التجريبي. وقد بلغ عدد أفر اد الدراسة (75) طالبة، تم اختيار هن بالطريقة القصدية في شعبتين لمساق علم النفس التربويخلال الفصل الأول من العام الجامعي (2017/2016)، وقد تكونت المجموعة التجريبية التي خضعت للبرنامج التدريبي من (40) طالبـة، بينما تكونت المجموعة الضابطة التي لم تتعرض للبرنامج التدريبي من (35) طالبـة. وقد استخدم الباحث مقياس تقدير الذاتلروزنبرغ (Rosenberg, 1965) المعرب من من قبـل جر ادات (2006)، ومقيـاس الدافعيـة للإنجـاز للعز ام (2013). و أظهرت نتائج الدر اســة وجـود فروق ذات دلالـة إحصـائية بـين المجمو عــة التجريبيـة و المجمو عـة الضابطة في تحسين تقدير الذات والدافعيـة للإنجـاز ، لصـالح المجمو عـة التجريبيـة، تعزى إلى البرنامج التدريبي المبني على نظرية التعلم المستند إلى الدماغ. الكلمات المفتاحية: التعلم المستند إلى الدماغ، تقدير الذات، الدافعية للإنجاز. 


\begin{abstract}
This study aims to investigate the impact of a training program built on Brain-based learning theory in improving self-esteem and achievement motivation among the students of Princess Alia University College/ Al-Balqa' Applied University in Jordan. The study used the semi-experimental approach. The total number of students in this study was (75), who were selected by purposive sample from two sections of the Educational Psychology course during the first semester of the academic year (2016/2017). The experimental group was composed of (40) students, while the control group, which did not formally go through any part of the training program, consisted of (35) students. Rosenberg's selfesteem scale and Alazzam's achievement motivation scale were used. The study results showed statistically significant differences in self-esteem and achievement motivation in favor of the experimental group. These differences were attributed to the brain-based training program.
\end{abstract}

Keywords:Brain-based learning theory, Self-esteem, Achievement motivation. 
مقدمة

يفرض العصر الحالي على كل من له صلة مباثرة أو غير مباثرة بالعطلية التعليمية

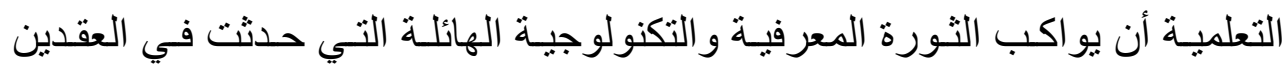
الأخيرين، وتوظيفما أمكن من نتائج أبحاث علم النفس التربوي المتعلقة بالعملية التعليمية في الغرفة الصفية بهدف تغيير البنية التقليدية لها، وتحقيق الهدف النهائي للموقف الصفي الذي كان يعتمد على المعلم، لينتقل إلى إيجاد مساحة واسعة ومناسبة لثخصية المتعلم بما يحمله من أفكار يوظفها من خلال العمليات المعرفية المعقدة. ويشير تريفل (2006) أن فهم تفاصيل كيفية قيام الدماغ بوظائفه هي إحدى مهام العلم المستمر . لذلك يؤكدجينسن (2007) أن العلماء حاولوا منذ قرون فلك شيفرة

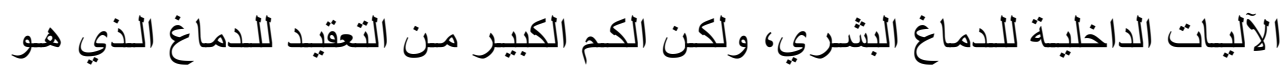

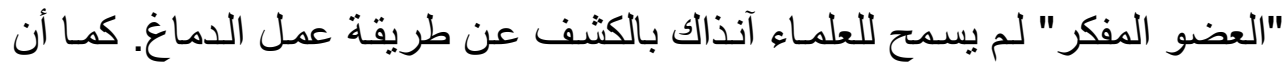
اتجاه التعلم المبني على الدماغ قد ظهر في الثمانينيات من القرن الماضي كمجال علمي جديد، وبحلول التسعينيات تفرع لعدة مجالات علمية. وتفسر نظرية التعلم المستند إلى الدماغ مفاهيم نفس- تربوية في غاية الأهميـة منها:

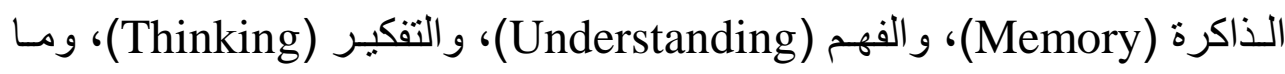
ور اء المعرفة (Metacognition) (Cercone, 2006). و هذا ما يؤكده جنسن (2006)؛ إذ أن هنالك ثورة في مجال البحوث الخاصة بالدماغ

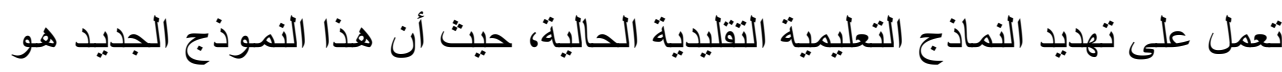

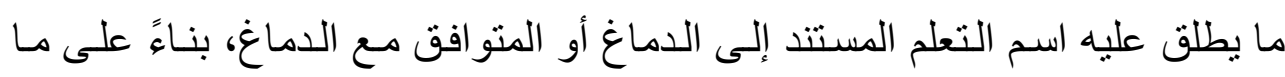
توصلت إليه الأبحاث الجارية في مجال العلوم العصبية لأفضل طرق التعلم الطبيعي

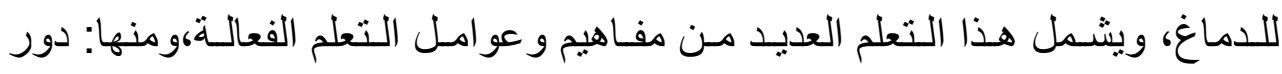

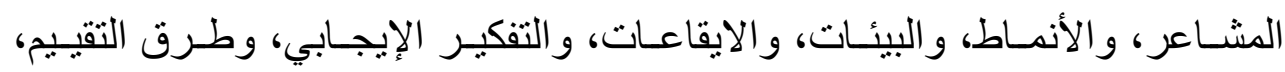

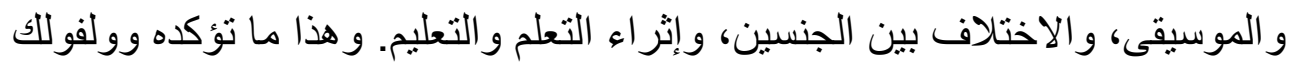


(2015) أيضاً في أن التعلم المستند إلى الدماغ يقدم بعض التوجهات للمربين الذين يسعون إلى تدريس أكثر غرضية (هدفية) ومستند إلى معلومات. و هذا مـا يؤكده الحـارثي (2001) كذلكفي أن تطبيقات نتائج الأبحـاث الحديثة في مجال الدماغ على عمليات التعلم تنذر بحدوث ثورة في مجال النظم التعليميـة، والتي قد تـؤدي إلىى تغييـر أوقـات الدر اسـة ونظمهـا وسياسـاتها وطـرق تقيـم التـدريس، و اسـتر اتيجياته، و البيئة التعليميـة، و اسـتعمالات تكنولوجيـا التعلـي. كذللك أكدنتنلي (2010) في أن عصراً من الاكتشافات يبزغ عبر البحث في الدماغ، واستناداً إلى نتائج أبحاث الدماغ خرجت إلى الوجود نظرية التعلم المستند إلى الدماغ التي تؤكد على أن لكل فرد حق في أن يمـارس عمليـة التعلم، لذلك من الضـرورة تخليق بيئة تعلم تعمل على استغراق المتعلم في الخبرة التربوية، وتخليص المتعلم من الخوف، و السماح له بالمعالجة النشطة.ولللك يؤكد جنسن (2015) أن المتعلم يتغير عندما يتم تحفيز دماغـه لتعلم أشياء جديدة، ومعقدة، ومليئة بالتحدي، و عندما يتعلم مهار ات جديـةة، أو المهـار ات التي تشــل العلاقـات بـين الأشـخاص. وهـذا مـا أكده سوسـا (2009) إذ أن الدماغ البشري يعد كياناً مثير اً للاهشة، فهو عـالم خـاص مليء بعدد غير محدود من القدرات الهائلة والأمور الخفية، وهو دائماً يتشكل ويعيد تشكيل نفسه نتيجة للخبر ات التي يمر بها، ولكنه لا يستطيع أيضـاً العمل معتمداً على نفسـه دون الحاجة إلى مدخلات من العالم الخارجي. وكما تثير سليم (2003 ب) أن التعلم هو أفضل نشاط يقوم به الدماغ البشري، حيث يغير التعلم الدماغ، لأن الدماغ يستطيع أن يعيد تتظيم نفسـه مـع كل خبرة وسلوك جديد، إذ أن هنالك مثير اً ما للاماغ يبدأ العملية، بعد ذلك يتم فرز أو تحديد المثير وتتم معالجته على عدة مستويات. إذ أن التعلم و التذكر وجهان لعملة واحدة بالنسبة لعلماء

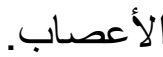
ويؤكد الزيات (1998) أن حجر الزاويـة لعلم النفس المعرفي الحديث هو الاعتقاد بأن الدماغ هو قاعدة العقل ومحوره الأساسي (The brain is the seat of the 
(mind) ومن ثم فإن الدماغ هو مناط السلوك الإنساني ومصدره حيث يؤثر ويتأثر بالمعرفة الإنسانية (Human cognition) باعتباره أساس النشاط العقلي المعرفي. من جهة أخرى؛ يعتبر موضوع تقدير الذات من الموضوعات المثيرة للجدل الكبير بين التربويين ومتخذي القرار، و تقضي المؤسسـات التربويـة كافـة وقتـاً كبير اً لتنمية

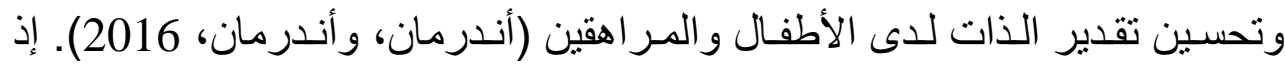
يتميز هذا العالم بالتنافس الثنديد والتغير السريع، ويمر الفرد بالكثير من الصعوبات من أجل الحفاظ على تقديره لذاته. وتقدير الذات يعني احتفاظ الفرد برأي عن نفسه، لهير، وأن التقدير المرتفع للذات هو حالة نفسية صحية، وهو من الموارد الداخلية التي لا تقدر بثن، و التي يحتاج الفرد لحمايتها وتتميتها (ليندفيلد، 2005 ب).

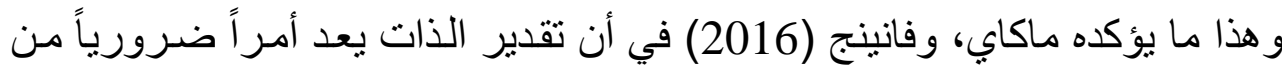
أجل سـلامة الفرد من الناحيـة النفسية، إضـافة إلى كونـه ضرورة عاطفية. فبدون

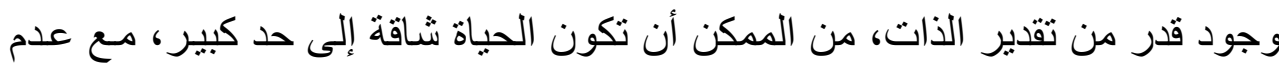
إثباع كثير من الحاجات الأساسية. ويشارك ميلر، وموران (Miller, \& Moran, 2012) هذه الفكرة بأن تقدير الذات له تأثير عميق على جميع جو انب الحياة؛ فهو يؤثر على مستوى أداء الفرد في الحياة

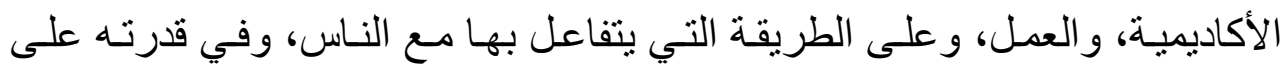
التأثير على الآخرين. وكذلك فإن تقدير الذات هو شرط أساسي من شروط السلوك المثمر والبناء بشكل عام. فأداء الفرد يكون أفضل في كل شيء يفعله عندما يعتبر نفسه أهلاً لأن ينجز ما بدأه، وجدير بالنجاح؛ ويشتعره في هذه الحالة بأنه ذو شـأن وأهمية.

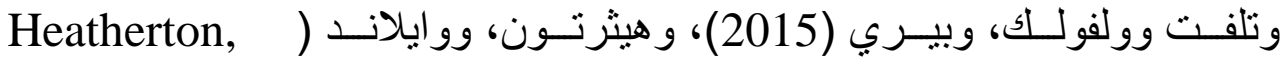
(\&Wyland, 2003 أو المعتقدات المعرفيـة (Cognitive beliefs) التي لدينا عن أنفسنا، فإن تقدير الذات يشير إلى القيمة التي نلصقها بهذه الصورة؛ إنه الجزء التقييمي الذاتي لدفهوم 
الذات ـ الحكم الذي يصدره الفرد عن قيمة الذات بشكل عـام -، وتشتق هذه الأحكام عادة من التغذية الر اجعة الواردة من الآخرين. وتؤكد وولفولك (2015) بأن تقدير الذات عبارة عن رد فعل وجداني وحكم تقييمي عن جدوى الذات، ويستخدم كل من مفهوم الذات، وتقدير الذات بديلاً عن بعضـهما البعض في غالبيـة الأحيان، على الرغم من أن لكل منهما معنى متمـايز اً؛ فمفهوم الذات هو تكوين معرفي، و اعتمـاد عما يكون الفرد، وأحيانـاً يعد تقدير الذات أحد مظاهر مفهوم الذات ـالمظهر التقييمي منـه. ويقسم لور انس (Lawrence, 2006) العو امل المؤثرة في تقدير الذات إلى؛ العوامل الخارجية وهي العوامل البيئيـة وتضـ البيئة الأسرية وتأثير الو الدين على الفرد، وتقييمات وآراء الآخرين المهمين في حياة الفرد، و المظهر الخارجي. و العوامل الداخلية؛ وهي العوامل التي يولدها الفرد نفسه؛ مثل أفكاره عن ذاته، وتطلعاته الثخصية، و إنجـازه الأكاديمي، وبر اعته في أداء

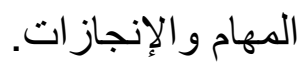
من جهة ثالثة؛ تشير مورينو (Moreno, 2010) إلى أن مفهوم أو مصطلح الدافع يستخدم لوصف العمليات النفسية التي تستحث الفرد وتوجه نشاطه، كما يستخدم هذا المفهوم بشكل عام لتفسير ما يدور داخل الفرد، ورلا يمكن ملاحظته بصورة مباشـرة، و إنما يمكن استتناجه و الاستدلال عليه كديناميات تحرك سلوك الفرد وتوجهه، و إذاً فإن الدافع يجمع بين وظيفتي استثارة السلوك وتوجيهه. ويكاد يكون هناك اتفاق بين علماء النفس التربوي على أهمية دور الدافعية في تحريك وتوجيـه السـوك الإنسـاني بصفة عامة، وفي التعليم و التحصيل الدر اسي والإنجاز الأكاديمي بصفة خاصة، ولذا فـإن موضـوع الدافعيـة يعتبر مـن أهم الموضـوعات المرتبطـة بـالتعلم والتي يجب تناو لها تناو لاً معمقاً. ويقول أندرمان، أندرمان (2016) أن قليل من التربويين والآباء يجادلون في الحاجة إلى تعزيز دافعيـة الطلبة، بينمـا لا يفهم العديد من الأفر اد تعقد الدافعيـة الأكاديميـة 
على نحو تام، ور غم معرفة معظم التربويين الكثير (Academic motivation) عن الدافعية الإنسانية، إلا أنه دائماً يمكن تعلم المزيد عنها.

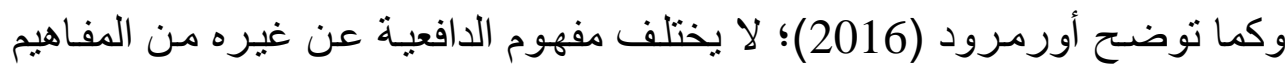
النفسية باعتبار أي منها تكوين فرضي (Hypothetical construct)، أي يفترض وجوده ويستدل عليه من خلال آثاره. ويمكن تعريف الدافع بأنه حالة شعورية أو حاجة أو حافز يقود أو يؤدي إلى القيام بسلوك ما، كما يمكن تعريفه بأنه مثير داخلي

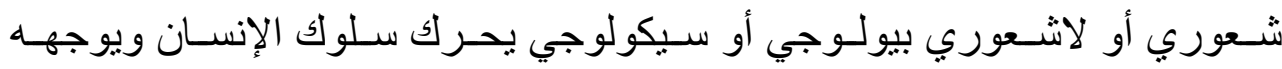

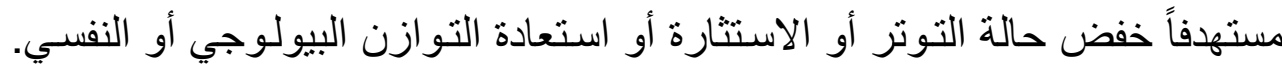

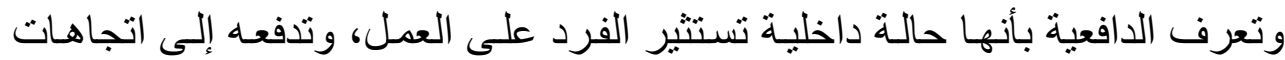
محددة وتبقيه مشتركاً في أنشطة معينة. ويشير خليفة (2000) إلى أن دافعية الإنجاز هي إحدى الجوانب المهمة في منظومة الدو افع الإنسانية، و التي اهتم بدر استها الباحثون في مجال علم النفس عامـة، ومجال علم النفس التربوي خاصة. ويرجع الاهتمام بدراسة الدافعية للإنجاز نظر أ لأهميتها ليس فقط في المجال النفسي، بل في العديد من المجالات و الميادين التطبيقية والعملية الأخرى، كالمجال الاقتصادي، والإداري، والتربوي، والأكاديمي، حيث يعد الدافع

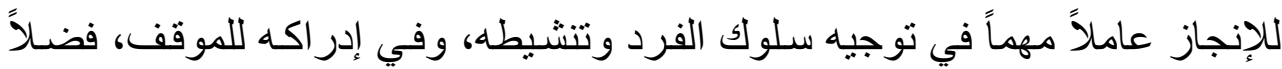
عن مساعدته في فهم وتفسير سلوكه، وسلوك المحيطين به.كما يعتبر الدافع للإنجاز مكوناً جوهرياً في سعي الفرد تجاه تحقيق ذاته، وتوكيدها، حيث يشعر الفرد بتحقيق ذاته من خلال ما ينجزه، وفيما يحققه من أهداف، وفيما يسعى إليه من أسلوب حياة

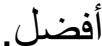
ويشير الرشيدي، وأبو علام، والجبر، و الهاجري (2004) إلى أن دافع الإنجاز هو التقدم نحو الهدف المر غوب، ويستخدم هذا المصطلح بصفة عامـة بمعنى الوصول إلى هدف، ويعني هذا الإنجاز مـا أحرزه الفرد وحصله في أثناء التعلم والتدريب

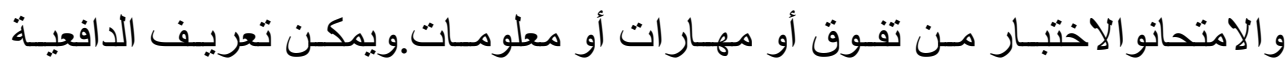


للإنجاز بأنها حاجة لدى الفرد للتظلب على العقبات، والنضال من أجل السيطرة على

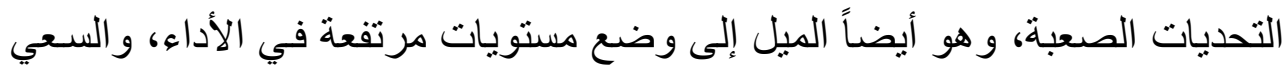

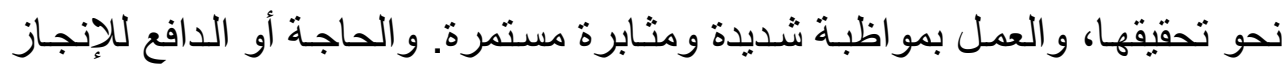

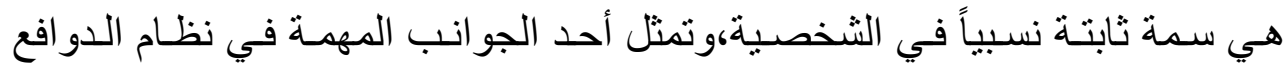

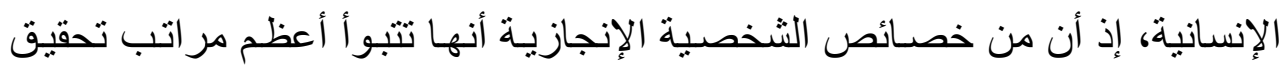

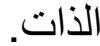

وتدعى الحاجة إلى الإنجاز أحياناً بالدافعية للإنجاز ، وهي حاجة للتميز في حد ذاتها

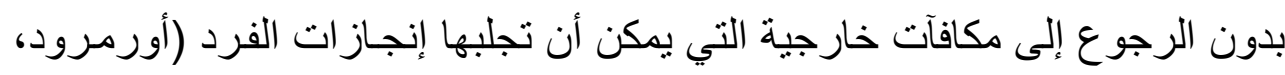
. (2016

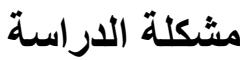

لاحظ الباحث من خلال عمله في سلك التدريس الجامعي الممتد عبر (17) عاماً؛ أن هناك ضـعفاً في مستوى تقدير الذات و الدافعيـة للإنجاز لدى طالبـات كليـة الأميرة

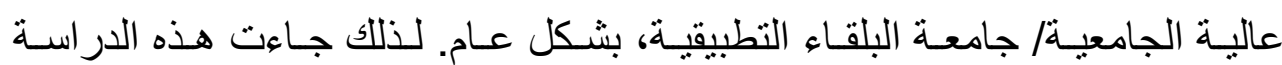
للمساهمة في اقتر اح حل لهذه المشكلة التي تؤثر بالضرورة على جو انب شخصية

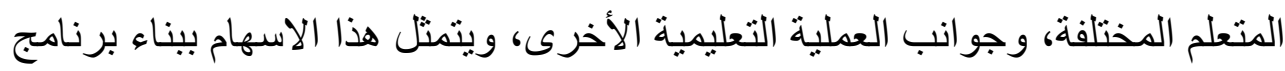

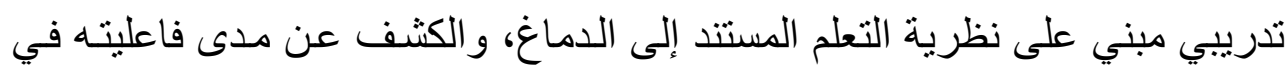

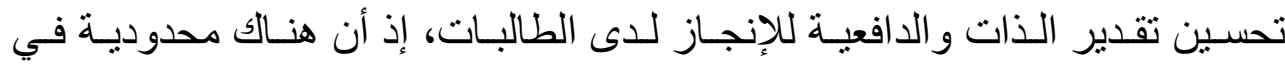
البر امج التدريية المبنية على مبادئ نظرية التعلم المسند إلى الدماغ الموجهة للطلبة بشكل عام، والطلبة الجامعيين بشكل خاص، وتحديد فعاليته على كل من تقدير الذات و الدافعية للإنجاز ، وذللك في حدود اطلاع الباحث. وتبلورت مشكلة الدر اسة من خلال مر اجعة الأدب التربوي و الدراسات المتعلقة بكل

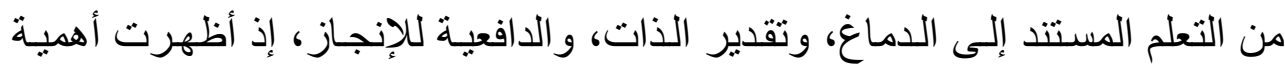
كبيرة على دراسة هذه المتغير ات المختلفة في البيئة الأردنيـة. من هنا تتحدد مشكلة

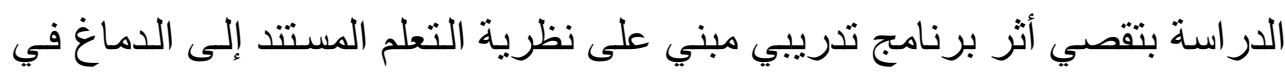


تحسين تقدير الذات والدافعيـة للإنجـاز لدى طالبـات كليـة الأميرة عاليـة الجامعيـة|

جامعة البلقاء التطبيقية.

فرضيات الدراسة

جاءت هذه الدر اسة بهدف تصميم برنـامج تدريبي مبني على نظريـة التعلم المستند إلى الدماغ في تحسين تقدير الذات و الدافعية للإنجاز. وبالتالي هدفت هذه الدر اسـة إلى الإجابة عن الفرضية الرئيسة الآتية: " هناكأثر للبرنامج التدريبي المقترح المبني على نظرية التعلم المستند إلى الدماغ في تحسين تقدير الذات والدافعيـة للإنجـاز لدى طالبـات كليـة الأميرة عاليـة الجامعيـة|

جامعة البلقاء التطبيقية". وينبثق عن هذه الفرضية الرئيسة الفرضيتين الآتيتين: 1.توجد فروق ذات دلالـة إحصـائية عند مسـتوى الدلالـة (a=a.05) بينالمجموعـة التجريية و المجموعة الضابطة فيتقدير الذات تعزى للبرنـامج التدريبي المبني على نظرية التعلم المستند إلى الدماغ، ولصالح أفر اد المجموعة التجريبية. 2.توجد فروق ذات دلالـة إحصـائية عند مسـتوى الدلالـة (a=a.05) بينالمجموعـة التجريبية و المجمو عة الضابطة في الدافعية للإنجاز تعزى للبرنـامج التدريبي المبني على نظرية التعلم المستند إلى الدماغ، ولصالح أفراد المجمو عة التجريبية. مبررات الاراسة

بمـا أن نظريـة التعلم المستند إلى الـماغ تأخذ مدى متز ايداً مـن الاهتمـام مـن قِبـل القائمين على العملية التعليمية بشكل عـام، و المعلم بشكل خـاص، ومـن خلال مسـح الباحث للار اسات حول موضوع هذه النظرية، لم يجد - في حدود علمه وبحثه ـ إلا عدداً محدوداً من الدر اسـات التي ربطت بين هذه النظريـة وتحسين مستوى تقدير الذات من جهة، ودر اسات أخرى ربطت بين هذه النظريـة وتحسين مستوى الدافعيـة للإنجاز مـن جهة أخرى. وهذا يعني ضـرورة اختبـار فعاليـة برنـامج تدريبي في تحسين كلاالمفهومين معاً. كذلك تجريب هذا البرنامج على عينة من طالبات الجامعة 
للوقوف على فعاليته لديهن، مما ينعكس بالضرورة على العمليـة التعليمبـة التعلميـة، ويعد إسهاماً تربوياً في هذا المجال. كذلك تعمل هذه الدراسـة، فيما بتعلق بموضوع التعلم المستتد إلى الدماغ على توجيـه المعلمين لضـرورة الاهتمـام بها وتوظيفها مـا أمكن في تفصيلات المشهد التعليمي التعلمي.

\section{أهمية الدراسـة}

جاءت هذه الدراسة لتكون من الدراسات الريادية التي تقوم بالكثف عن أثر برنـامج تدريبي مبني على نظرية التعلم المستند إلى الدماغ في تحسين تقدير الذات و الدافعية للإنجاز لاى طالبات كلية الأميرة عاليـة الجامعيـة/ جامعة البلقاء التطبيقية. وتتمثل أهمية هذه الدر اسة بما بأتي:

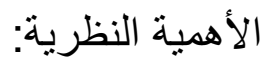
ـ تلقي هذه الدر اسة الضوء على الجوانب المتعددة لمفاهيم: التعلم المستند إلى الدماغ، وتقدير الذات، والدافعية للإنجاز ؛ مما يسهم في توفير المعلومات حول هذه المفاهيم؛ الأمر الذي قد يساعد الباحثين في هذه المجالات فيما بعد. ـ تأتي هذه الدراسة استجابة للتوجهات العالميـة ونتائج أبحاث الدماغ، والتي تتـادي بضرورة التغيير في المجال التعليمي؛ بما يتو افق ومبادئ عمل الدماغ، وبمـا يسـاعد على تنميـة تقدير الذات و الدافعيـة للإنجـاز ، و إحداث التكامل بين الجوانب الدافعيـة

$$
\text { و المعرفية و الشخصية للمتعلم. }
$$

ـ مو اكبـة الدر اسـة للتوجهات النفس-تربويـة الحديثة التي تؤكد على أهميـة تضمين مبـادئ عمـل الـدماغ في جميع النشـاطات المنهجيـة و اللامنهجيـة التي ينخرط بهـا الطالب.

ـ تأتي هذه الدراسة لمعرفة فاعلية برنامج تدريبي مبني على نظريـة التعلم المستتد إلى الدماغ في تحسين تقدير الذات والدافعيـة للإنجـاز، وهذه الدر اسـة تعتبر أولى الدراسات التي بحثت في هذا المجال، مما يعزز أصالتها. 


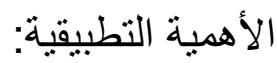
ـ ترجـع أهميـة الدر اسـة فـي أنهـا قـد تقيـد كـلاً من:أسـاتذة الجامعـات و المـدارس و المؤسسـات التربويـة؛ في اسـتخدام البرنـامج التـدريبي المبني على نظريـة التعلم المستند إلى الدماغ، لتحسين تقدير الذات، و الدافعية للإنجـاز ، وتضمين استر اتيجيات التدريس المتناغمـة معها في الخطط الدر اسية للمسـاقات الدر اسية الجامعيـة لتحقيق الهدف منها، ومخططي ومطوري المناهج الدراسية؛ في مر اعاة طبيعة عمل الدماغ، وتقديم أنشطة تتناسـب مـع التعلم المستند إلى الدماغ، لمختلف المر احل الدراسية، و الباحثين؛ في الاستفادة من البرنـامج المعد لأهداف هذه الدر اسـة، و المتعلمين؛ في تحسين تقدير هم لذاتهم، ودافعيتهم للإنجاز . ـ تقدم نتائج الدر اسـة دليلاً تجريبياً لإمكانيـة تحسين مستوى تقدير الذات، ودافعيـة الإنجاز عند الطلبة. ـ قد تشكل نتائج هذه الدر اسة استثارةً لمزيد من الدراسات التربوية لتطوير إجر اءات التعلم المستند إلى الدماغ؛ الأمر الذي قد يسـهم في تحسين وتطوير المفـاهيم ذات الصلة بالعملية التعليمية التعلمية.

أهداف الاراسة تهدف هذه الدراسة إلى: 1. التعرف إلـأثر برنـامج تدريبي مبني على نظريـة التعلم المستند إلى الدماغ في تحسين تقدير الذات والدافعيـة للإنجـاز لدى طالبـات كليـة الأميرة عاليـة الجامعيـة| جامعة البلقاء التطبيقية. 2. التعرف إلمدى وجود فروق ذات دلالة إحصـائية بين متوسطات رتب درجات أفر اد المجموعة التجريبية، ومتوسطات رتب درجات أفر اد المجموعـة الضـابطة في القياس البعدي لتقدير الذات والدافعية للإنجاز . 
3. التعرف إلى مدى وجود فروق ذات دلالة إحصائية بين متوسطات رتب درجات أفر اد المجموعة التجريبية في القياس القبلي، و القياس البعدي.

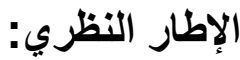

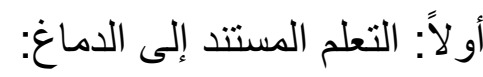
بداية؛ تورد كونيل (Connell, 2005) وسوسـا (Sousa, 2017) أنه في عام

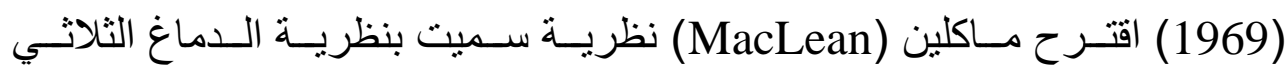

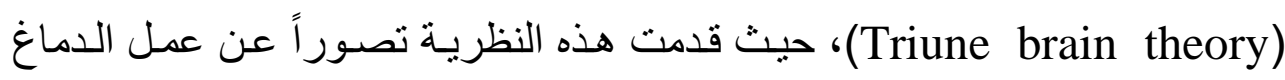
البشري (وكانت أولى المحاو لات العلمية التي تصدت إلى تقسيم الدماغ إلى مناطق

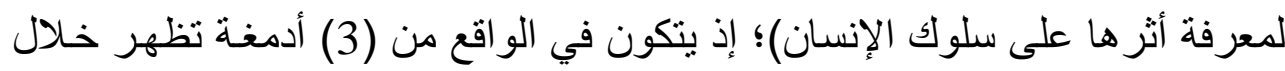

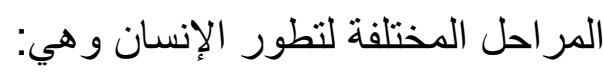
الدماغ البدائي (دماغ الزواحف) (The reptilian brain): وهو القهون القسم السفلي الذي يتكون من المخيخ و النخاع المستطيل، حيث يتحكم بـالغر ائز الأساسية، وهو الدماغ الأول بالتكون بالمقارنة مع الأدمغة الأخرى.

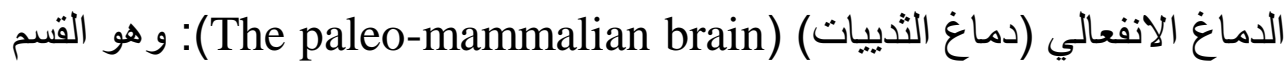
المتوسط الذي يتكون من الجهاز اللمبي (الحافي) (The limbic system)، حيث يتحكم بالانفعالات و السلوك و الذاكرة. الدماغ الففكر / المنطقي (The mammalian brain): وهو القسم الأعلى ويعتبر قسم الرئيسيات، الذي يتكون من القشرة الدماغية (Neocortex)، وهو المسؤول عن التفكير والفهر وأوامر الحركة. وبعد ذلك؛ يشير الريماوي، و الزعبي (2014) أن المعلومات التي تم التوصل إليها

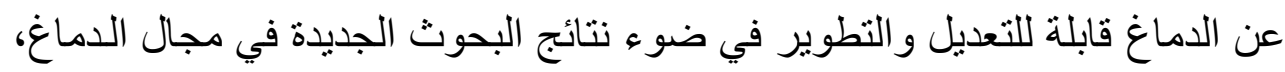

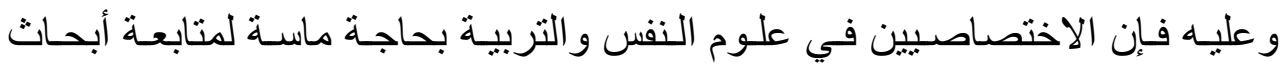

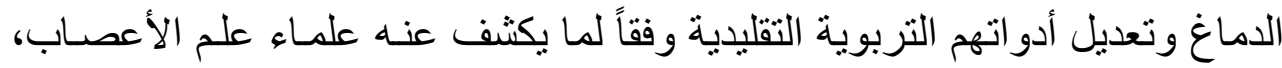
إذ أن التعليم التقليدي غالباً ما يقمع التعلم بعدم تشجيعه أو تجاهله، أو معاقبته عمليات 
التعلم الطبيعيـة للـدماغ. وتضـيف ميلـر (2011) أن الأبحـاث في علم الأعصـاب

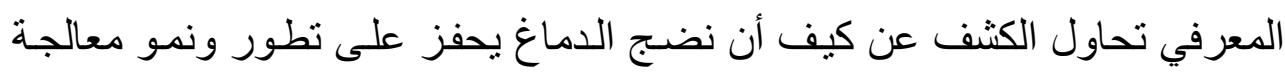

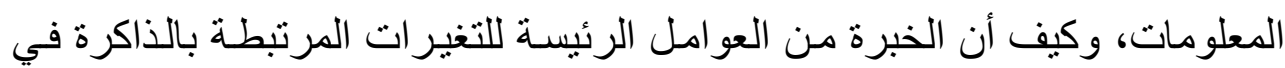
الدماغ، إذ يعيد الدماغ تنظيم نفسه باستمر اره.

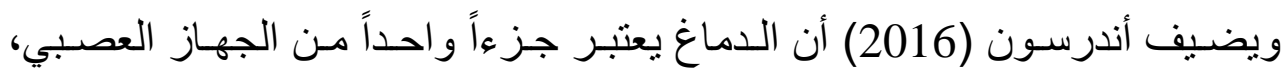

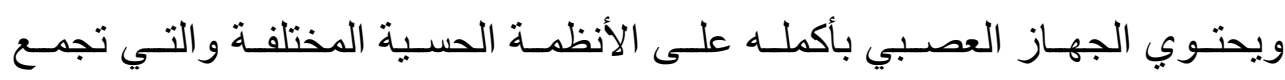
المعلومات من أجزاء الجسم، والأنظمـة أو الأجهزة الحركية التي تتحكم بالحركة.

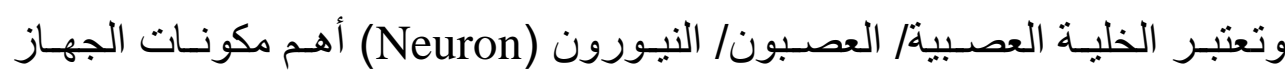

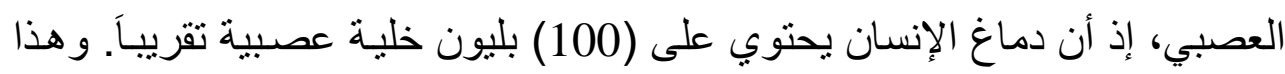

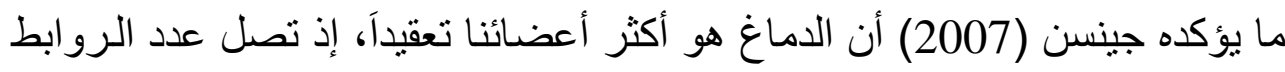

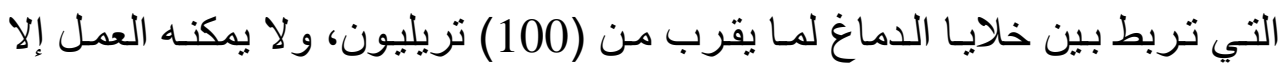
بصورة متعددة ومتثـعبة، فهو طوال الوقت يسجل التصسورات (أكثر من 3600

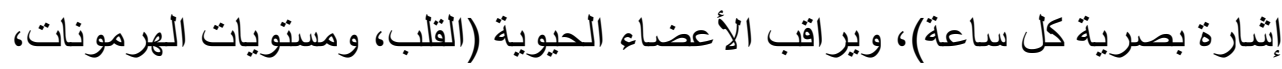
و التنفس، والهضم، ...الخ)، ويستمر في تحديث مفهوم الفرد عن الو اقع (مطابقة التعلم الجديد مع تصور ات الماضي)، و علاوة على ذللك، فالدماغ يربط الانفعالات

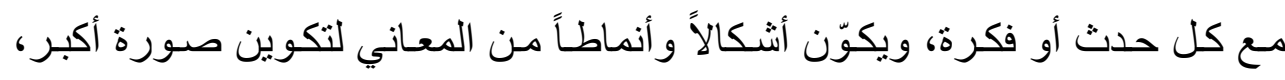
ويقوم باستنباط الاستتناجات عن المعلومات التي حصل عليها. وقد أثنبت العلمـاء أن

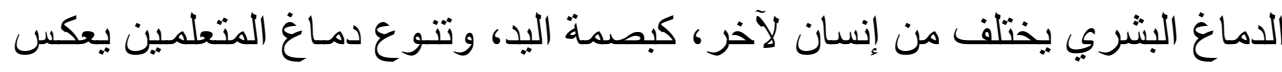
العديد من العوامل التي تشمل التأثيرات الور اثثية والبيئية. ويتكون الترابط بين بين الخلايا

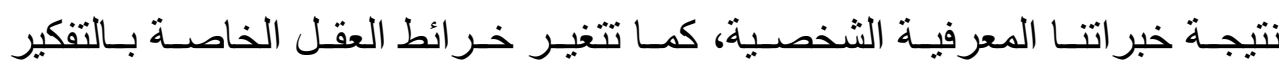
والإدر الك والاحتفاظ بالمعلومات باستمر ار، وتظهر التذبذب الكبير في حدود قدراتنا مع مرور الوقت. ويشترك كل من إيجلمان (2013)، وشنك (Schunk, 2012)،و غرينفيلد (2010)،

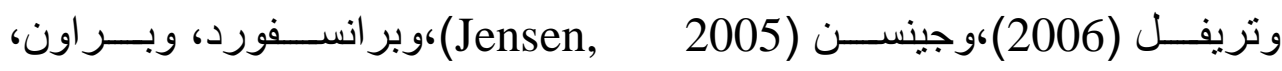


وكوكينج(Bransford, Brown, \& Cocking, 2000في أن الدماغ يتكون من Glial ( البلايين من العصبونات (Neurons)،و الدبق العصبي (الخلايـا الدبقيـة) (cells نبضات كهربائية إلى الخلايا الأخرى، تصل إلى المئات في الثانية الواحدة. وتتر ابط

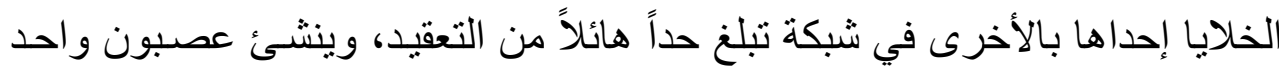

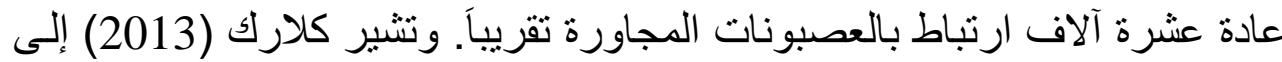

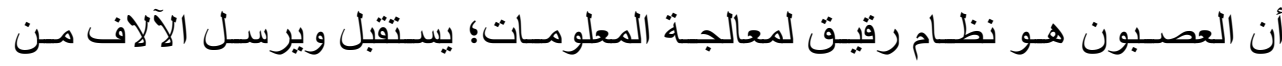
الإشارات، و لا تتشابه به أب خلية مع أخرى، ولا أي دماغ مـع الآخر ـ وتبسط تمبل

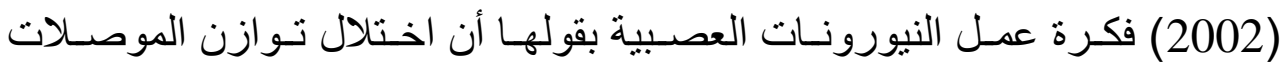
العصبية (الكيمبائية) أو نضوبها، يمكن أن يؤدي إلى صعوبة السيطرة على التفكير

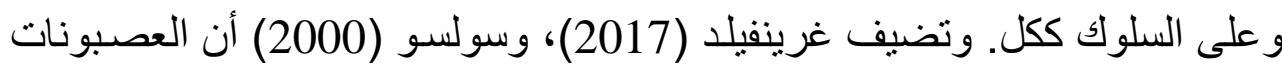

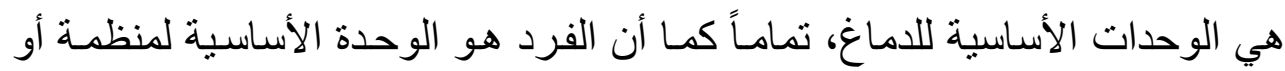

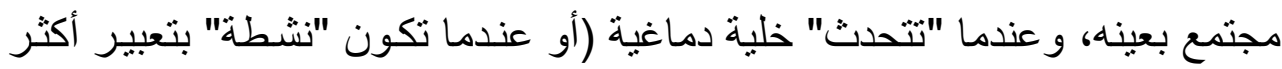
تقنية)؛ فهي تولِّد ومضة كهربية صغيرة تدوم جز عاً من الألف من الثانية (واحد مللي

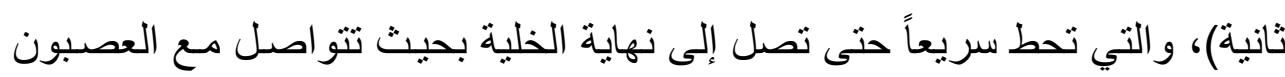

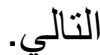
ويشير إسبيتان (2009)، وتريفل (2006)،وجينسن (Jensen, 2005)، وسولسو

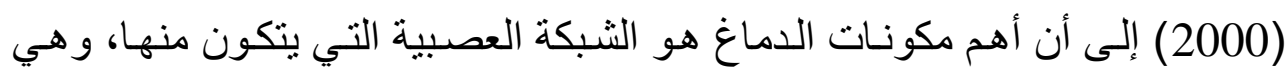
عبارة عن شبكة عصبية معقدة، ومتر ابطة، ويوجد لهذه الثبكة العصبية المعقدة مجمو عة من الخصائص المهمة، والتي تسمح بظهور نشـاطات وآليات عمل داخل الدماغ وممارسة نشاطات ذهنية معقدة، منها: 1. التعميم: وتتمثل في عملية تثكيل مبادئ عامة أو استتناجات من مجموعة من الحقائق المنفصلة، أو من خلال الخبرة و التعلم و الأمثلة. 


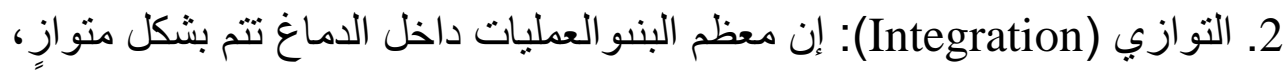
وتعمل معاً، وفي نفس الوقت. 3. التعلم: القدرة على تعلم الحقائق و اكتساب المعرفة. 4. الترتيب الذاتي: القدرة على تنظيم العمليات وترتيب نفسها دون الحاجة إلى تدخل خارجي، و هذا بشمل عملية توزيع المعرفة وتصنيفها، وتبويبها، وترتيبها، وبناء آلية اللوصول إليها. 5. التكيف (Adaptability): هي القدرة على التكيف مع البيئة الداخلية و الخارجية من خلال التعلم و التغير لتحقيق أهدافها.

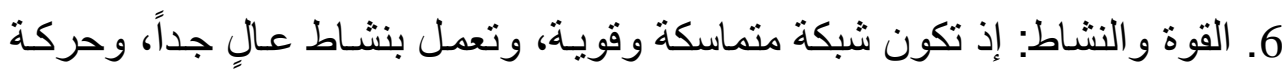

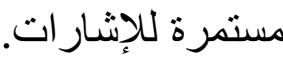

7. تجاوز الأخطاء: حيث أن هذه الثبكة لا تسمح بانهيار النظام نتيجة حصول خطأ

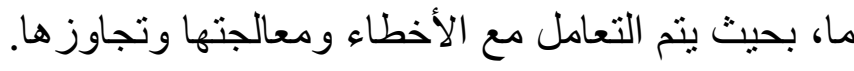
8. مكونة من مجمو عات صغيرة منصلة: وهي عبارة عن الوحدة الأساسية للبنية، ألا و هي الخلايا العصبية المرتبطة بشكل قوي ومتماسك.

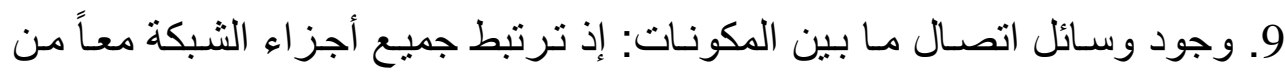

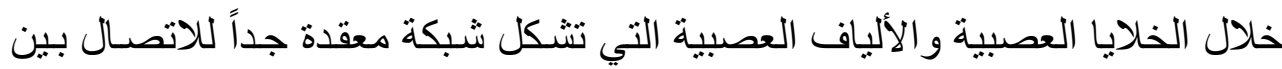

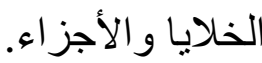
10. التعلم مـن الأمثلـة: أحد أهم قدرات التعلم لديها هو من خـلال مجموعـة مـن الأمثلة، حيث تتثكل على شكل مبادئ وآليات عمل ومعالجة تتطور إلى محركات التهات وكينونات افتراضية. 11. مستوى عالٍ من التعقيد نتيجة للتركيبة (Sophistication): إذ يعتبر الدماغ غاية في التعقيد، وذلك لوجود عدد كبير من وحدات البنية، و الربط بينهاهمهـ يثكل شبكة معقدة جداً تربط بين الأجزاء. 
12. حفظ البيانات أو التذكر : لدى الثبكة قدرة عالبـة جداً على تخزين المعلومـات وبأثــكال مختلفـة؛ مـن خـلال تحويـل عمليـة الـتعلم إلـى تخـزين لعمليـة التـذكر

$$
\text { و الاسترجاع. }
$$

13. قدرات خاصة: استخدام المعلومات خلال رد الفعل، مع احتمال لضياع البيانـات لأسباب متنو عة.

ويوضـح جينسن (2007) مر احل التعلم حسب نظريـة التعلم المستند إلى الدماغ؛ إذ يحدث التعلم المثالي في تتابع يمكن توقعه، ويشمل خمس مر احل هي كالآتي: 1.الإعداد (Preparation) أو التعرض المسبق للمعلومات: و التي توفر إطار آ مبدئياً للتعلم الجديد، ويحفز دمـاغ المتعلم بالتر ابطـات الممكنة، وهذه المرحلة (Frame) تشمل إلقاء نظرة عامة على الموضوع، وتقديماً بصرياً للموضوعات المرتبطة بـه، وكلمـاز ادت خلفيـة المـتعلم عـن الموضــــ عـ ازدادت سـر عة اسـتيعابه للمعلومـات الجديدة.

2.اكتساب المعلومات (Acquisition): ويمكن تحقيقها من خـلال الطرق المباثرة مثنل توفير الأوراق والملخصـات للطلبـة، أو طرق غير مباثـرة مثنل وضـع أدوات بصرية متعلقة بموضـوع التعلم، وكلا الطريقتين تنجحسان، وهمـا تكمـلان بعضـهما البعض. و التعريف العصبي للاكتسـاب هو تكوين الترابطات بين الخلايـا العصبية، وبالتـالي فـإن مرحلـة الاكتشـاب هـي تكوين الرووابط أو "حديث" الخلايـا العصبية لبعضـها البعض. ومصـادر الاكتسـاب و اسـعة، وقد تشــل: المناقتــة، و المحاضـرة، و الأدوات البصـرية، و المثيـرات البيأيـة، و التجــارب العلميـة، و التمثيـل، و القـر اءة، و الأدوات اليدوية، والتأمل، و المشرو عات الجماعية، والأنشطة الثنائية. 3.الثـر ح أو الإيضـاح/الإســهاب (Elaboration): وهـي تستكثـف التـر ابط بـين الموضـوعات وتشـجع على التفكير العميق.إذ أن التر ابط العصبي قد يحدث بثكل مؤقت ثم يضيع. وللتأكد من أن الدماغ يحافظ على تلك التر ابطات العصبية التي حدثت مـن التعلم الجديد، فمـن الضـروري وجـود الإيضـاح الإضـافي للتأكيد على 
المعلومات. إن طرق التعلم المباشرة و الضمنية مفيدة في مرحلة الإيضـاح، كمـا أن الإيضاح يعطي الدماغ الفرصة لفرز وتحليل واختبار وتعميق التعلم. 4.تكوين الذاكرة (Memory formation)، و الربط بين الأجز اء التي تم تعلمها

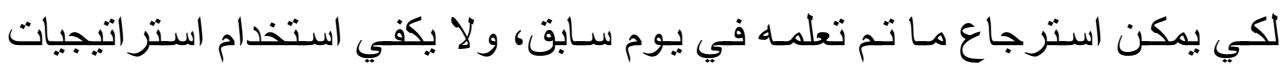

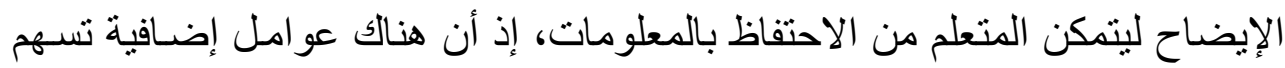

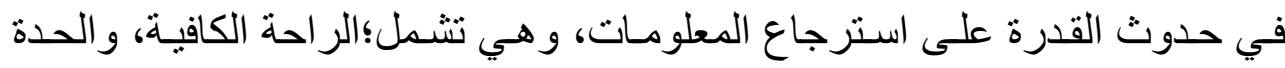
الانفعالية، والسياق، والتغذية، ودرجة وكم الترابطات، ومرحلة التطور التي يكون

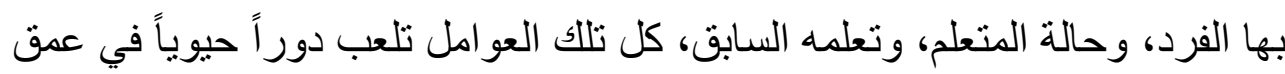

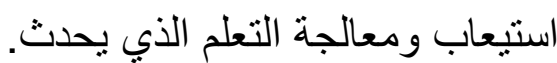

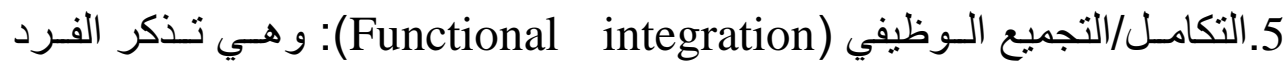
باستخدام التعلم الجديد لكي يتم تعزيزه أكثر وتوسيعه، والإضـافة إليه، بمعنى أنه

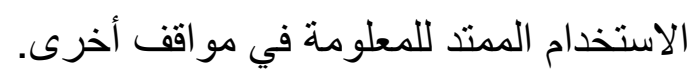
و لا تختلف المر احل المقترحة من هارديمن (2013) عن مر احل جينسن (Jensen)

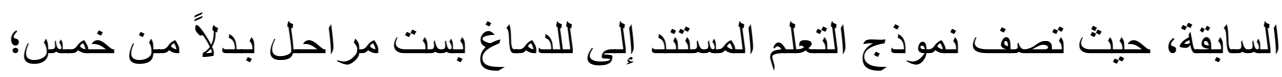
إذ تعتبر متر ابطة بطريقة عضوية، وتتضمن مكونات النموذج المر احل الآتية:

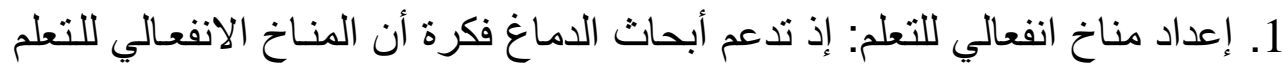
يمهذ الطريق لمستويات عليا من التعلم و الأداء، و العكس صحيح. 2. نهيئة بيئة التعلم المادية: إذ من الضرورة إضفاء عنصر الجدة من خلال تعديل

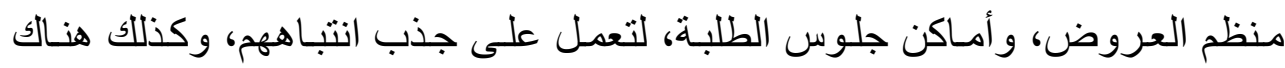
أهمية بالغة للإضاءة و الصوت و والروائح في التأثير على المتعلم.

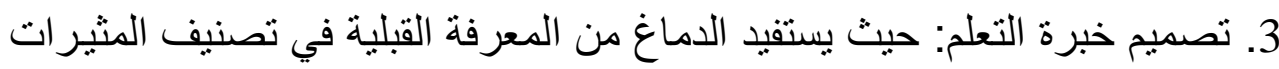

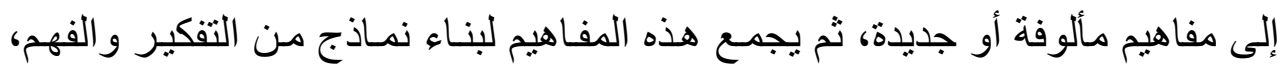
بالإضافة إلى استخدام خر ائط المفاهيم لإعطاء المتعلمين صورة أكبر عن الأفكار، أو فهم كلي للمفاهيم، بالإضافة إلى ربط هذه الأفكار بإدر اكهم ومعرفتهم القبلية. 
4. تـدريس المعرفـة الاجر ائيسة والتقريريـة: وفي هـذه المرحلـة يـتم التركيـز على العمليات التي يستخدمها الدماغ لاكتساب وتخزين المعلومات. 5. التعلم من أجل التوسع وتطبيق المعرفة: إذ تؤكد على استخدام استر اتيجيات التعلم التي توسع وتتقح تعلم الطلبـة، وتشـع الاستخدام ذي المعنى للمعرفة المكتسبة في حل مشكلات حياتية فعلية. 6. تقييم التعلم: إذ يعد التقييم جزءعاً مههـاً لعملية التعلم كأنشطة التعلم ذي المعنى، ويتضمن ذلك تزويد المتعلمين بتغذية راجعة فورية ومستمرة وذات صلة بأدائهم. ويصف جينسن (2007) البيئة المثالية للتعلم استناداً إلى منحى التعلم المستند إلى الـدماغ؛ إذ مـن الضـرورة أن تتضــن: البيئـة النفسـية المناسـبة، والبيئـة البصـرية الجذابة، و استخدام الألوان في البيئة، والصور المجسمة الحيـة، والأجهزة و الأدوات، والاستفادة من الضوء في البيئة، ومر اعـاة تأثنير فصول السنة على التعلم، ودرجة الحرارة المثالية للتعلم، وتجنب الجفاف إذيعمل على إعاقة التعلم، وتوفير النباتات، و الأخذ بعين الاعتبار تأثثر الروائح على الانتباه والتعلم، وتأثير التأين السلبي، وتأثير الموسيقى. ويضـيف الحسارثي (2001) إلى مكونـات البيئة الغنيـة التي تحفز عمل الدماغ؛التحدي العقلي؛ ويعني تضمين المـادة الدر اسية الجديدة درجة من الصـعوبة تزيد على صـعوبة المـادة التي تم تعلمها سـابقاً، ويمكن أن تكون درجـة الصـوبة الجديدة في نوع المادة أو في مستوى النواتج التعليمية المتوقعة أو في عامل الزمن، أو في طريقة التعلم. و الجدة أو الحداثة؛ وذلك بعرض أسلوب جديد أو مواد جديدة أو أفكار جديدة. وتغيير استر اتيجيات التعليم واستخدام استر اتيجيات جديدة مثل؛ العمل ضمن مجمو عات، أو الرحلات الميدانية، أو استضافة خبراء من الخـارج، أو التعلم من خلال اللعب، أو التعلم من خلال المشروعات، أو استخدام الحاسوب والإنترنت. و هذا ما يؤكده سوسا (Sousa, 2017) في أن المعلمين (وهم ليسوا علمـاء أعصـاب بطبيعة الحال) يحاولون كل يوم تغيير دماغ المتعلم باستخدامهح طرق و استر اتيجيات مختلفة عند تناول أي خبرة تدريسية في ضوء مـا توصل إليهه علمـاء الأعصـاب من 
حقائق ومعلومات عميقة عن طبيعة عمل الدماغ، سو اء كان التعامل مـع الطالب يتم في الغرفة الصفية أو في المدرسة، وهم القادرون فقط (أي المعلمون) على إحداث مثل هذا التغيير.

Caine, \& Caine,McClintic, ) ويورد كين، وكين، وماكلينتيك، وكليميك

12 Brain/ Mind ( المبـادئ الاثتـا عشـرة لتعلم الـدماغ وKlimek2005 Natural Learning Principles

1. كل التعلم يسـتخدم فسـيولوجية الجسـم ( All learning engages the .(physiology

2. الدماغ/ العقل اجتماعي (The Brain/ mind is social). 3. البحث عن المعنى فطري (The search for meaning is innate). 4. البحث عن المعنى يتم من خلال التتميط The search for meaning occurs) .(through patterning 5motions are critical to ) الانفعـالات بالغـة الأهميـة مـن أجل التنمبيط .(patterning 6. بعالجالـدماغ/ العقل الأجـز اء و الكـل بشـكل متززامن ( brain/ mind .(processing partsand wholes simultaneously 7. يتضمن التعلم كلاً من الانتباه المركز و الإدر الك الطرفي ( Learning involves .(both focused attention and peripheral perception 8earning is both ) يتضـمن التعلم عمليـات و اعيـة و عمليـات لا واعيـة (conscious and unconscious 9. لـدينا على الأقل طريقتـان لتنظيم الذاكرة ( They are at least two .(approaches to memory 10. التعلم تطوري (Learning is developmental). 


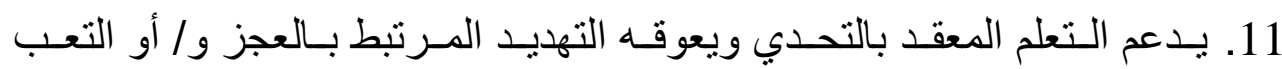
Complex learning is enhanced by challenge and inhibited by ) .(threat associated with helplessness and/ or fatigue 12. كل دماغ منظم بطريقة فريدة (Every Brain is uniquely organized). ويـورد سوسـا (2009) بعض الإنجاز ات التي حققها البحث الحديث حول الدماغ ورنها:

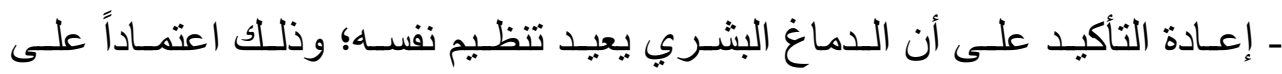
المـدخلات التي يسـتمدها مـن العـالم الخـارجي، وتعرف هذه العمليـة باسـم (مرونـة الخلايا العصبية) (Neuroplasticity) ويستمر الدماغ في القيام بهذه العملية طوال فترة حياة الإنسان، إلا أنها تكون سريعة بشكل غير مسبوق في السنوات الأولى من عمر الإنسان.

ـ توضيح المزيد من المعلومات حول قدرة الدماغ على اكتساب اللغة. ـ تطوير بعض بر امج الحاسوب التي لها أساس علمي، بحيث تسـاعد الأطفال بشكل كبير في التغلب على مشكلات القراءة. ــ توضـيح مـدى تـأثير انفعـالات الفـرد علـى عمليـة الـتعلم والـذاكرة واسـترجاع المعلومات. ــ الإشـارة إلى أن الحركة وممارسـة التمـارين تسـاعدان في تحسين الحالة المز اجية للفرد وزيادة كتلة الدماغ ودعم المعالجة المعرفية التي يقوم بها. ـ تتبع نمو وتطور دماغ الفرد في مرحلة المراهقة، وذلك من أجل الوصول إلى فهم أفضل للسلوك غير المتوقع عند الأفراد في فترة المراهقة. ـ فهم الإيقاع اليومي لأنشطة الجسم بشكل أفضل، وذلك لتفسير السبب وراء صعوبة عمليتي التعلم والتعليم في أوقات معينة من اليوم. 
ـ در اسة مدى تأثير عدم الحصـول على فترات كافية من النوم و الثـعور بالإجهاد على عملية التعلم و عمل الذاكرة. وتورد كلارك (2013) الخطوات السبع التالية في عملية التعلم و التعليم، وهي مبنية على نتائج الأبحاث التي أجريت على الصفوف التي تبنت أبحاث الدماغ في عملية

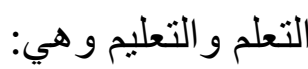

1. فهم وتطور الدماغ كأسـاس للتعلم Understand brain development as) the basis for learning)

2. إيجاد بيئة تعلم مستجيبة (Create a responsive learning environment) مادياً، واجتماعياً، وانفعالياً، وتعليمياً، أي أنها مرنـة وتلبي حاجـات الطلبـة، وتسمح لهم بالتعلم كل حسب سر عته الخاصة. 3. التكامل بين العمليات الذهنيـة Integrate the intellectual process: The integrative education model (IEM)) استر اتيجيات وممارسـات يمكن استخدامها في أي غرفـة صفية، حيث أنه بيستخدم التر ابط بين وظائف الدماغ الانفعالية و المعرفيـة والماديـة و الحدسية، وتسـح للمتعلم بأن يكون كفؤً وفعالاً بسبب استخدامه لجميع الأنظمة التي تدعم التعلم. 4. تأسيس تعلم مستمر (Establish the continuum of learning) و هو تضمين المعلم في خطته معايير وأهداف ومو اد لمستويات متعددة تناسب الطلبة الذي يقوم

$$
\text { بتدريسهم. }
$$

5. تقييم مستوى إتقان الطالب (Assess the student's level of mastery) وتعني تقييم مستوى الفهم والقدرات التي أتقنها كل طالب، بعد الانتهاء من تحديد

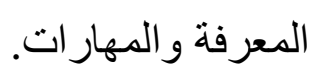

6. تعزيز وتمايز التعلم و التعليم Differentiate and individualize teaching .and learning) 7. تقييم التعلم و التعليم: وتضمن عملية المر اجعة والتطوير. 
وتــورد أورمــود (2016)، وكـلارك (2013)، والعتــوم، و الجــراح، و الحمــوري

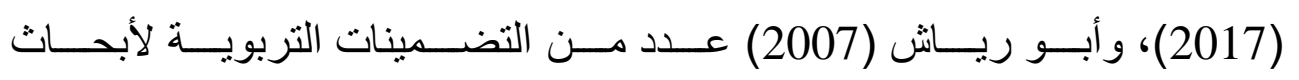

الدماغ(2017) (Educational implications of brain research)، المبنية على نت نتائج

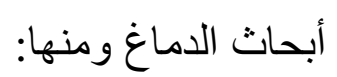

- يعتمد تطور الذكاء على التفاعل الموروث البيولوجي، والفرص البيئية التي تساعد على استخدام هذه الموروثات.

ـ الانتباه و التركيز يعتمد على أثر البيئة في الدماغ.

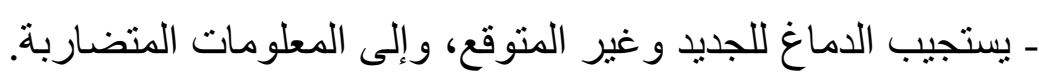

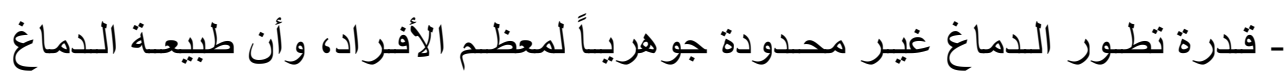

الديناميكية تسمح للتطور المعرفي بالتقدم أو التراجع و لا تبقى ثابتة. - يدمج الدماغ المعلومات ويبني الذاكرة و التنبؤات ويعمم النماذج على الحقيقة. ـ الدماغ لا يعالج فقط المعلومات أو يكبر الفكرة، ولكنه يبني معنى. - يلصق الدماغ معنى انفعالي للمعلومة.

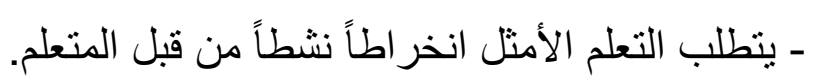
ـ التعلم بحتاج لفترات تعلم قصيرة. ـ التعلم يتأثر بالسياق الثقافي و الاجتماعي. ـ التعلم عملية بنائية تسهل بتنشيط معالجة المواد و الأفكار. - طبيعة وكمية التعلم برتبط بالحالة الانفعالية للمتعلم. - يزيد تركيز المعلومات بتعدد طرق إدخالها. - إنشاء معرفة جديدة يبدأ بتنشيط المعرفة السابقة. ـ السنوات الأولى مهمة للتعلم وكذللك السنوات اللاحقة. - جميع الأفر اد يستخدمون الجانبين من الدماغ في أدائهم للعمليات العقلية، إذ يعمل نصفي الدماغ في تعاون وثيق مع كل مهمات التفكير و التعلم. 
- يجب التقليل من الخوف و التهديد و القلق و الضغط في بيئة التعلم، و أن لا يسمح لهذه العو امل بإرهاق عملية التعلم. - التب - يجب تضمين المو اقف التعلمية قضايا و اقعية حقيقية يواجهها الطلبة. - تساعدنا أبحاث الدماغ في صقل نظرياتنا عن التعلم و الإدر الك. ويقترح شنك (Schunk, 2012)،و الزغول (2006) مجمو عة من الأفكار للعاملين في المجال التربوي تستند إلى نظرية التعلم المستند إلى الدماغ، ومنها:

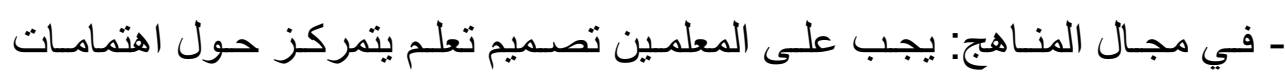
المتعلم، وجعل التعلم ضمن سياق (Contextual) .

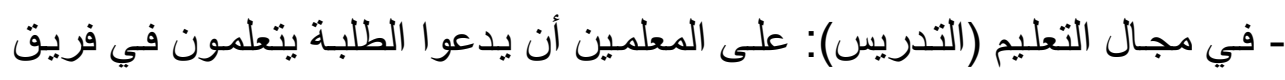

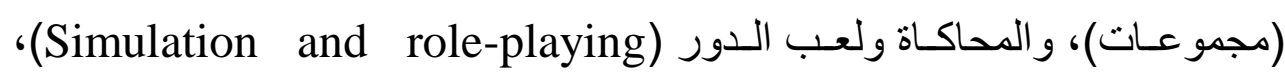

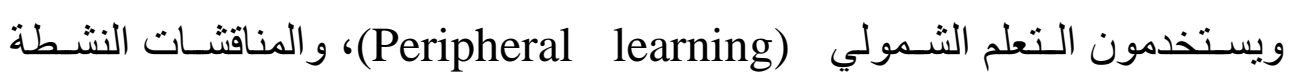

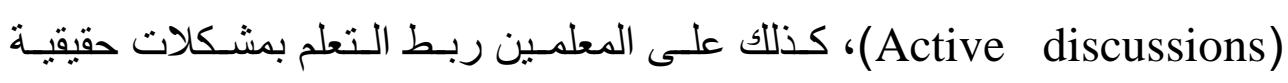

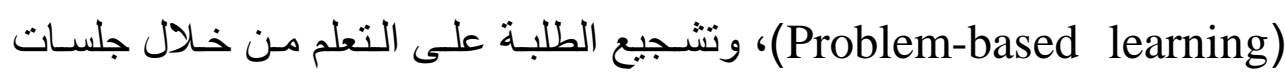
خارج الغرفة الصفية وخارج البناء المدرسي. - في مجال التقييم، بما أن جميع الطلبة يتعلمون، فإن تقييمهم يجب أن يسمح لهم بفهرم أساليب تعلمهم وتفضيلاتهم، مما يتيح لهم المر اقبة وتطوير عمليات تعلمهر. ثانياً: تقدير الذات:

يشير مالهي، وريزنر (2006) إلى أن هناك مكونين أساسيين التقدير الذات هـا:

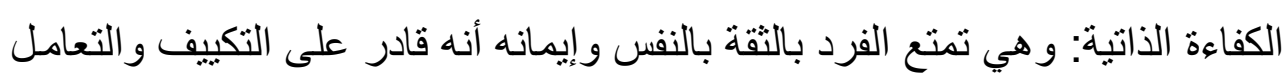

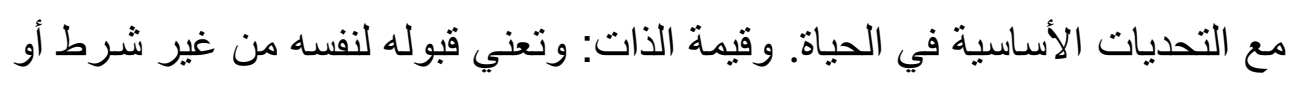

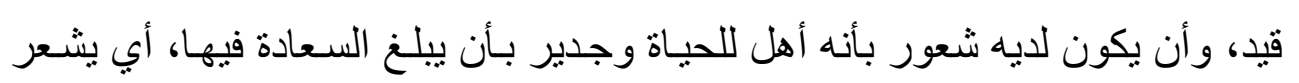

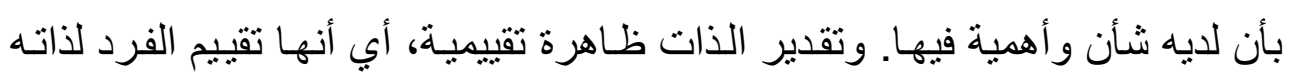

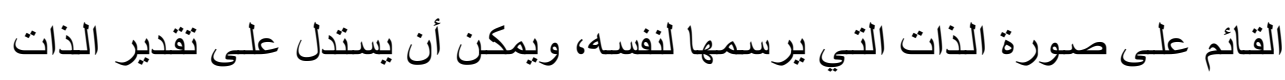
بالطريقة التي يتصرف بها الفرد. وتقدير الذات سمة متغيرة تكون دائهـاً خاضعة لفئل 
للتأثير ات الداخلية و الخارجية؛؛ فتقدير الذات يتبـاين تبعاً للمو اقف و الوقت، وأيضـاً تقدير الذات يمكن أن يتنوع يومياً تبعاً للتجارب و المشاعر الطيبة أو السيئة، ويمكن اكتساب وتعزيز تقدير الذات بمرور الوقت.

ويشير ميلر، وموران (Miller, \& Moran, 2012) ولور انس ( Lawrence,

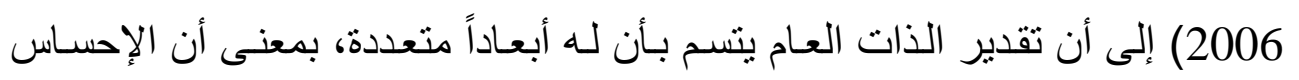

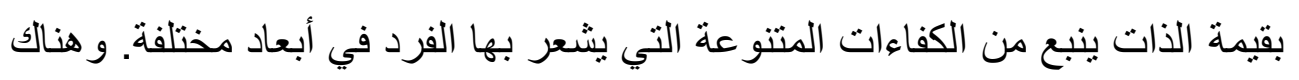

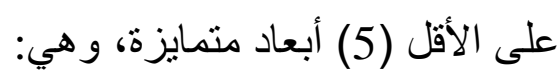

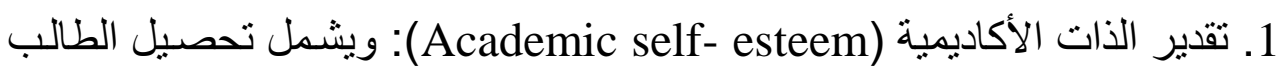
في المدرسة؛ منذ الصفوف الأولى وحتى نهاية المرحلة الثانوية، والجامعة.

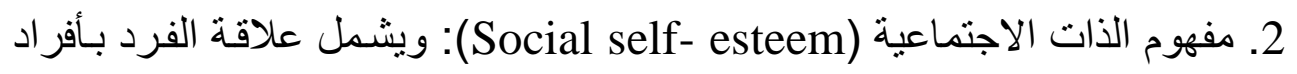
أسرنه، و علاقته بالأفر اد المهمين في حياته.

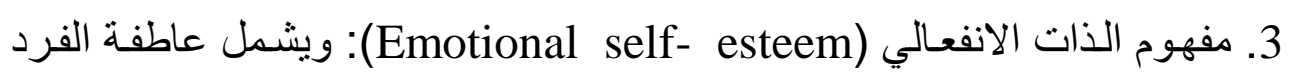
و انفعالاته تجاه الأشياء و الأفر اد من حوله.

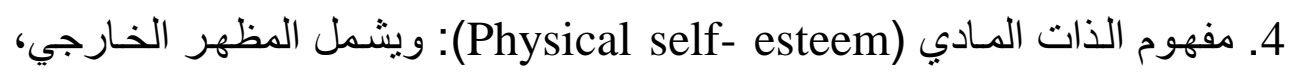
و القدرات البدنية؛ أي البناء الجسدي للفرد. و البعد الثـامل أو العام لتقدير الذات يستلزم إدراه الك الفرد الكلي لكفاءة وقيمة ذاتها، وهو مجموع الأبعاد النوعية والتفصيلية لتقدير الذات. فالتقدير العام للذات هو الكيفية

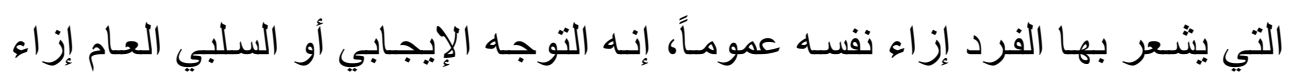

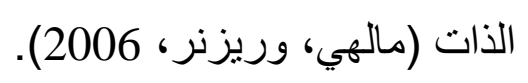
وتثثير ليندنفيلد (2005 أ) إلى أن تقدير الذات يبدأ في النمو والتطور بمجرد أن يبدأ

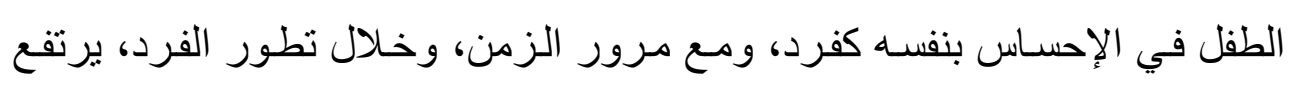

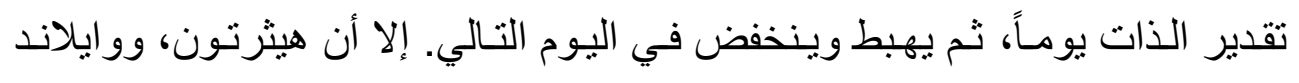
يشيران إلى أن بعض نظريات تقدير الذات (Heatherton, \&Wyland, 2003) ترى أنها سمة ثابتة/مستقرة نسبياً، بسبب أن هذا المفهوم يبنى بشكل بطيء عبر إن بعض نطرئ 
مراحل العمر المختلفة عن طريق الخبرات الثخصية (Personal experiences) التي يمر بها الفرد. - مان. و هذا مـا تؤكده وولفوللك، وبيري (2015) أن تقدير الذات يختلف حسب المرحلة

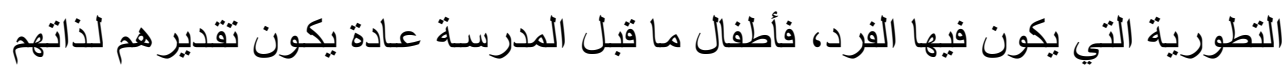

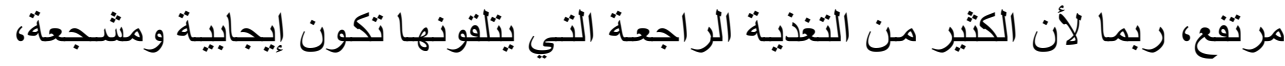

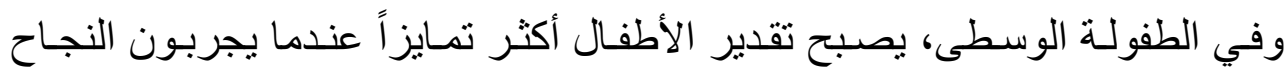

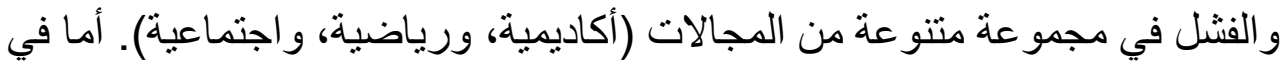
المر اهقة فإن الاعتبار الإيجابي للذات يقي الثباب من النتائج السلبية، مثل الفثل الدراسي، و التسرب من المدرسة، و الجنوح. وكما قد تم ذكره فإن مفهوم تقدير الذات الات التهن

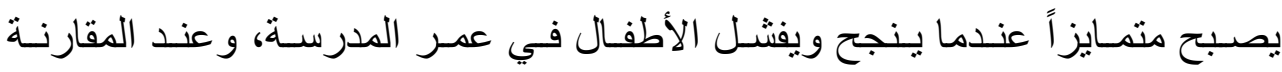
بالأقران، ويستمر هذا التمايز خـلال المر اهقة عندما يميل الثباب إلى الإثـارة إلى الى الفروق في تقدير هم لذو اتهم عبر سياقات علاقيـة (مثل: مـع الو الدين، و المعلمين،

$$
\text { وزملاء الدراسة). }
$$

ويمكن للتغذيـة الر اجعـة التـي يقدمها المعلمون، وأسـاليب وضـع تقديرات الطلبـة، وتقييمهم، وإحساس الطلبة بالر عاية من معلميهم، أن تحدث فرقاً فيما يتعلق بكيفية ولتهية

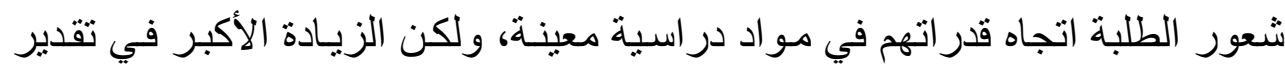

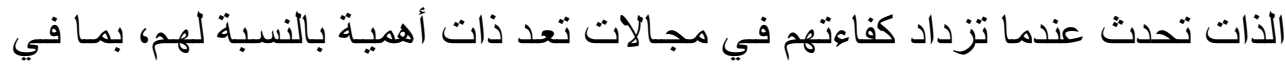

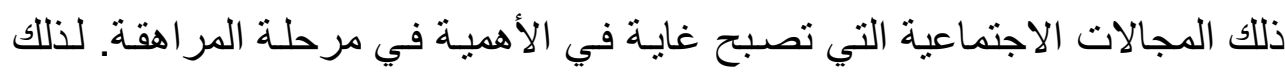

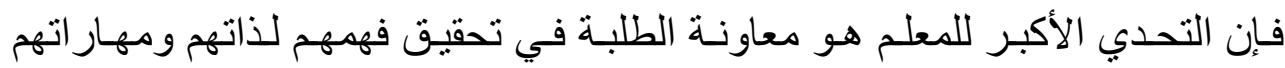
وتقدير ذات القيمة (وولفوللك، 2015). ويوردماكاي، وفانينج (2016)وليندنفيل (2005 ب) قائمة بالسمات العامة لمن لايهم تقدير مرتفع للاتات، ومنها:أنهم جديرون بالحياة، وو اثقون بأنفسهم، ويقبلون أنفسهر

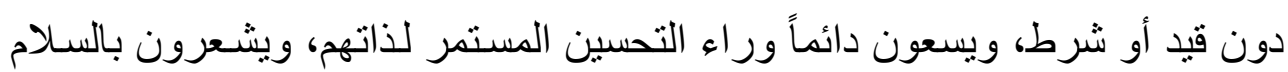

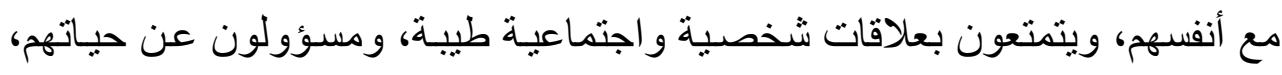


ويتعـاملون مـع الإحباطـات بشـكل جيـد، ولـديهم قدرة على الحسـم، و اجتمـاعيون و انبسـاطيون، و علـى اسـتعداد لاتخـاذ مغـامر ات محسـوبة، ومحبـون ومحبوبـون، وموجهون ذاتياً، ومتعاونون. وقائمة السمات العامة لمن لديهم تقدير منخفض للذات، و ونها:أنهم لا يحبون المغـامرة، ويخافون من المنافسة و التحديات، وسـاخرون، و لا يتسمون بالحسم، ويفتقرون إلى روح المبادرة، ومنشائمون، وخجولون، ومترددون، ومتـوترون، ويفتقرون إلى قبول الذات، ويشـرون بـأنهم غير جديرين بالمحبـة، ويلومون الآخرين على جو انب قصور هم الشخصية، وتدني طموحاتهم، وشعور هم بالعجز وقلة الحيلة. النظريات المفسرة لتقدير الذات: ـ نظرية روزنبرغ(Rosenberg): تعرض محمد (2010) هذه النظرية استناداً إلى روزنبرغ(Rosenberg, 1989) ، حيث تدور أعماله حول محاولته در اسـة تطور وارتقاء سـلوك تقييم الفرد لذاتهه وسـوكه، مـن زاويـة المعـايير السـائدة في الوسط الاجتماعي المحيط بالفرد. وقد اهتم بصفة خاصـة بدر اسـة تقييم المر اهقين لذواتهم، ووسع دائرة اهتمامه بعد ذلك حيث شملت ديناميات تطور صورة الذات الإيجابية في مرحلة المر اهقة، واهتم بالدور الذي تقوم بـه الأسرة في تقدير الفرد لذاته، و العمل لــل على توضيح العلاقة بين تقدير الذات الذي يتكون في إطار الأسرة وأسـاليب السلوك الاجتماعي اللاحق للفرد فيما بعد، كمـا اهتم بشرح وتفسير الفروق التي توجد بين الجماعات في تقدير الذات مثل الفروق بين الأعراق، والفروق في تقدير الذات عبر مر احل العمر. و اعتبر روزنبرغ (Rosenberg) أن تقدير الذات مفهوم يعكس اتجاه الفرد نحو نفسه. وقام روزنبرغ(Rosenberg) مقياساً لتقدير الذات؛ اعتبر من أفضل المقاييس في هذا الموضوع، وقد استخدام طريقة التحليل العاملي، لذللك فهو يستخدم في عدد كبير من الدر اسات (Heatherton, \&Wyland, 2003). (و الذي سوف يستخدم في هذه 
- نظرية كوبر سميث (Smith): يذهب سميث (Smith, 1981) الوارد في محمد

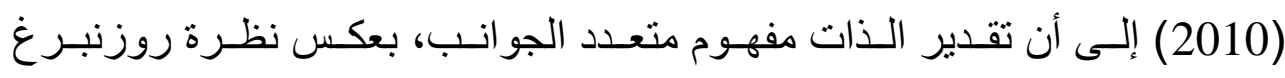
لهذا المفهوم المتمثنل بأحاديـة البعد. ويميز سميث (Rosenberg)

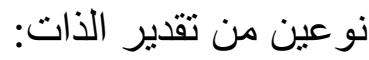

1. تقدير الذات الحقيقي: ويوجد عند الأفراد الذين يشعرون بالفعل أنهم ذوو قيمة. 2. تقدير الذات الدفاعي: ويوجد عند الأفراد الذين يشعرون أنهم غير ذوي قيمة، ولكنهم لا يستطيعون الاعتر اف بمثل هذا الثعور ، و التعامل على أساسـه مـع أنفسهم ومع الآخرين. وقد ركز سميث (Smith) على خصـائص العملية التي تصبح من خلالهـا مختلف جو انب الظـاهرة الاجتماعيـة ذات علاقـة بعمليـة تقيميم الذات. وقد افترض في سبيل ذلك أربع مجموعات من المتغير ات تعمل كمحدات لتقدير الذات و هي: النجاحات، و القيم، و الطموحات، و الدفاعات. - نظرية ماسلو (Maslow theory): وضع ماسلو (Maslow) في هرم الحاجات النفسية للفرد الحاجة إلى تقدير الذات، متضمناً أمرين:الأول؛ الحاجـة إلى التقدير الذاتي: ويتضمن الثـعور بالكفاءة، والإنجاز العالي، والاستقلالية، والعمل الكفء. والثاني؛ تقدير الآخرين: ويتضـن تقبل الآخرين والاعتراف بهم ( Schunk,

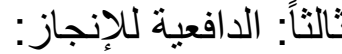
يرجع عبد الخـالق الوارد في خليفة (2000) استخدام مصطلح الدافع للإنجاز (Achievement motivation) أدلر (Adler)، الذي أثـار إلى أن الحاجـة للإنجاز هي دافع تعويضـي مستمد من فن خبرات الطفولة، و العالم ليفين (Levin) الذي عرض هذا المصطلح في ضوء تناوله لمفهوم الطموح(Aspiration)، وذلك قبل استخدام موراي (Murray) لمصطلح 
ويختلف المتعلمون عادة من حيث قوة رغباتهم في وضع أهداف مستقبلية لأنفسهم، وفي مدى الجهود التي يكرسونها لتحقيق هذه الأهداف، ويُنسب هذا الاختلاف إلى تباينهم في مستويات الدافعية التي يمتلكونها. ويرجع الفضلللعالم مور اي(Murray) في إدخال مفهوم الدافع للإنجاز إلى التراث السيكولوجيوتحديده، و إرساء الأسس التي يمكن أن تستخدم في قياسـ، هذا وقد حدد عدداً من الحاجـات دعاهـا حاجـات عالميـة (Universal needs) عرقهم أو عمر هم. وكانت الحاجة للإنجاز (Need to achieve) من بين الحاجات العالميـة التي أقر موراي(Murray) بوجودهـا و عرفها بمجموعـة القوى والجهود التي يبذلها الفرد مـن أجل التغلب على العقبـات وإنجـاز المهام الصـعبة بالسـرعة الممكنة، وبأكبر قدر من الاستقلال(نشواتي، 2002) (موراي، 1988). ويشير محمد، ومرسي (1986) إلى الدافعية للإنجاز على أنها مفهوم فرضي يدل على حالـة نفسـية داخليـة، تـدفع الثـخص إلىى النثـاط و العمـل و الإنجـاز ، لتـدريب المهار ات وتنمية القدر ات، و اكتسـاب الخبر ات، وتحقيق النجـاح و التفوق، و الثـور بالكفاءة والحصول على تقدير الآخرين وتقبلهم، ويختلف التعبير عن الدافع للإنجاز عند الفرد بحسب مر احل تطوره النفسي؛ ففي الطفولـة يعبر الطفل عن هذه الحاجـة في اللعب، ومساعدة أمه في الأعمال المنزلية، وتنفيذ ما يطلب منه، وفي رغبته في الاعتمـاد على نفسـه في اللبس و المشـي وتنـاول الطعـام. وفي الطفولـة المتـأخرة و المر اهقة يعبر الفرد عن حاجته للإنجاز بالر غبـة في التحصبل و إنجاز الواجبات المدرسية، وتنفيذ مشاريع التربية الفنية والعملية، والإقبال على الأنشطة التي تتمي المهار ات و الخبر ات والقدرات، و الرغبـة في المنافسـة و التفوق، وتحمل المسؤولية، و اتخاذ القرار ات. في حين يعبر الفرد عن هذه الحاجة في الرشد بالنجـاح في العمل، والتفوق في أدائه والابداع فيه، وفي تحمل المسؤوليات، وإنجاز الواجبات والأنشطة 
و أما الرفوع (2015) فيشير إلى أن دافع الإنجاز يعد مكوناً جو هرياً في سعي الفرد

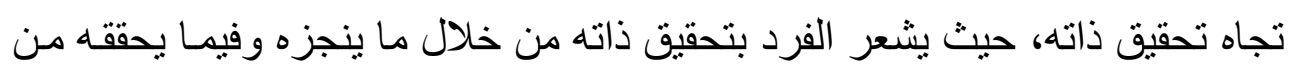

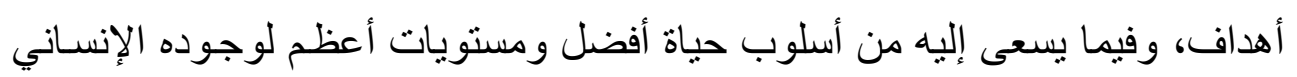
الواعي. النظريات الدفرة لدافعية الإنجاز: يشير لي بيتري، وجوفري (2016) إلى أن مور اي (Murray) يعتقد أنه يمكن تقسيم الأفر اد طبقاً لمدة قوة الحاجة لديهم في جو انب متعددة، واحدة منها هي حاجتهم

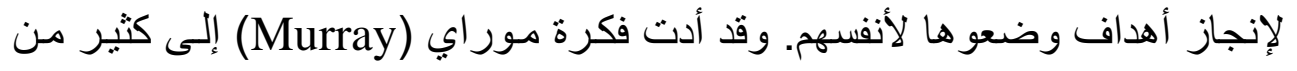
البحوث عن دافعية الإنجاز ؛ والكثير منها قام على أساس من نظرية التوقع- القيمة. وكمـا يشبر خليفة (2000) إلى أن مور اي(Murray) قدم مفهوم الحاجـة للإنجاز

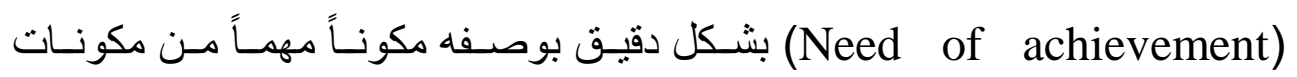

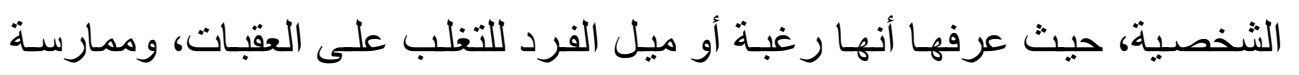
القوى و الكفاح أو المجاهدة لأداء المهام الصعبة بشكل جيد وبسر عة وعة كلما أمكن ذلك.

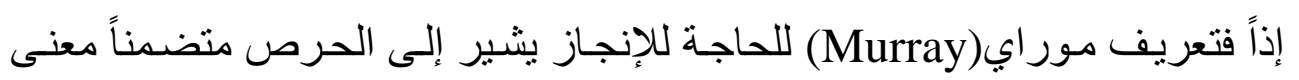

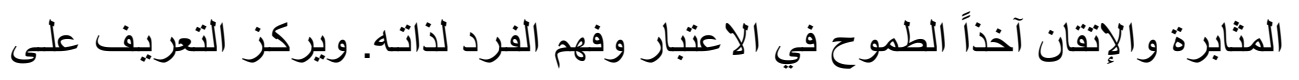

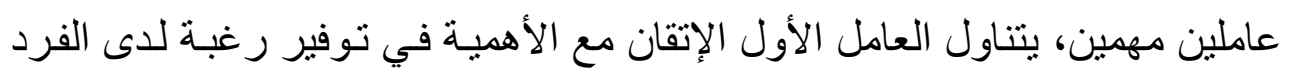

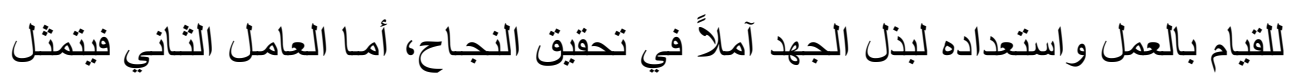

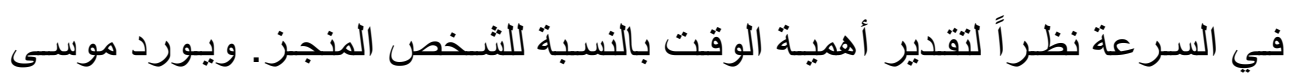

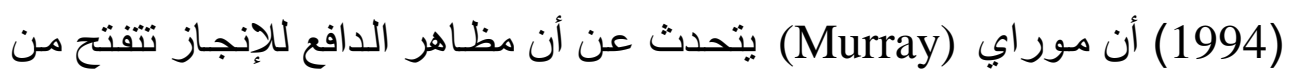
خلال سعي الفرد إلى القبام بالأعمال الصـعبة، وبر اعته في تنـاول وتنظيم الأفكار

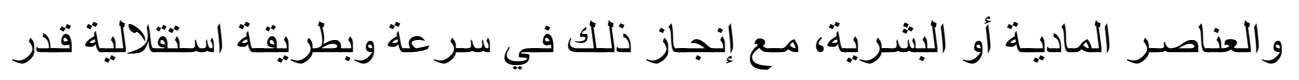

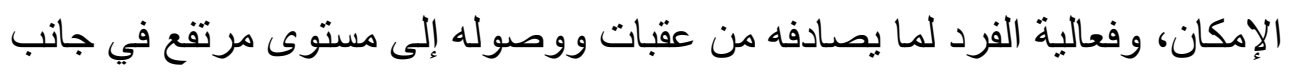

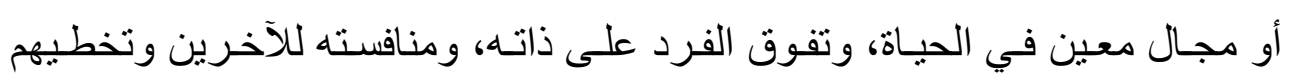


و التفوق عليهم، وازدياد تقدير الفرد لذاتـه من خـلال الممارسـة الناجمة لمـا لديـه من قدر ات و إمكانات.

غير أن هذا المفهوم قد أخذ في الانتشـار منذ خمسينيات القرن الماضـي من خلال

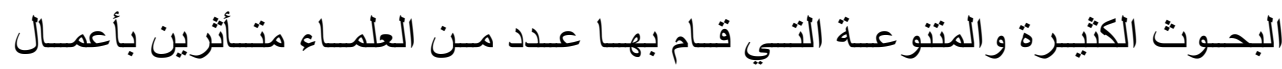
موراي(Murray)؛ أمثال ماكليلاند (McClelland) و أتكنسون(Atkinson)،حيث

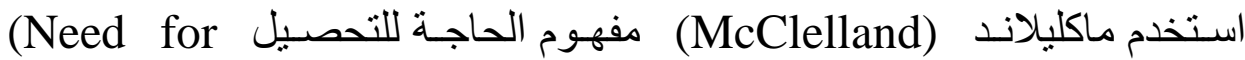
achievement) تنافسية طبقاً لمعيـار تفوق معين (موسـى، 1994)، بـل وربطهـا بالثقافـة وعمليـة التنشئة الاجتماعية (Socialization) للفرد (عسكر، و القطار ، 2005)، ولكن لـ يختلف مفهوم الدافع إلىى الإنجـاز عند ماكليلانــ (McClelland) عمـا يقصـده موراي(Murray) بمفهوم الحاجـة إلى الإنجاز ، بـل إن المصـادر الأصلية المتعددة لهذا المفهوم تستخدم مصطلح مور اي(Murray) ذاته للالالـة على مـا تقصده هذه المصادر بمفهوم الدافع إلى الإنجاز (عبد الله، 2003)، ولقد أثروا في هذا المجال بدر اسـاتهم العديدة والتي كللتهـا فيمـا بعد مئـات الدر اسـات (لـي بيتري، وجـوفرن، 2016) (البيلي، و العمادي، و الصمادي، 2016).

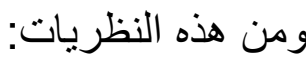
- نظرية ماكليلاند(McClelland theory): وكما يشير الرفوع (2015)أن تصور ماكليلاند (McClelland) لدافعيـة الإنجاز جـاء في ضـوء وجود جوانب عاطفيـة تـرتبط بالحاجـة إلـى الإنجـاز ، مثـل الثــهرة، والطهـوح، والحاجـة إلـى الحريــة، و الاستقلال، و السيطرة، و السعادة أو المتعة بالحاجة إلى الإنجاز. ويوردموراي (1988) صفات الأفراد الذين يتمتعون بدافعية إنجاز قوية وعالية بأن لـديهم: اسـتعداد سـريع للتعلم، وثقـة بـالنفس عاليـة، وتفضـيل المسؤولية الفرديـة، وتفضيل المعرفة المفصلة بنتائج أعمالهم، ومقاومـة الضـط الاجتمـاعي الخـارجي، وتبني مستو يات مرتفعة من الطموح، والميل إلى إدر الك العـالم من زوايـا مختلفة، 
وتثير هذه النظرية إلى أنه في ظل ظروف ملائمة سوف يقوم الأفراد بعمل المهام

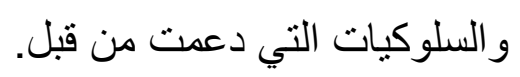

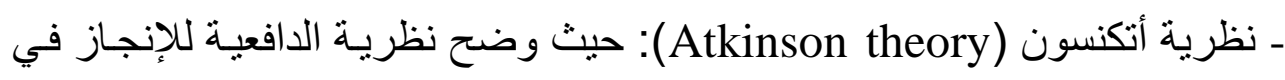
إطـار نظريـة التوقع - القيهة (Expectancy - value theory) في الإنجاز على ونى أساس أن النجاح يتبعه الثعور بالفخر والزهو ، والفثل يتبعه الثعور بالخجل وخيبة

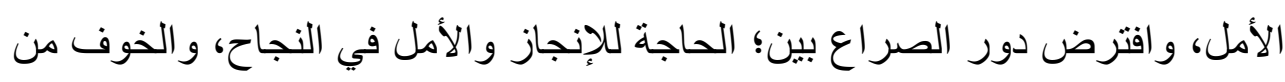
الفثل، كما افترض أن الميل للنجاح هو ميل دافعي متعلم ثابت نسبياً، وقوة هذا الميل

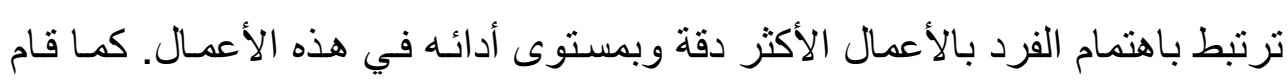

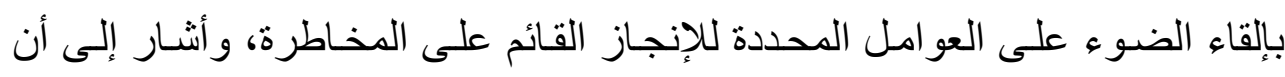

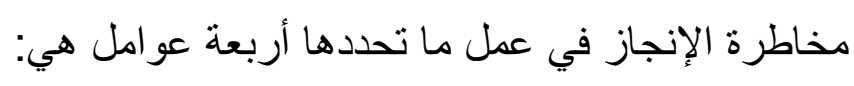
1 - فيما يتعلق بصفات الفرد (المحددات الفردية أو الثخصية لدافعية الإنجاز): ويعبر

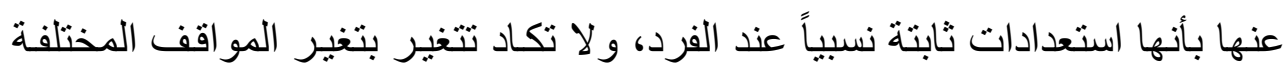

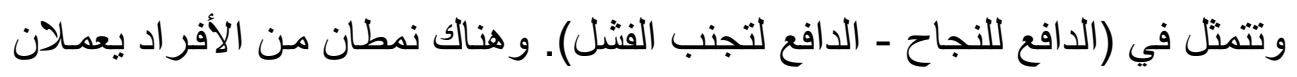
بطريقة مختلفة في مجال التوجه نحو الإنجاز هما:

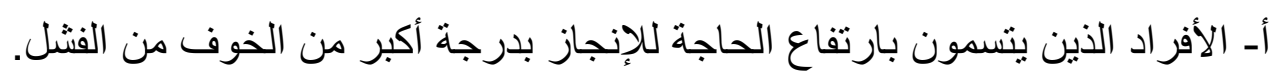
بـ الأفر اد الذين يتسمون بارتفاع الخوف من الفنشل بالمقارنة بالحاجة للإنجاز .

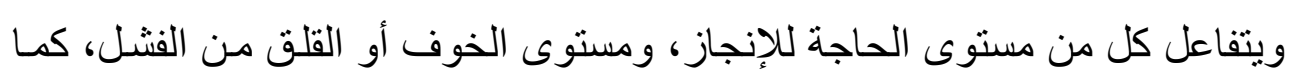

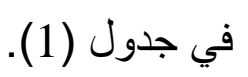


جدول ( ) تفاعل كل من مستوى الحاجة للإنجاز ، ومستوى الخوف أو القلق من الفشنل

\begin{tabular}{|c|c|c|c|}
\hline مستوى القلق من & مستوى الحاجة للإنجاز & النمط & \\
\hline منخفض & مرتفع & الدافع للإنجاز والنجاح أكبر من الدافع & 1 \\
\hline مرتفع & منخفض & الدافع لتحاثي الفشل أكبر من الدافع للإنجاز & r \\
\hline
\end{tabular}

ويعبر عنها باحتمالات النجاح أو الفثل، وجاذبية الباعث الخـارجي الموجب للنجاح أو قيمة الباعث السـالب المترتب على الفشـل. وهناك نمطسان من خصـائص المهــة is

أـ احتماليـة النجـاح (Ps) (Probability of success) ونتـير إلى الصـعوبة المدركة للمهمة، وهي أحد محددات المخاطرة. ب- الباعث للنجاح في المهمة (Is) (Task Incentive for success)، ويقصد به الاهتمام الداخلي/ الذاتي لأي مهمة بالنسبة للشخص (الرفوع، 2015) (خليفة، و عبد الله، 2011). و على ذلك، فإن تغير ناتج الإنجاز عند الأفر اد المختلفين يرجع إلى الثق الأول من المعادلة، و عند الفرد الواحد من موقف لآخر يرجع إلى الثـق الثاني، حيث تصبح دو افع النجاح ودو افع تجنب الفشل هي المحددات الأساسية لدافعيـة الإنجاز (الزيـات، . (2004 إن نظرية التوقع - القيمة توضح العلاقات الرياضية التي تتنبأ بميل الأفر اد للإقدام على النجـاح (دو افع الإقدام) أو تجنب الفثـل (دوافع الإحجـام) من خـلال الأنشطة المرتبطة بالإنجاز ، و هذا التتبؤ يحدده التفاعل بين مكونـات متوازيـة هي حالـة الميل للإقدام على النجاح (Tendency to success) على النحو الآتي: 
1. الدافعية للنجاح (Motive to success). r. احتمالات أو توقع النجاح (Probability of success). r. قيمة الباعث للنجاح (قيمة النجاح)(The incentive value of success). كما أن الميل لتجنب الفشل (To tendency to avoid failure) محصلة عوامل

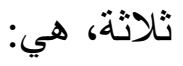
1 الخوف من الفثل أو الميل لتجنب الفنش(Motive to avoid failure). r. احتمالات الفنل (Probability of failure). r. قيمة الباعث لتجنب الفشل (Incentive value to avoid failure) (الزيات، .(2004 ويلخص لي بيتري، وجوفري (2016) نظريـة أتكنسون (Atkinson) الذي أكد

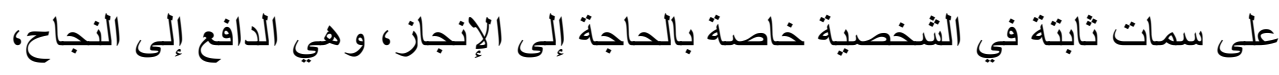

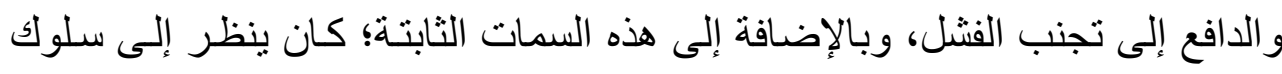

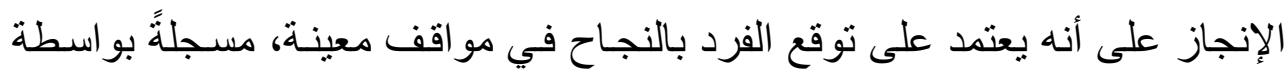

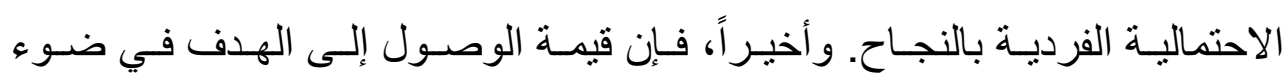

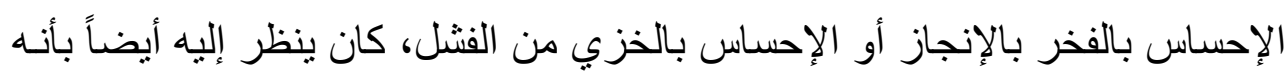
ذو أهمية في تقرير سلوك الإنجاز. و ويؤكد أنكنسون (Atkinson) على أن الأعمال

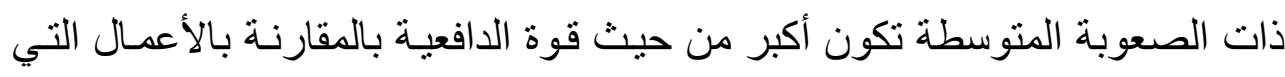

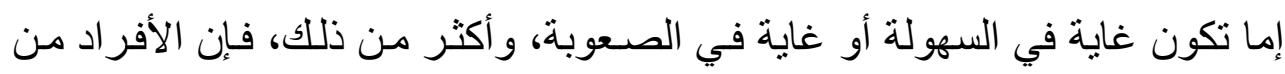
ذوي المستوى المرتفع لدافع النجاح، يجب أن يتم دفعهم للاشتر الك في هذه الهن الأعمال

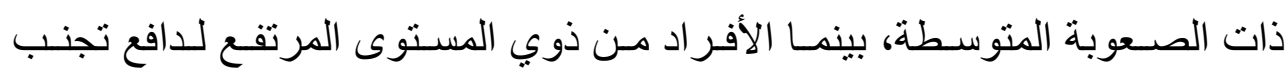
الفثل، يجب أن يتجنبو ها. ويميل الأفر اد الذين لديهم دافع أقوى للنجاح إلى البحث وتنـاول المهـات الصعبة

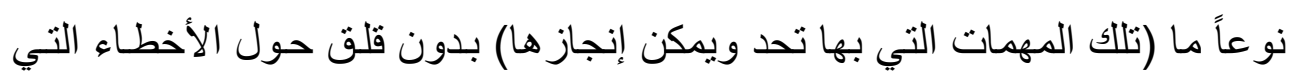

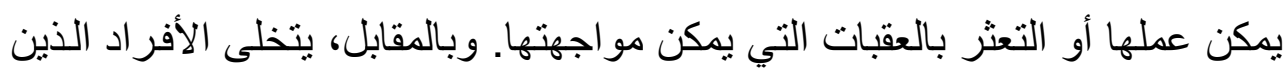


لديهم دافع أقوى لتجنب الفشل بالعادة عن المخاطر لصـالح شيء مؤكد. وبإعطائهم

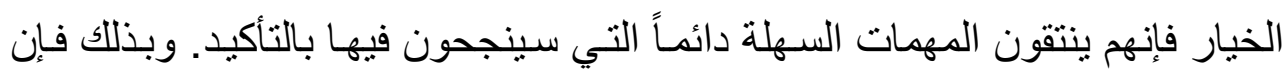
الأفر اد الذين لديهم دافع عال لتجنب الفشل يختارون دائماً مهمات صعبة جداً (هؤلاء الذين لا يستطيعون النجاح) و عندما ينخرطون في تلاك المهمات فإنهم يبنون تفسيراً داخلياً (وبعد كل ذلك فالمهمـة مستحيلة)، ويستطيعون بسـهولة أن يجدو ا تفسيراً

$$
\text { منطقياً لفشلهم (أورمورد، 2016). }
$$

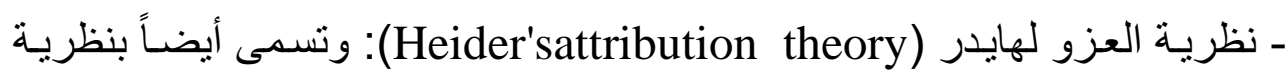

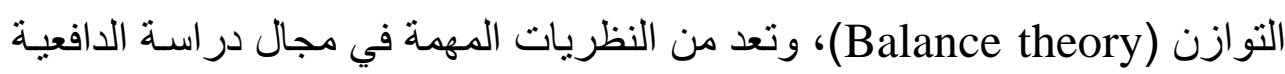

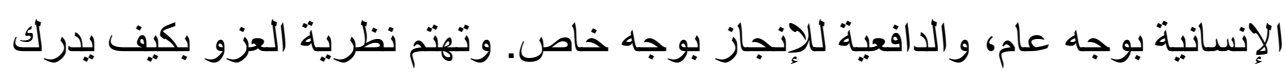
الثخص أسباب سلوكه، وسلوك الآخرين. وذللك لأن الأفر اد لا يعزون السبيبة للفاعل فقط، ولكن أيضاً للبيئة. ويعد هايدر (Actor)

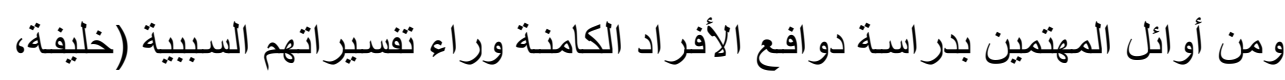

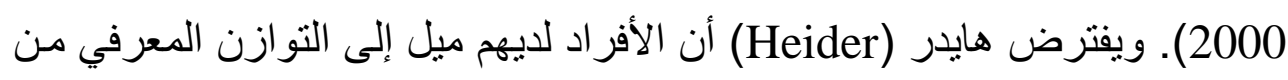

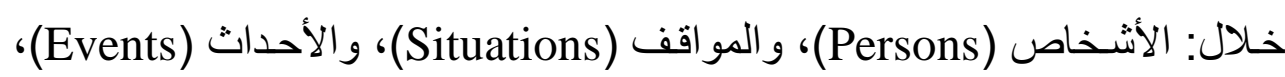

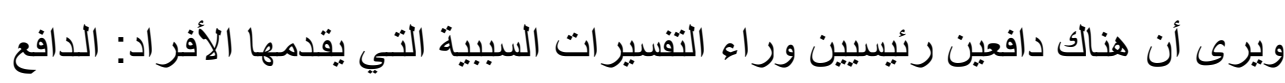

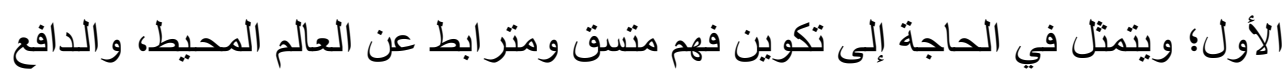

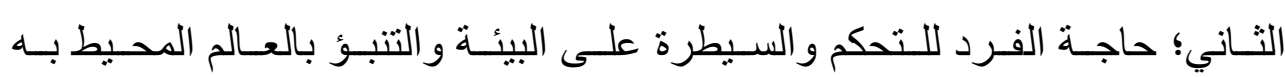

.(Schunk, 2012)

وتندرج نظرية العزو ضمن النظريات المعرفية المفسرة للافعية، و التي تنطلق من

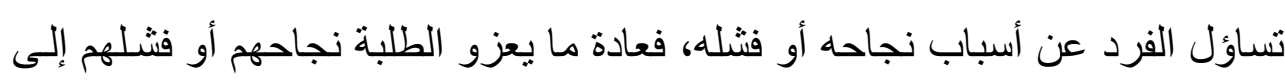

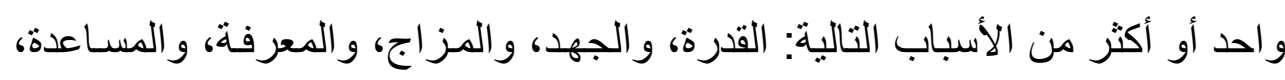

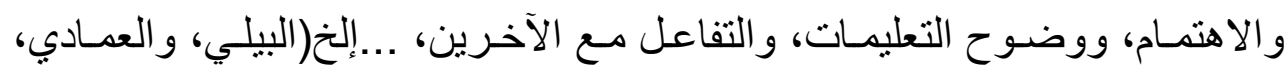
و الصمادي، 2016). 
ويشير خليفة، وعبد الله (2011) إلى أن هناك دافعين رئيسيين وراء التفسيرات

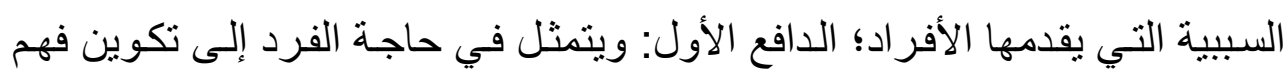

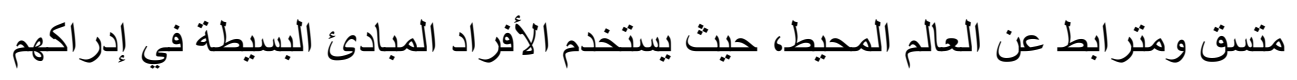

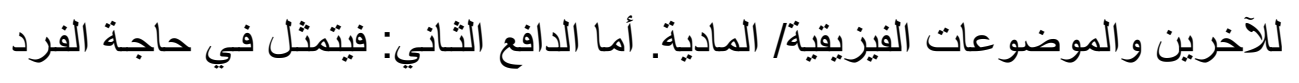

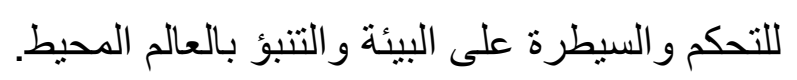

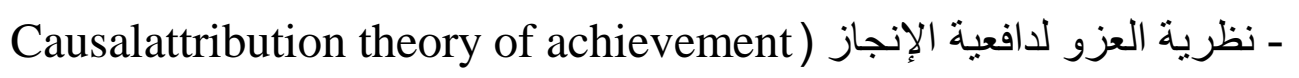
(motivation): يعتبر واينر (Weiner) من أبرز علماء النفس التربوي المسؤولين

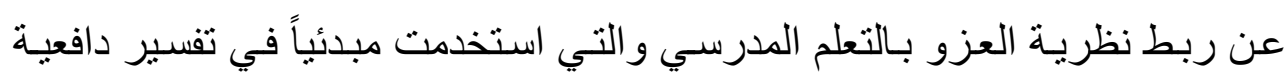
الإنجاز. ولكن؛ بعد ذلك تم تطبيق النظرية على مدى و اسع من الموضو عاتلفئ (البيلي،

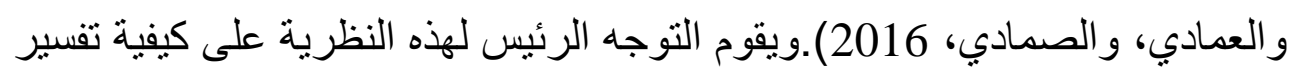

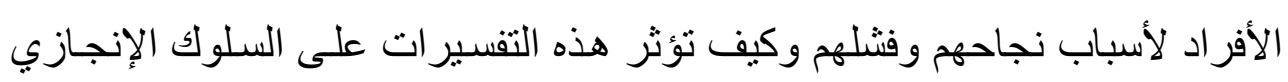

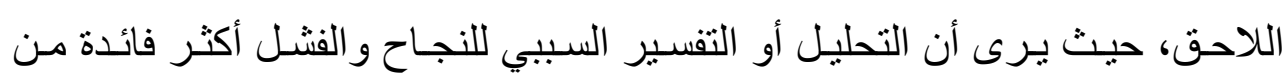

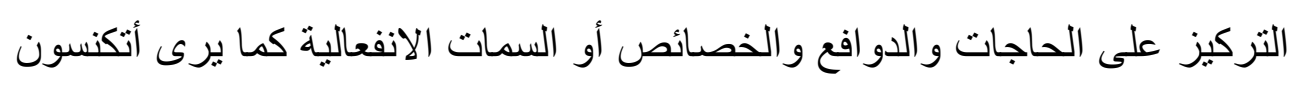
(Atkinson)

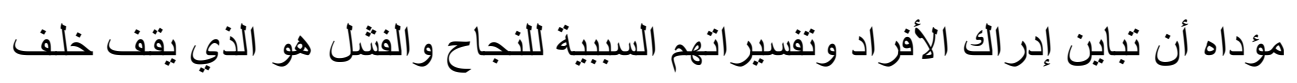

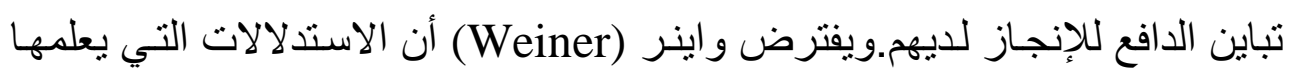

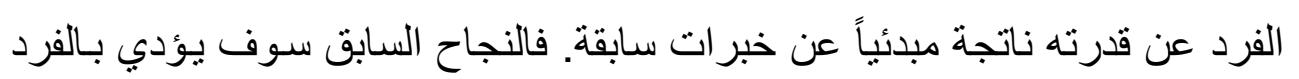

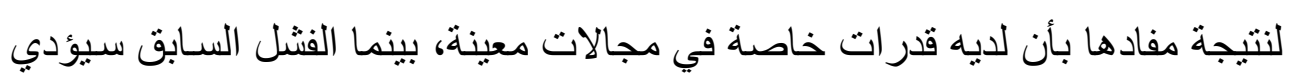

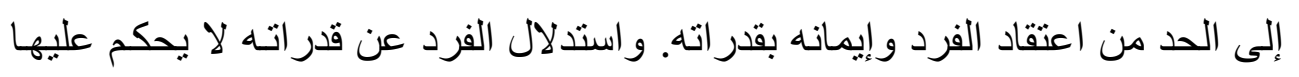

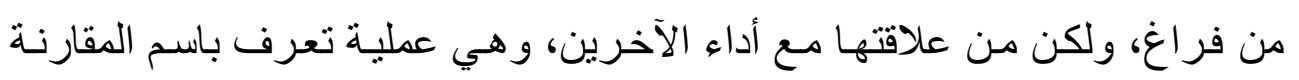

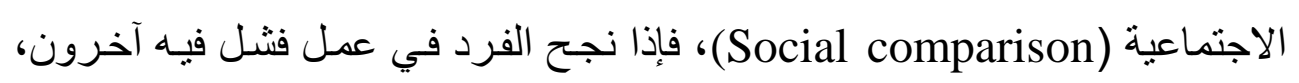

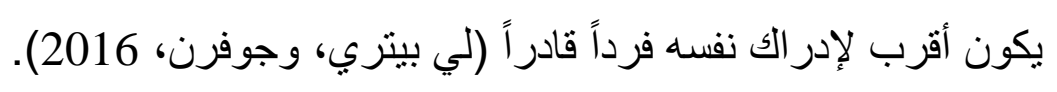

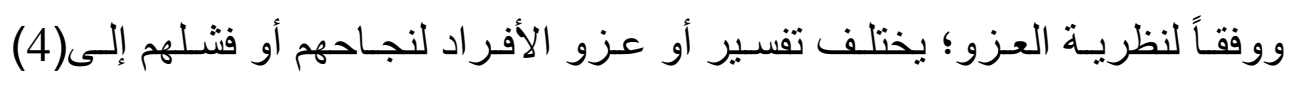

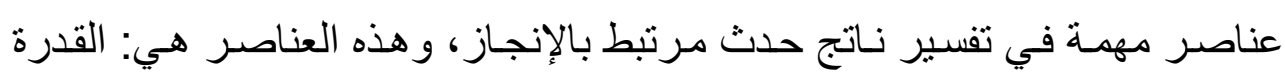




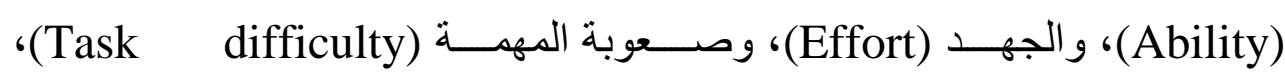

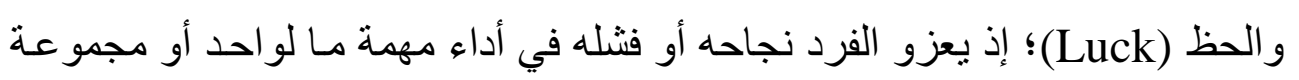

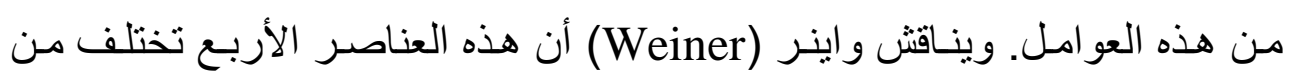

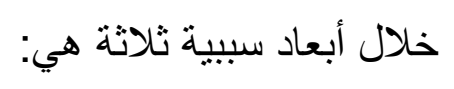
- موقع الضبط(Locus): حيث يثير موقع الضبط إلى الاعتقاد بمـا إذا كان السبب هيب

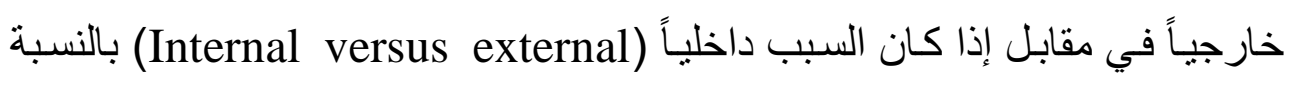

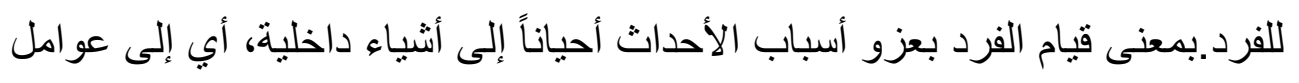

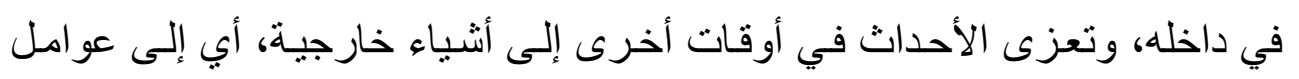

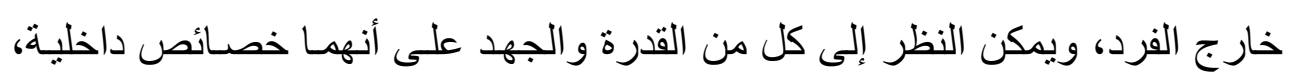

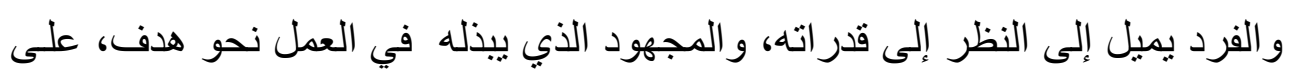

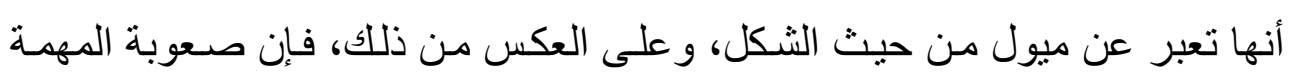

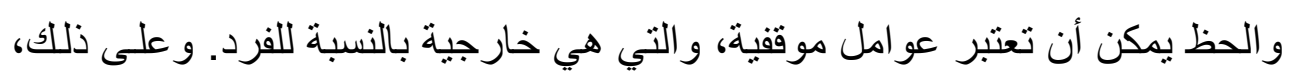

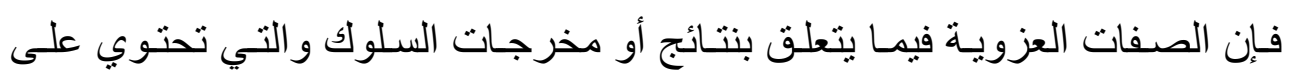

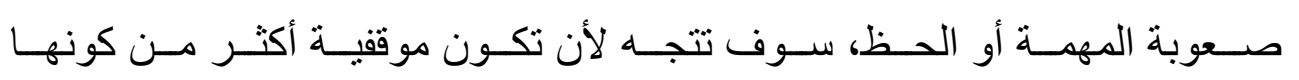

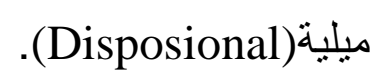

- الثبات/ الاستقرار(Stability): إما أن يكون هناك استقرار مقابل عدم الاستقرار حيث يفكر الفرد بأن الأحداث هي نتيجة العوامل (Stable versus unstable) المستقرة (أنثياء من المحتمل) أنها لا تتغير كثير اً في المستقبل القريب. ولكن يعتقد

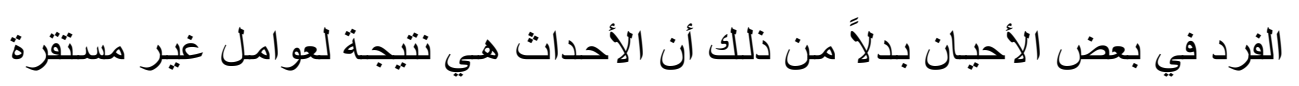

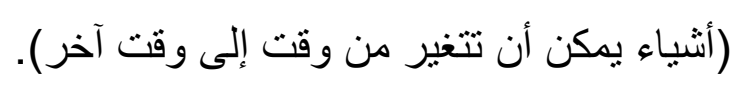

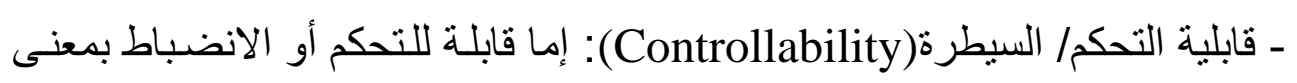
الأشياء التي يمكن ضبطها مقابل الأشياء التي لا يمكن ضبطها Controllable) (versus uncontrollable) 
يمكن ضبطها، وفي حالات أخرى يعزو الفرد الأحداث إلى عوامل لا يمكن السيطرة

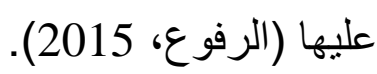
ويعتقد واينر (Weiner, 1992) الوارد في البيلي، و العمادي، و الصمادي (2016)

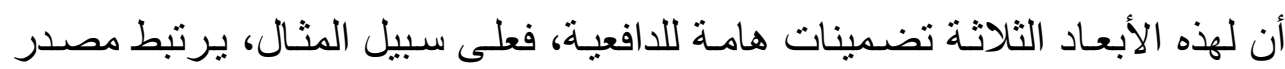

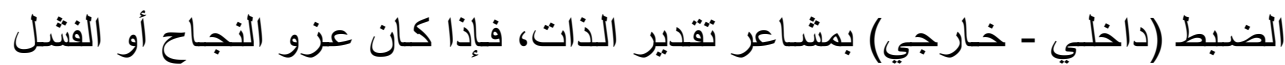
يعود إلى عوامل داخلية، فالنجاح يؤدي إلى الثُعور بالزهو و الافتخار مما يؤدي إلى الى زيادة الدافعية، بينما يؤدي الفثل إلى انخفاض في تقدير الذات. وتؤكد أورمورد (2016) أن العزو له تأثثر ذو أهمية على أداء المتعلمين و إنجاز هم في الغرفـة الصـفية. ويـؤثر العـزو خصوصـاً في اسـتجابات المتعلمـين الانفعاليـة

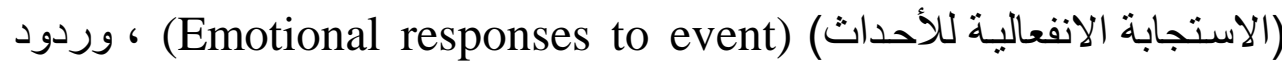
(Reactions to reinforcement and الفعـل نحـو التعزيـز و العقـاب ) (Self-efficacy and و و الكفــاءة الذاتيــة والتوقعــات punishment) expectancies) و والجهد و المثابرة (Effort and persistence)، واستر اتيجيات التعلم (Learning strategies)، وخيار ات المستقبل و الأهداف Future choice) (and goals)

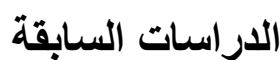
تم تنظيم الدراسات السابقة تبعاً لصلتها بموضوع الدراسة وتسلسلها الزمني التنازلي

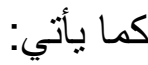
الاراسات المتعلقة بالتعلم المستند إلى الدماغ باتي

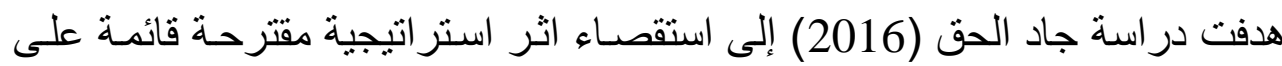

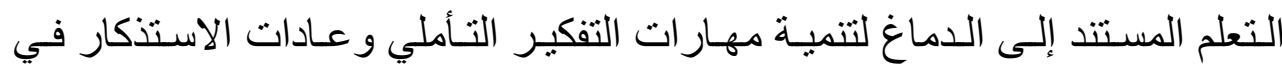

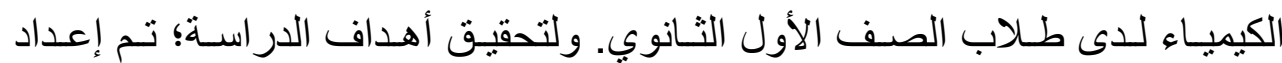
وتطبيق اختبار مهارات التفكير التأملي، ومقياس عادات الاستذكار في الكيمياء، 
بالإضـافة إلى الاسـتر اتيجية المقترحـة القائمـة على التعلم المسـتند إلى الـماغ في وحدتين من مادة الكيمياء، ودليل المعلم، على عينة الدر اسة المكونة من (119) طالباً من طلاب الصف الأول الثانويفيإحدى مدارس محافظة الثرقيةبمصر خلال الفصل الدر اسي الثاني (2015/2014). وقد تم توزيعهم على مجمو عتي الدراسة؛ التجريبية (59 طالباً) و الضـابطة (60 طالباً). وقد أظهرت نتائج الدر اسـة وجود فروق ذات دلالـة إحصـائية في مهار ات التفكير التأملي ككل وفي مهار اته الفرعيـة، وعـادات الاستذكار ككل، وفي عاداته الفرعية كلاً على حدة، ولصالح المجموعة التجريبية. هدفت در اسة الخو الدة، وقطاوي (2015) إلى استقصاء أثر برنامج تعليمي قائم على التعلم المستند إلى الدماغ في تحسين مهار ات التفكير الابداعي والتحصيل في مبحث التربيـة الاجتماعيـة و الوطنيـة. ولتحقيـق أهداف الدر اسـة؛ تـم إعداد وتطبيـق اختبـار مهـار ات التفكيـر الابـداعي، والاختبـار التحصـيلي في مبحـث التربيـة الاجتماعيـة و الوطنية، بالإضـافة إلى البرنامج التعليمي المستند إلى الدماغ، على عينـة الدر اسـة المكونة من (50) طالباً من طلاب الصف الثالث الأساسي في مدينة المفرق بالأردن

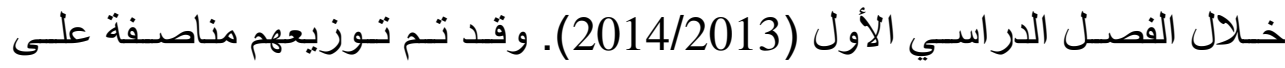
مجمو عتي الدراسة؛ التجريبية والضـابطة. وقد أظهرت نتائج الدراسـة وجود فروق ذات دلالـة إحصـائية في تحسـين مهـار ات التفكيـر الابـداعي: الطلاقـة، و المرونـة، و الأصالة، والتحصيل في مبحث التربية الاجتماعية والوطنية، ولصـالح المجموعـة التجريبية.

و هدفت در اسة السو اط (2015) إلى التعرف على فعالية برنـامج تدريبي قائم على نظرية التعلم المستند إلى الدماغ في تنمية الكفاءة الذاتيـة الأكاديميـة المدركة وبعض عـادات العقل. ولتحقيـق أهداف الدر اسـة؛ تـم إعداد وتطبيـق مقيـاس الكفـاءة الذاتيـة الأكاديمية المدركة، ومقباس عـادات العقل، بالإضـافة إلى البرنـامج التدريبي القائم على نظرية التعلم المستند إلى الدماغ، على عينـة الدر اسـة المكونـة من (60) طالباً من طلاب جامعة الطائف بالسعودية خلال العام الدر اسي الجـامعي (2015/2014). 
وقد تم توزيعهم مناصفة على مجمو عتي الدراسة؛ التجريبية والضابطة. وقد أظهرت نتـائج الدر اســة وجـود فروق ذات دلالـة إحصـائية بـين منوسطي درجـات طـلاب مجموعتي الدراسة على مقياس الكفاءة الذاتية الأكاديمية الدركة، ومقياس عادات العقل، ولصالح المجموعة التجريبية. وهدفت در اسـة الطيطي، ورواشـدة (2013) إلى الكثـف عن أثر برنـامج تعليمي

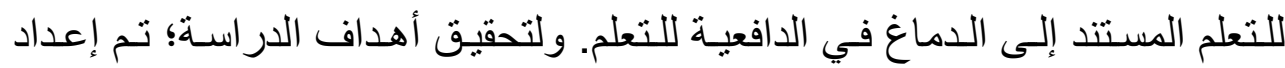
وتطبيق مقياس دافعية التعلم، والبرنامج التعليمي المستند إلى الدماغ، على عينـة

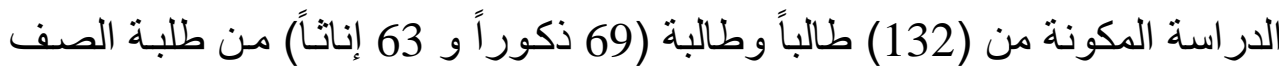

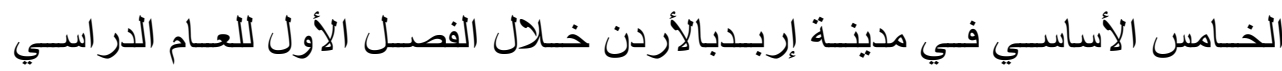
(2014/2013). وقد تم توزيعهم على (4) مجمو عات منسـاوية؛ اثنتين تجريبيتين، و اثنتين ضابطتين. وقد أظهرت نتائج الدراسـة وجود أثر للبرنامج التعليهي المستند إلى الدماغ في تحسين الدافعية في العلوم لدى طلبة المجمو عتين التجريبيتين، ووجود

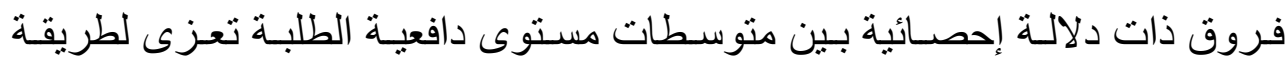
التدريس، ولصالح المجموعتين التجريبيتين، ولم تظهر النتائج أية فروق ذات دلالة إحصائية تعزى لمتغير الجنس، أو للتفاعل الثنائي بين طريقة التدريس و الجنس.

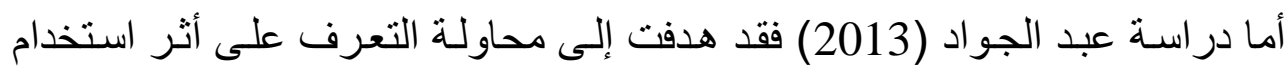
برنامج قائم على نظرية التعلم المستند إلى الدماغ في تنمية بعض مهار ات التفكير

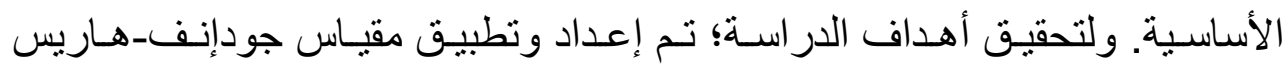
للاككاء، واختبار مهار ات التفكير الأساسية لطفل الروضة، وبرنامج قائم على مبادئ

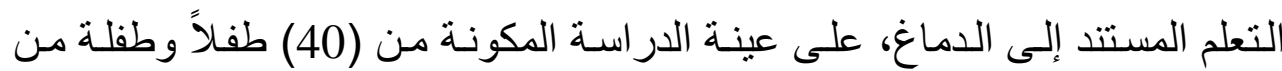
أطفال المستوى الثاني بالروضة في محافظة المنيا بمصر ـ وقد تم توزيعهم مناصفة كنة

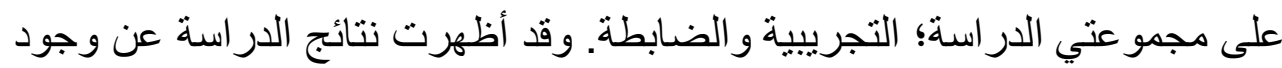
فروق ذات دلالة إحصـائية بين مجموعتي الدراسـة في مهار ات التفكير الأساسية، ولصالح المجمو عة التجريبية. 
وهدفت دراسة أحمد (2013) التعرف إلى أثر برنامج مقترح قائم على مدخل التعلم المستند إلى الدماغ في تصحيح التصـور ات البديلة وتتمية عمليات العلم و الدافعية الدية للإنجاز. ولتحقيق أهداف الدراسة؛ تم إعداد وتطبيق اختبار التصور رات البديلـة عن

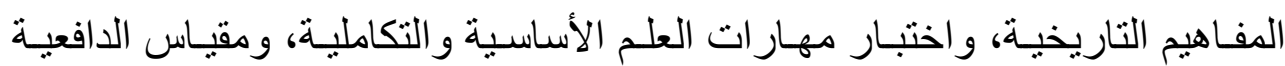
للإنجاز، بالإضافة إلى برنامج قائم على مدخل التعلم المستند إلى الدماغ في منهاج

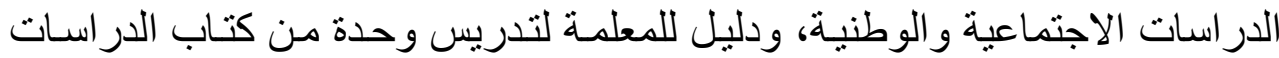
الاجتماعية والوطنية ضمن البرنامج المعد، على عينة الدراسـة المكونـة من (60) طالبة من طالبات الصف الأول المنوسط في منطقة الباحة بالسعودية خلال الفصل

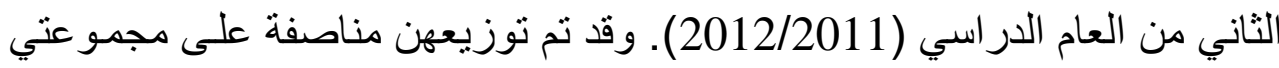

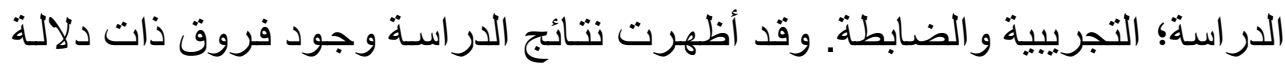
إحصـائية بـين منوســي درجـات طالبـات فـي مجمـوعتي الدر اســة في اختبـار

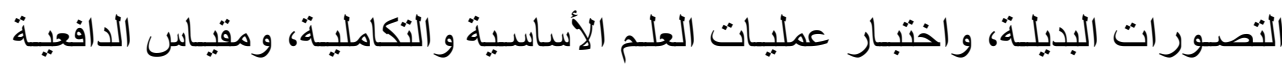
للإنجاز ، ولصالح المجمو عة التجريبية. و هدفت دراسـة بدر (2013) التعرف إلى فاعلية استر اتيجية مقترحسة قائمـة على ولى

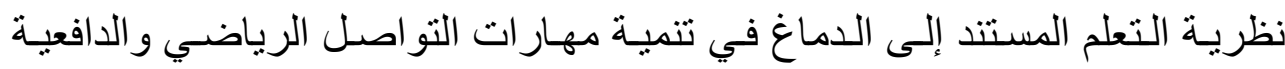
للإنجـاز الدراسي. ولتحقيـق أهداف الدراسـة؛ تـم إعداد وتطبيـق مقيـاس السيطرة

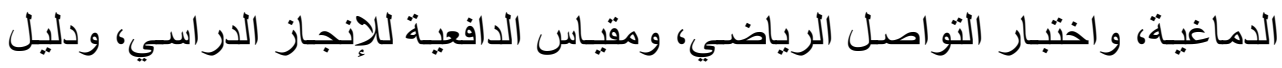

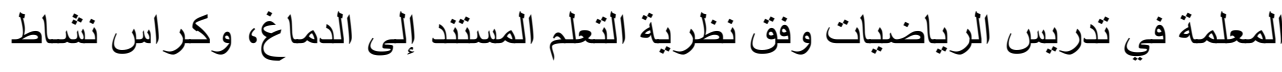

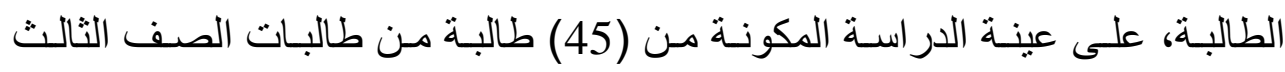

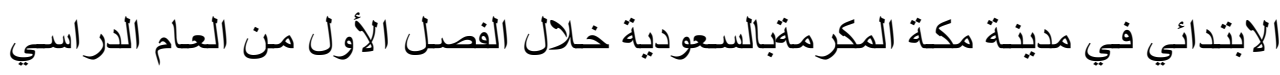

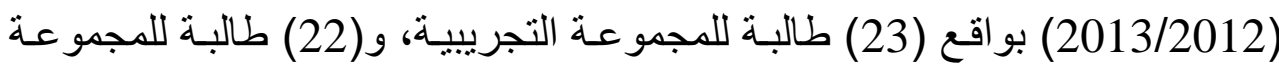
الضابطة. وقد أظهرت نتائج الدراسة وجود فروق ذات دلالة إحصائية في مهار ات التهات

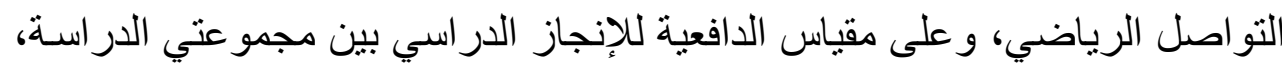
ولصالح المجموعة التجرييية. 
و هدفت در اسة الخليفة (2013) إلى تحديد فاعلية برنـامج تدريبي قائم على نظريـة

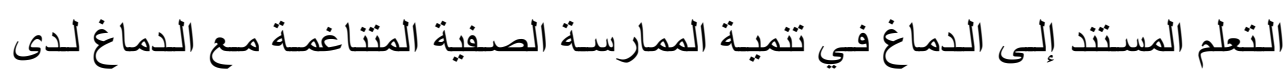
معلمات علوم الحلقة الثانية من التعليم الأساسـي (5-10) أثناء الخدمـة، وتحديد أثره على التظظيم الذاتي لتعلم طالبـاتهن مـن الصف التاسـع الأساسـي. ولتحقيق أهداف الدراسة؛ تم استخدام التصميم التجريبي ذي المجموعة الواحدة مـع التطبيق القبلي لأدو ات البحث،ثم تطبيق جلسات البرنامج و عددها (14) جلسـة، ثم التطبيق البعدي للأدوات. وتكونت عينة الدراسة من (20) معلمة من معلمات العلوم بمحافظة جنوب الباطنة بسلطنة عمان، و(510) طالبة من طالبات الصف التاسع من التعليم الأساسي

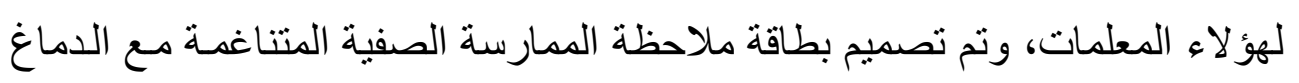
تكونت من (22) بنداً في (4) محساور، كما تم تصميم مقياس التنظيم الذاتي للتعلم ضم (5) أبعاد. وأثـارت نتائج الدراسـة إلى وجود فروق ذات دلالة إحصـائية بين نتائج التطبيق القبلي و البعدي لبطاقة ملاحظة الممارسة الصفية المتناغمة مـع الدماغ على معلمات العلوم اللاتي تم تدرييهن خلال البرنامج التدريبي، كمـا أشـارت النتائج إلى وجود فروق دالة إحصـائياً بين نتائج التطبيق القبلي و البعدي لمقياس التنظيم الـذاتي للتعلم على طالبـات الصـف التاسـع مـن التعلـيم الأساسـي لمعلمـات العلـوم المتدربات.

و هدفت در اسـة عزيز الرحمن وزملائه (Aziz-Ur-Rehman, et al, 2012) التعرف إلى فاعلية نظريـة التعلم المستند إلى الدماغ لدى طلاب المرحلة الثانويـة بالمناطق الحضرية في مادة الرياضيات. ولتحقيق أهداف الدر اسة؛ تم إعداد وتطبيق الاختبار التحصيلي لقيـاس فاعليـة طريقـة التدريس القائمـة على الدماغ، على عينـة

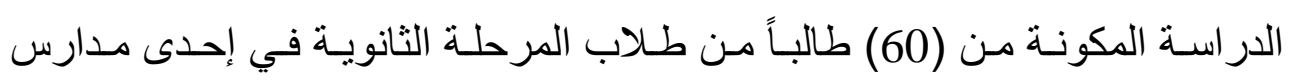
باكستان، بو اقع (30) طالباً للمجمو عة التجريبية، و(30) طالباً للمجمو عة الضـابطة. وقد أظهرت نتـائج الدر اسـة وجـود فـروق ذات دلالـة إحصـائية لأداء الطـلاب في الاختبار التحصيلي في مادة الرياضيات لصالح المجموعة التجرييية؛ تعزى لمبـادئ 
التعلم المستنـا إلى الدماغ في: المعالجة المتوازيـة، و البحث الفطري عن المعنى، و إدر الك الدماغ للكل و الجزء بشكل متواز، باستثناء التتميط.

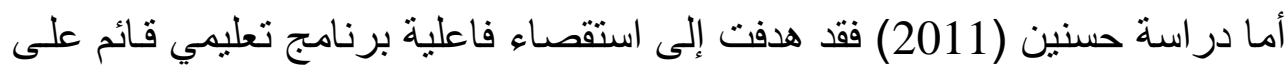
نظرية التعلم المستند إلى الدماغ في تحسين التحصيل، واكتسـاب المفاهيم العلميـة، وزيادة الدافعية للتعلم. ولتحقيق أهداف الدراسة؛ تم إعداد وتطبيق اختبار التحصيل،

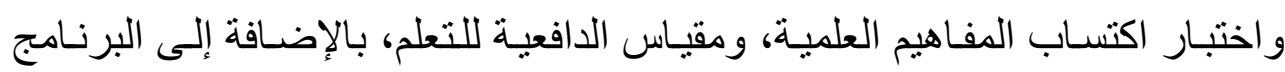

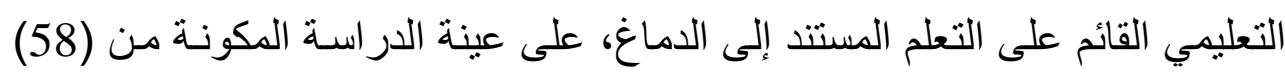

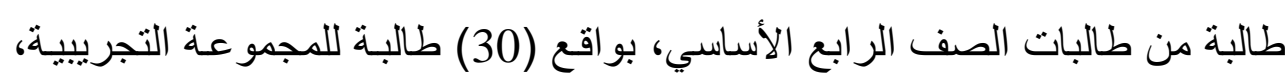

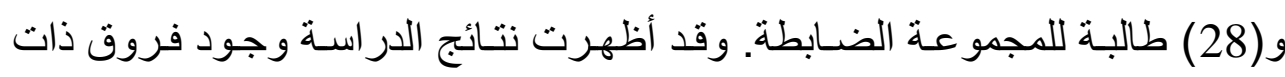

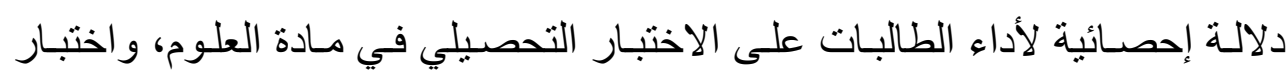
اكتساب الدفاهيم العلمية،ومقياس الدافعية للتعلم الكلي، ولصالح المجموعة التجريبية. وهدفت دراسـة دومـان (Duman, 2010) إلى معرفة أثر استخدام طريقة التعلم المستند إلى الدماغ على التحصيل الدر اسي للطلبة متنو عي أنماط التعلم. ولتحقيق

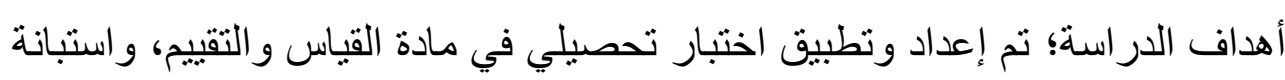

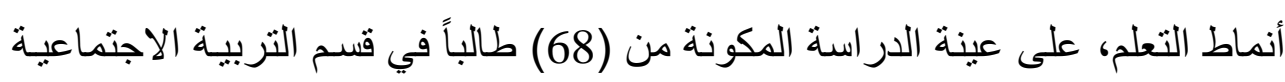

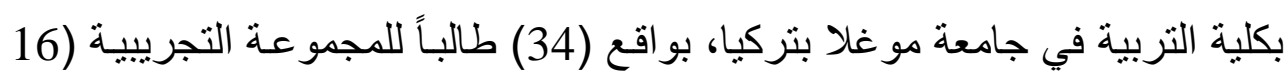

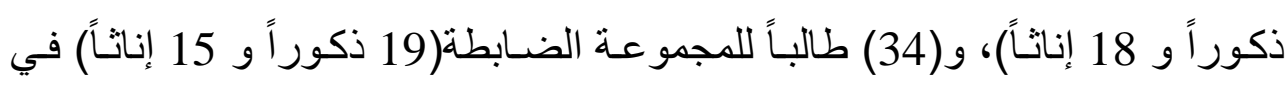
العام الدراسي الجامعي (2007/2006). وقد أظهرت نتائج الدر اسة أن طريقة التعلم

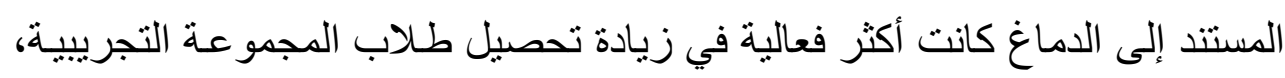
ولم يظهر أي فرق ذو دلالة بين مسنويات تحصيل الطلاب باختلاف أنماط تعلمهم.

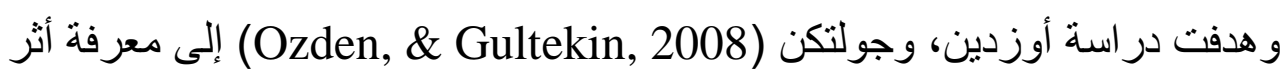
التعلم المستند إلى الدماغ على التحصيل الدراسي. ولتحقيق أهداف الدر اسة؛ تم إعداد وتطبيق اختبار تحصيلي في مادة العلوم، على عينة الدراسة المكونة من (44) طالباً

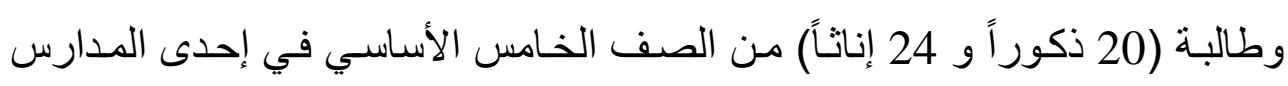


بتركيـا في العـام الدراسـي (2005/2004)، بو اقع (22) طالبـاً وطالبـة للمجموعـة

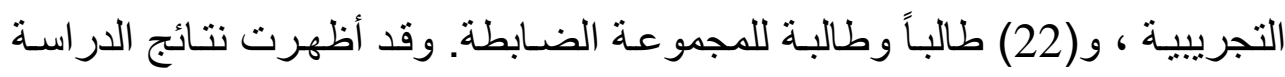

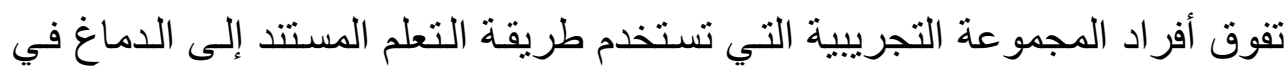

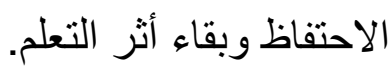
و هدفت در اسـة دومـان (Duman, 2006) إلى تقصي فاعلية التدريس باستخدام

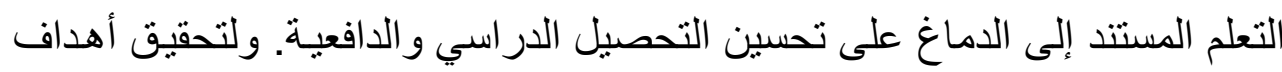

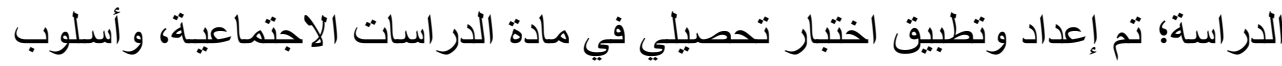

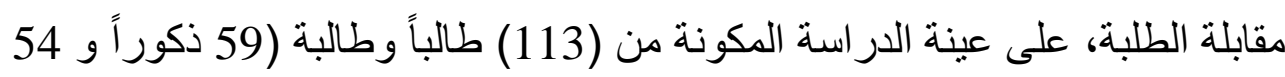
إناثاً)من الصف السادس الابتدائي في إحدى مدارس تركيا، (بو اقع39 طالباً وطالبة

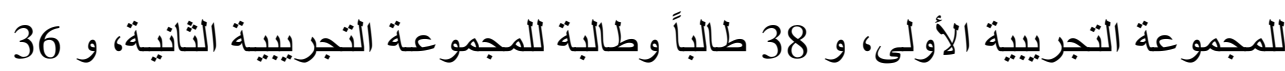

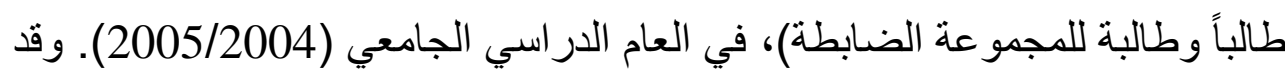

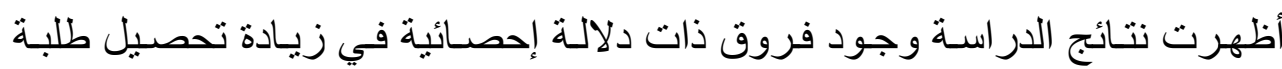

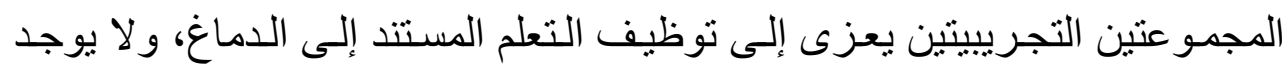
فروق ذات دلالة إحصائية في متغير الجنس. الاراسات المتعلقة بتقدير الذات هدفت در اسـة سـمارة، وسـمارة، و السـلامات (2012) إلى استقصــاء درجـة تقدير معلكي المرحلة الأساسية الدنيا لذو اتهم و علاقتها بدافعية الإنجاز لديهم. ولتحقيق

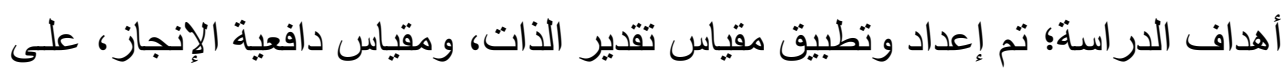

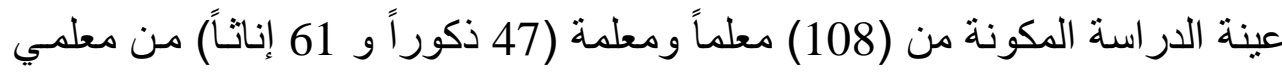

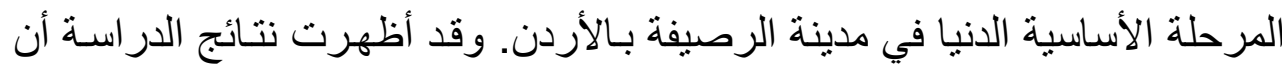
درجة تقدير المعلمين لذو اتهم كانت مرتفعة، وكذلك مستوى دافعية الإنجاز لديهم كان

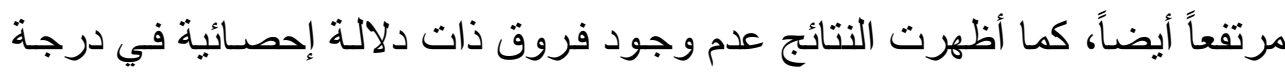
تقدير المعلمين لذاتهم، ومستوى دافعيـة الإنجاز، تعزى لمتغير الجنس، والمؤهل 
العلمي، و الخبرة التدريسية، كما أشارت النتائج إلى وجود علاقة ارتباطية موجبة بين درجة تقدير المعلمين لذواتهم ومستوى دافعية الإنجاز لايهم. و هـدفت در اسـة الحر احثـة (2012) إلـى بيـان العلاقـة بـين مسـتوى تقدير الـذات و التحصـيل الأكـاديمي. ولتحقيـق أهداف الدر اسـة؛ تـم إعداد وتطبيـق مقيـاس تقدير الذات، على عينة الدراسة المكونة من (140) طالباً (124 إمار اتي الجنسية و 16من جنسيات أخرى) من ضباط أكاديمية العلوم الثرطية للسنو ات الأولى و الثانية والثالثة بالثارقة بالإمار ات العربية المتحدة. وقد أظهرت نتائج الدر اسـة وجود علاقة ذات دلالة إحصائية لتقدير الذات على مستوى التحصبل الأكاديمي للطلبة الضباط، و عدم وجود فروق ذات دلالة إحصائية في مستوى تقدير الذات بين الطلبة الضباط تعزى لمتغيري؛ الجنسية، و المستوى الدر اسي. و هدفت در اسة دودين، وجروان (2012) إلى التحقق من أثر تطبيق بر امج التسريع و الإثـر اء علـى الدافعيـة للـتعلم والتحصـيل الدراسـي، وتقـدير الـذات لـدى الطلبـة المو هوبين في الأردن. ولتحقيق أهداف الدر اسـة؛ تـم إعداد وتطبيق مقيـاس دافعيـة التعلم، ومقياس تقدير الذات، على عينـة الدراسـة المكونـة من (182) طالبـاً وطالبـة موز عين في مجمو عتين؛ مجموعـة الطلبـة المسر عين (و عددهم (91) طالبـاً وطالبـة (45ذكوراً و 46إناثاً) في صفوف المرحلة الأساسية العليا من الصف السـابع وحتى العاثـر)، ومجموعـة الطلبـة الملتحقين في مـدارس الملك عبد اللـه الثـاني للتميـز (و عددهم (91) طالباً وطالبة (45 ذكوراً و 46 إناثاً) في صفوف المرحلة الأساسية العليا من الصف السابع وحتى التاسع). وقد أظهرت نتائج الدراسة وجود فروق ذات دلالة إحصائية لصالح الطلبة المو هوبين الذين تعرضو البرامج التسريع في مستويات الدافعية للتعلم و التحصيل وتقدير الذات، كما أظهرت النتائج عدم وجود فروق ذات إحصائية في مستوى الدافعية للتعلم وتقدير الذات تعزى لاختلاف الجنس، ووجود فروق ذات دلالة إحصائية في مستوى التحصيل الدراسي لصالح الإناث. 
وهدفت دراسـة صـرداوي (2011) إلى فحص العلاقة بين كل مـن دافع الإنجـاز وتقدير الذات والتحصيل الدراسي و الفروق بين الجنسين في دافع الإنجاز وتقدير الذات. ولتحقيق أهداف الدراسـة؛ تم إعداد وتطبيق اختبـار دافع الإنجاز للأطفال

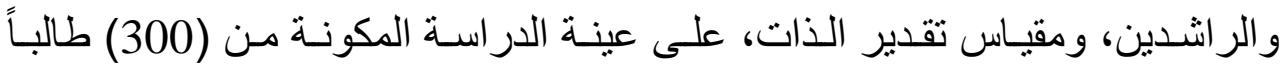

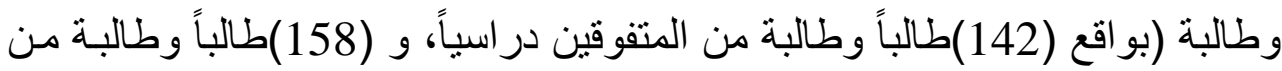
المتأخرين در اسياً) من الصف الثالث الثانوي في المدارس التابعة للمقاطعة الإداريـة و التربويـة بالدار البيضـاء في الجزائر خـلال العـام الدراسي (2005/2004). وقد أظهرت نتائج الدر اسة عن وجود علاقة موجبة دالة بين كل من دافع الإنجاز وتقدير

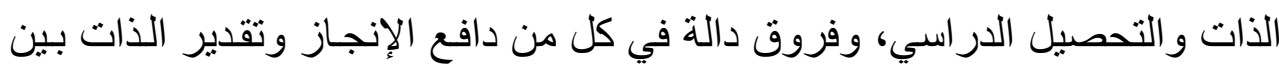

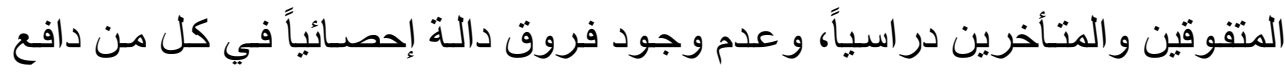
الإنجاز وتقدير الذات بين الجنسين.

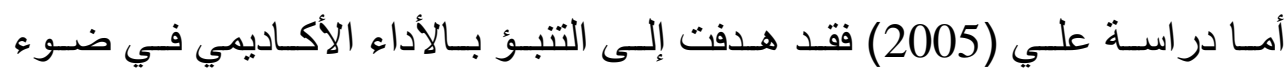
استر اتيجيات التذكر والدافعيـة للتعلم ومفهوم الذات. ولتحقيق أهداف الدر اسـة؛ تم إعداد وتطبيق قائمسة استر اتيجيات التذكر، ومقياس مفهوم الذات، ومقياس الدافعية

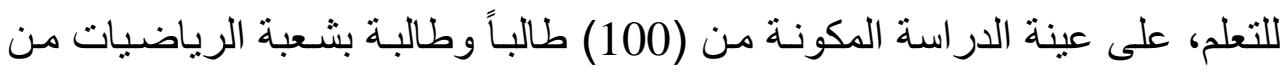
كلية التربية بيني سويف بمصر. وقد أظهرت نتائج الدر اسة وجود علاقات ارتباطية دالة إحصائياً بين متغير ات الدر اسة الثلاثة و التحصيل الأكاديمي، كما وجدت فروق

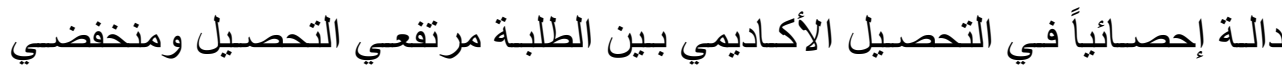
التحصيل في متغيرات الدراسة لصالح الطلبة مرتفعي التحصيل، وكذللك أمكن التتبؤ

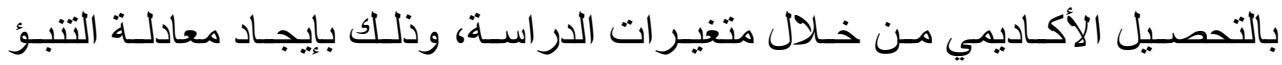

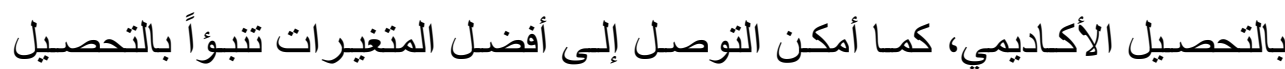
الأكاديمي وهو متغير استراتيجيات التنكر. و هدفت دراسة الفحل (2000) التعرف إلى العلاقة بين تقدير الذات ودافعية الإنجاز.

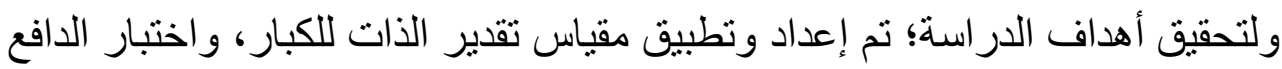


للإنجاز للأطفال و الر اشدين، على عينـة الدراسـة المكونـة من (120) طالباً (بواقع

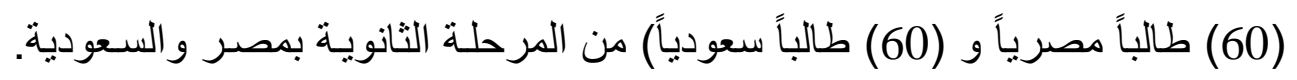

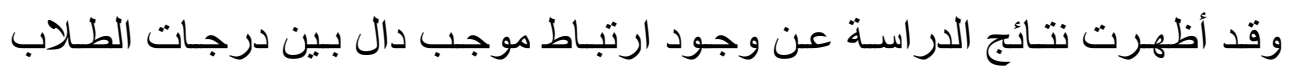
المصريين، وكذلك درجات الطلاب السعوديين في تقدير الذات ودرجاتهم في دافعية

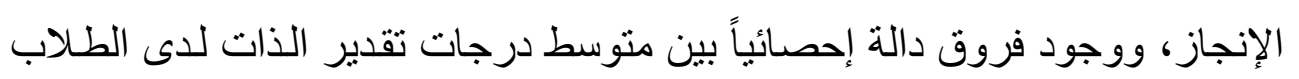

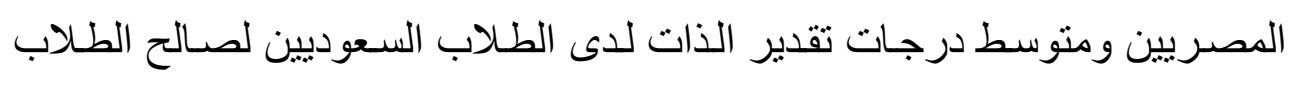
المصريين، وكذلك بينت النتائج عدم وجود فروق دالة إحصائياً بين متوسط درجئ دافعية الإنجاز لدى الطلاب المصريين ومنوسط درجات دافعية الإنجاز لدى الطلاب السعوديين. و هدفت دراسـة المطوع (1996) التعرف إلى طبيعة العلاقـة بين التوازن النفسي

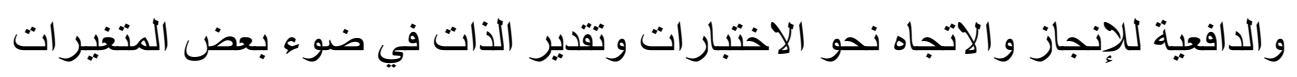

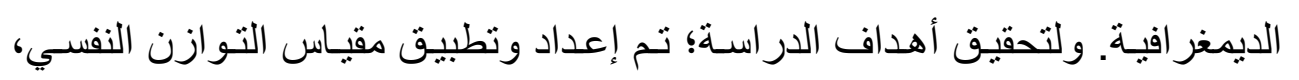

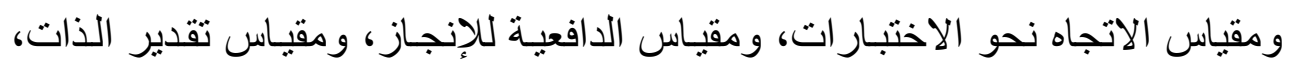

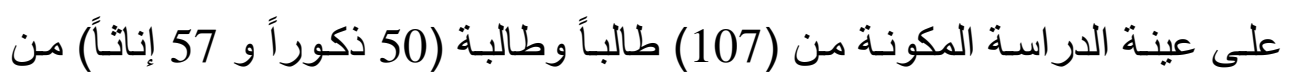

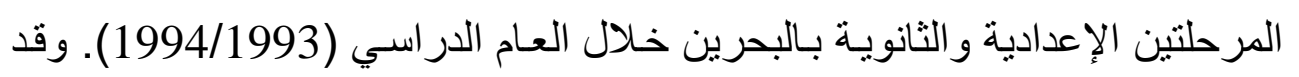

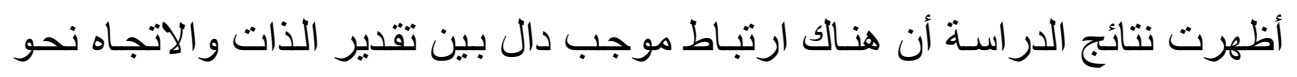

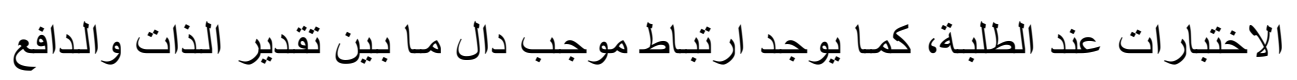

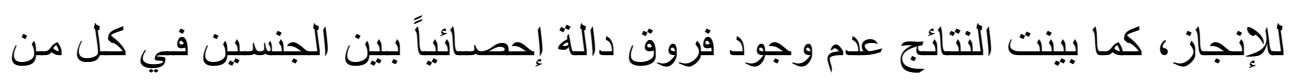

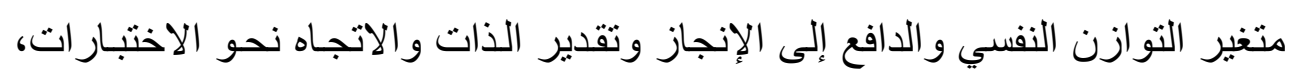

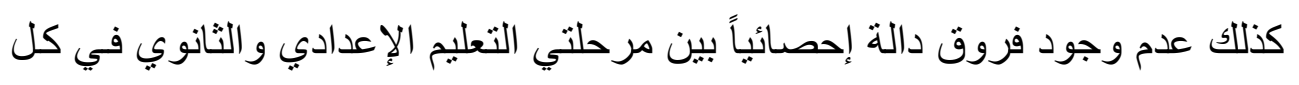

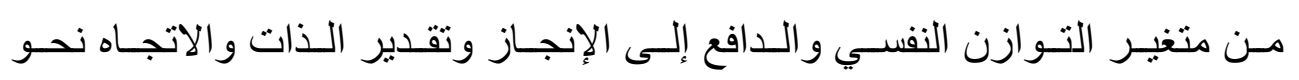

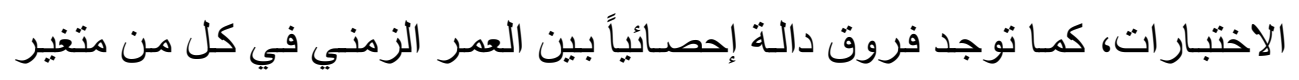

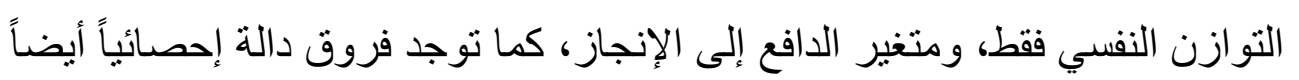

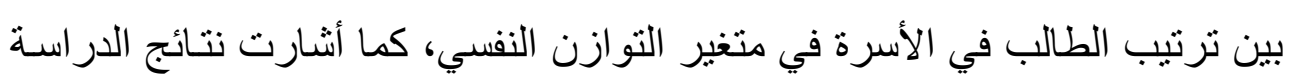


أنـه لا توجد فروق دالـة إحصـائياً بين المستوى الاقتصـادي و الاجتمـاعي في كلمن متغير التوازن النفسي والدافع إلى الإنجاز وتقدير الذات والاتجاه نحو الاختبار ات.

الاراسات المتعلقة بالاففعية للإنجاز هدفت در اسة حسن (2016) إلى تحديد القيمة التتبؤية لكل من فاعلية الذات والدافعية للإنجاز بجودة الحياة في ضوء التخصص العلمي و الأدبي. ولتحقيق أهداف الدر اسة؛ تم إعداد وتطبيـق مقبـاس فاعليـة الـذات، ومقيـاس جـودة الحيـاة، ومقبـاس الدافعيـة للإنجاز ، على عينة الدر اسة المكونة من (120) طالبة من طالبات مرحلة الدر اسـات العليا بكلية التربية بجامعة الدمام بالسـعودية. وقد أظهرت نتائج الدر اسـة أنه يمكن التتبؤ بجودة الحيـاة مـن خـلال كل من فاعليـة الذات والدافعيـة للإنجـاز ، ولم تسفر النتـائج عـن أي فـروق دالـة إحصـائياً بـين طالبـات التخصـص العلمي و الأدبـي في متغير ات الدراسـة عدا بعد جـودة إدارة الوقت وشـل أوقـات الفر اغ، حيـث كانت الفروق لصالح طالبات التخصص العلمي. و هدفت در اسة العتيبي (2014) التعرف إلى مستوى فاعلية الذات و علاقتها بدافعية الإنجاز ـ ولتحقيق أهداف الدر اسة؛ تم إعداد وتطبيق مقيـس فاعلية الذات، ومقيـاس دافعية الإنجاز ، على عينة الدر اسة المكونـة من (184) طالبـاً وطالبـة (82 ذكوراً و

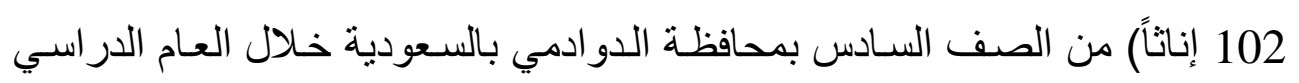
(2014/2013). وقد أظهرت نتائج الدراسـة أن مستوى فاعليـة الذات لدى الطلبـة

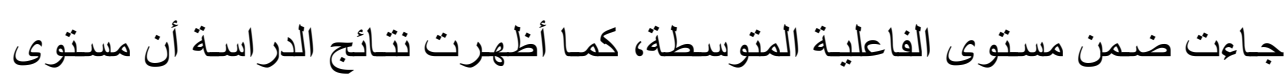
دافعية الإنجاز لاى الطلبة جاءت ضمن مستوى الدافعية المرتفعـة كدرجة كلية، كمـا

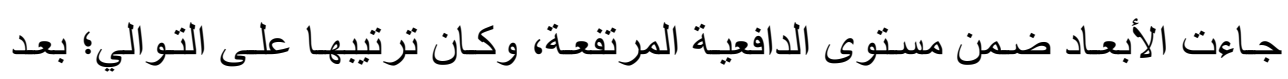
المثابرة، وبعد وجود هدف يسعى لتحقيقه، وبعد الطموح، كما أظهرت النتائج وجود علاقة ارتباطية موجبة دالة إحصائياً بين الفاعلية الذاتية وبين دافعية الإنجاز بأبعادها 
المختلفة لدى الطلبة، كما كثفت النتائج أن الجنس لا يعد عاملاً مؤثراً في العلاقة بين الفاعلية الذاتية ودافعية الإنجاز لاى الطلبة.

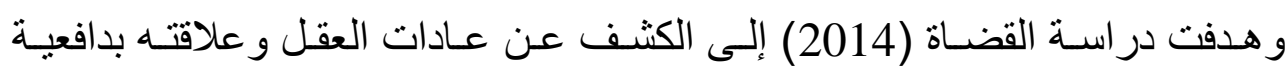
الإنجاز . ولتحقيق أهداف الدراسة؛ تم إعداد وتطبيق مقياس عادات العقل، ومقياس

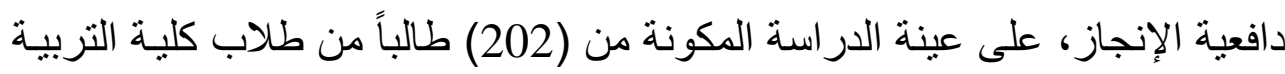

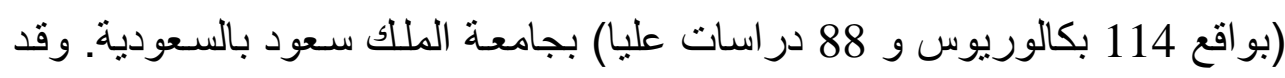

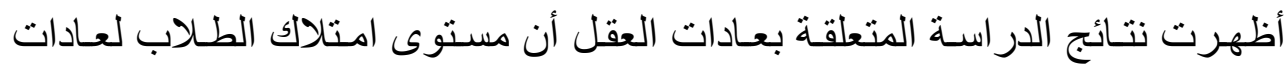

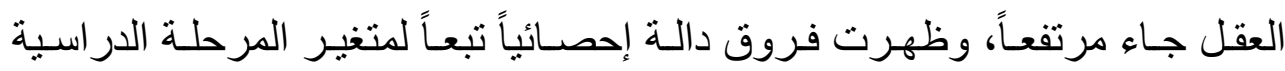

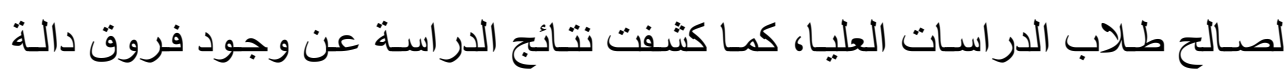

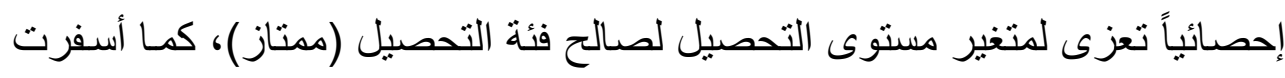

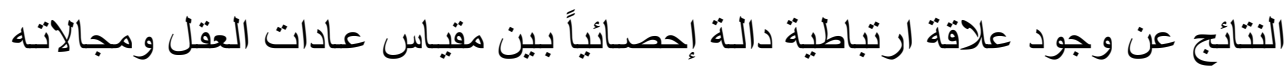

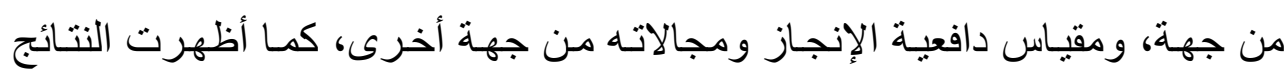

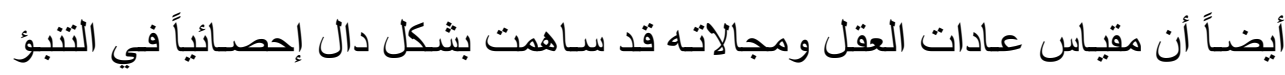
بدافعية الإنجاز. و هدفت در اسة سالم، وقمبيل، و الخليفة (2012) إلى معرفة العلاقة الارتباطية بين

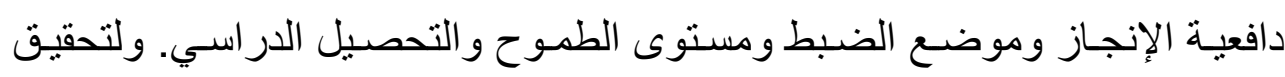

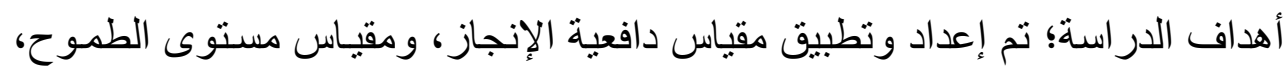

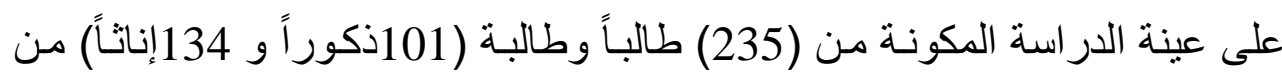

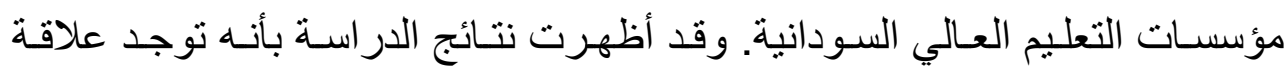
ارتباطية عكسية دالة إحصائياً بين دافعية الإنجاز وموضع الضبط، كما توجد علاقة

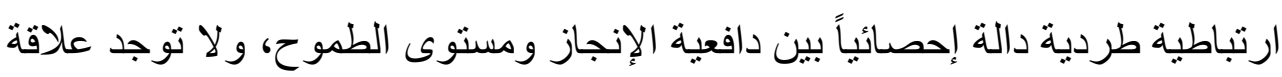

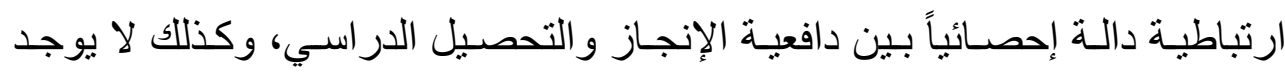

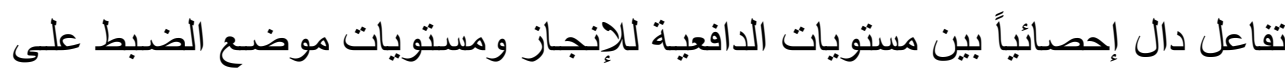
التحصيل الدراسي. 
أما در اسة إسماعيل (2008) فقد هدفت إلى تقصـي العلاقة الارتباطيـة الثنائية بين المعتقدات المعرفية، والتفكير ما وراء المعرفي، ومفهوم الذات، ودافعية الإنجاز تبعاً لمتغير (مقبول، غير مقبول). ولتحقيق أهداف الدراسة؛ قام الباحث بتكييف وتطبيق مقاييس للمعتقدات المعرفيـة، والتفكير مـا ور اء المعرفي، ومفهوم الذات، ودافعيـة الإنجـاز، على عينـة الدر اسـة المكونـة مـن (276) طالبـاً وطالبـة مـن طلبـة الصـف العاشر، و الصف الأول الثانوي؛ (بو اقع 166 تقدموا وقبلو اللدر اسة في مدرسة الملك عبد الله الثاني للتمبز في مدينة إربد بالأردن، و 110 تقدمو ا ولم يقبلو اللار اسـة في ذات المدرسة). و أظهرت نتائج الدر اسة تقارب في الدرجة التي حصل عليها كل من الطلبـة المقبولين و غير المقبولين على كل مقيـاس من مقاييس الدراسـة، كمـا بينت وجود فروق ذات دلالة إحصائية في العلاقة الارتباطية الثنائية بين متغير ات الدر اسة بجميع مجالاتها وكانت لصـالح الطلبة المقبولين باستثناء مجالي (السلطة المطلقة، ومحسوس متسلسل)، وعدم وجود أي فروق دالة إحصائياً في العلاقة الارتباطية بين المعتقدات المعرفية ومجالاتها والتفكير ما وراء المعرفي ومجالاته من جهة، ومفهوم

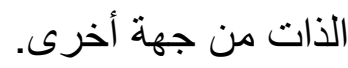
و هدفت در اسـة المـزروع (2007) إلى الكثـف عن علافة فاعليـة الذات بكل مـن الدافع للإنجاز و الذكاء الوجداني. ولتحقيق أهداف الدر اسة؛ تم إعداد وتطبيق مقياس فاعلية الذات، ومقياس مستوى الإنجاز ، ومقياس الذكاء الوجداني، على عينة الدراسة المكونـة مـن (238) طالبـة مـن جامعـة أم القـرى بالسـعودية خـلال الفصـل الثـاني للعامالدر اسـي الجـامعي (2005/2004). وقـد أظهـرت نتـائج الدر اسـة عـن وجـود ارتباط إيجابي ذي دلالة إحصائية بين درجات فاعلية الذات، وكل من درجات دافعية الإنجاز ، و الذكاء الوجداني بأبعاده المختلفة، ووجود فروق ذات دلالة إحصـائية بين درجـات الطالبـات مرتفعـات ومنخفضـات دافعيـة الإنجـاز في درجـة فاعليـة الـذات لصالح مرتفعات الإنجاز ، كما أظهرت وجود فروق ذات دلالة إحصائية بين درجات 
الطالبـات مرتفعـات ومنخفضـات الذكاء الوجداني في درجـة فاعلية الذات لصـالح

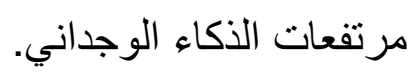
تعقيب على الدراسـات السـابقة المتعلقة بالتعلم المستند إلى الدماغ، وتقدير الذات، والدافعية للإنجاز ، وموقع الدر اسة الحالية منها:

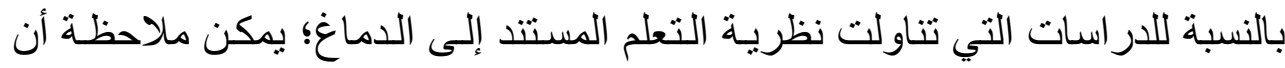

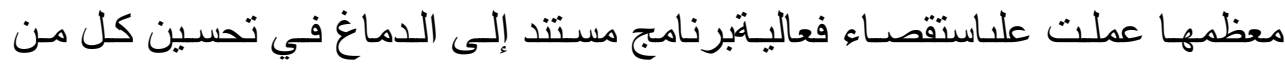

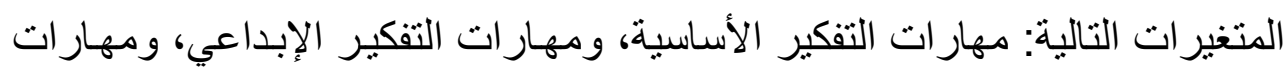
التفكيـر التـأملي، و الكفــاءة الذاتيـة المدركـة، وعـادات العقل، و الدافعيـة للإنجـاز (الدر اسي)، و الدافعية للتعلم، و عادات الاستذكار، و التحصيل الدر اسي (الأكاديمي)،

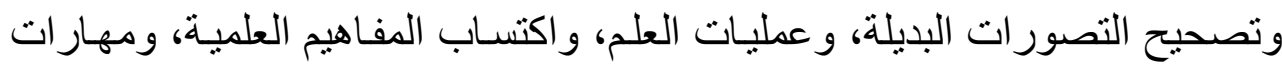
التواصل الرياضي، وتنظيم الذات، وتقدير الذات.

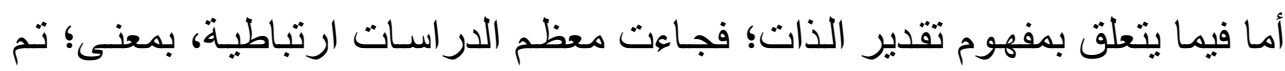

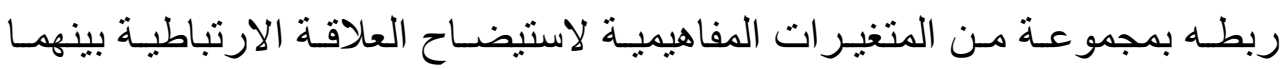

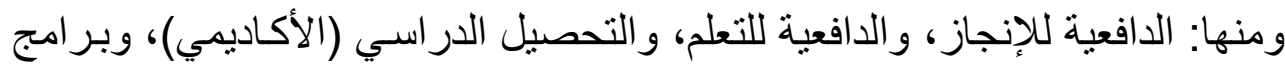
التسريع والإثراء، و التوازن النفسي، والاتجاه نحو الاختبارات.

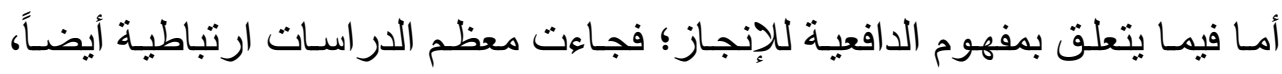
بمعنى؛ تم ربطه بمجمو عة من المتغيرات المفاهيمية لاستيضـاح العلاقة الارتباطية بينهما ومنها: التفكير ما وراء المعرفي، والتفكير الإبداعي، وأنماط التعلم المستندة

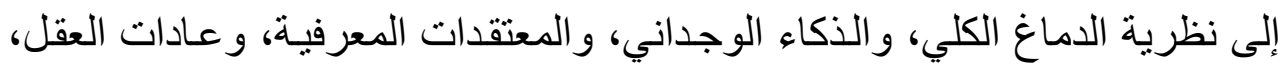

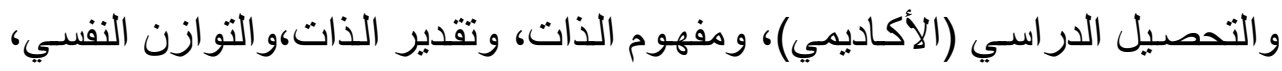

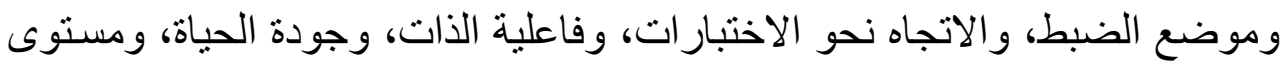

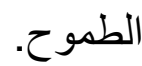
أما من حيث العينات المستخدمة في هذه الدراسات؛ فجاءت متنوعة، فشملت: أطفال الروضة، وطلبة الصفوف من الثالث الأساسي (الابتدائي)، ولغاية العانشر الأساسي، 
و الأول المتوسط، وطلبة المرحلة الإعدادية، وطلبـة المرحلة الثانويـة (ومنهـا الصف الأول الثانوي، و الثالث الثانوي)، و الطلبة الجـامعيين (مرحلة البكالوريوس)، وطلبة الدر اسات العليا، و المعلمين، ذكوراً و إناثاً. أما من حيث المنهجيـة، فقد تعددت المنهجيات المستخدمة؛ فكانت: إمـا وصفية، أو تجريبية. أمـا مكـان إجـر اء الدر اسـات فكانــت منتو عـة؛ إذ أجريــت في الأردن، والسـعودية، و مصـر ، وسـلطنة عمـان، و الإمـار ات، والبحـرين، و السـودان، والجز ائـر، وتركيـا، وباكستان. جاءت هذه الدر اسة لتختبر فعالية برنامج تدريبي مبني على نظرية التعلم المستند إلى الدماغ في تحسين تقدير الذات و الدافعيـة للإنجاز ؛ هذا الربط تـم التطرق إليـه سـابقاً وبشكل محدود جداً - حسب علم الباحثـ ليشكل إضـافة نوعيـة لهذه الموضـوعات المهمة. وكذلك تبين أن العينة المستخدمة في هذه الدراسة كانت من طالبات الجامعة ضمن مرحلة البكالوريوس، حيث جاءت كنوع من اهتمـام الباحث و اتصـاله المباشر بهن، لينعكس ذلك على الفهم العـام للعلاقة السببية بين نظريـة التعلم المستند إلى الدماغ، وتقدير الذات، و الدافعية للإنجاز ، هذا وقد استخدمت هذه الدر اسة أسلوباً شبه تجريبي. وتجدر الإشارة إلى أن الباحث قد استفاد من الدراسـات السـابقة في تحديد مشكلة الدر اسة، و أهدافها، و إعداد فرضياتها، وبرنامجها، ثم تفسير النتائج. التعريفات النظرية: - مانة

أولاً: التعلم المستند إلى الدماغ (Brain based learning) يعرف شنك (Schunk, 2012) التعلم بأنه تغير دائم في السلوك، أو في القدرة على

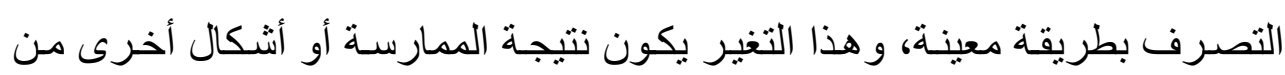
الممارسة. بينما يعرف جينسن (2007) التعلم المستند إلى الدماغ بأنه ذلك التعلم المبني على وظائف وقدرات الدماغ، و الذي يتو افق مع الطريقة الطبيعية التي يتعلم بها الدماغ، إذ 
أنها طريقة تجمع عدة فروع علميـة (علم الكيمياء، و علم الأعصـاب، وعلم النفس، و علم الاجتماع، و علم الجينات، و علم الأحياء، وعلم إحصائيات الأعصاب الحيوية)، و مبنية على السؤال الأساسي الآتي: ما الثيء المناسب للدماغ؟، حيث أنها بمثابـة رؤية عن التعلم، وليس فرعاً من العلوم مستقلاً بذاته، وليست نمطاً أو أسلوباً جامداً وقالباً يصلح لحل جميع المشكلات. إذاً يُعنى فرع التعلم المبني على وظائف وقدر ات الدماغ بكيفية الوصول لأفضل طريقة يتعلم بها الدماغ. و لا يتعلم الدماغ طبقاً للجدول المدرسي الصـارم غير المرن، بل لديه إيقاعه الخاص.

ثانياً: تقدير الذات (Self-esteem) يعرف هيثرتون، ووايلاند (Heatherton, \&Wyland, 2003) تقدير الذات على

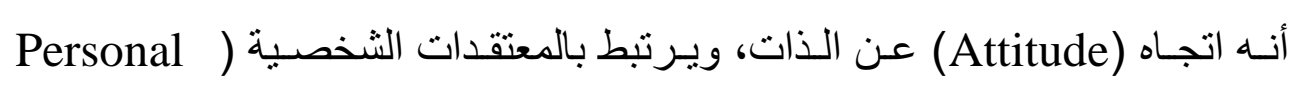
beliefs حول المهار ات (Skills)، و القابليات/ القدرات (Abilitties)، و العلاقات الاجتماعية (Social relationships)، و النتائج المستقبلية (Duture outcomes). ويعرفه مالهي، وريزنر (2006) على أنه تقييم الفرد الكلي لذاته إما بطريقة إيجابية أو سلبية. أما ميز اب (2013) فيعرفه بأنه ذلك الجزء الوجداني من تكون الذات، وله

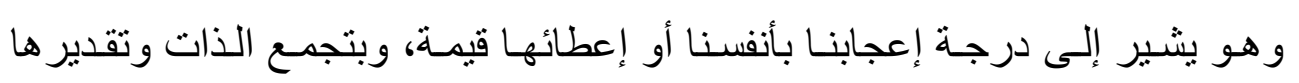
ومفهومها تكون الشخصية، فعند الحديث عن تقدير الذات فإننـا نشـير إلى حكم الشخص بأهمية نفسه أو عدم أهميته وبتقبل الآخرين أو عدم تقبله لهم، و الذي يعبر عنه الفرد بما لايه من اتجاهات نحو نفسه بالاستحسان أو الاستهجان، كما يشير إلى بلى درجة اعتقاد الفرد في نفسه وبقدرته وأهميته ونجاحه وقيمته. وتعرف سليم (2003 أ) تقدير الذات بأنـه الميل إلى النظر إلى الذات على أنها قادرة على التغلب على تحديات الحياة و أنها تستحق النجاح و السعادة، كما أنه مجموع المشـاعر التي يكونها الفرد عن ذاته بما في ذلك الثـعور بـاحتر ام الذات وجدارتها. ويسـاوي تقدير الذات الشعور بالرضا الذي ينشأ عند الفرد نتيجة تلبية حاجاته، وكذلك فإن تقدير الذات هو ما يعتقده الفرد ويشـر بـه إزاء صـورته عن نفسـه، وتقدير الذات هو أيضـاً إدراك 
الفرد لأهميتهـ التي تدفعـه إلى التصـرف بمسؤولية إزاء نفسـهـ و الآخرين. وتعرفـه

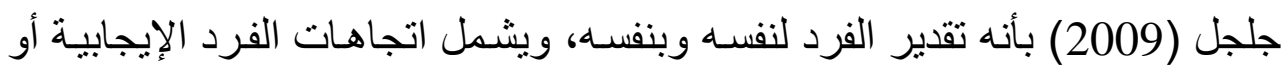
السلبية نحو ذاته، ومعتقداته، ونجاحه أو فثنله، و التي ينقلها للآخرين. ويعرف الرشيدي، وأبو علام، والجبر، والهاجري (2004) تقدير الذات بأنه احتر ام

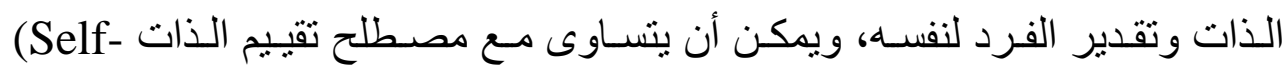

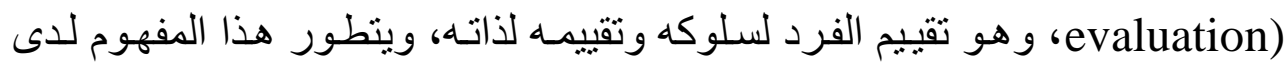

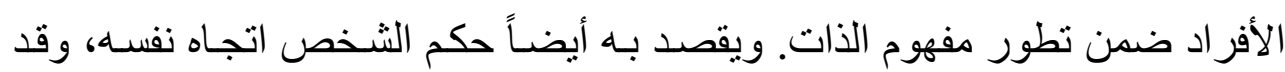

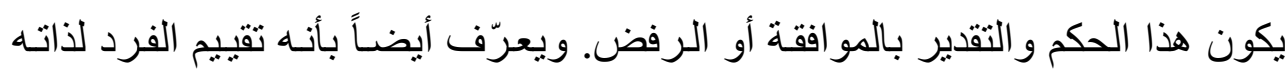

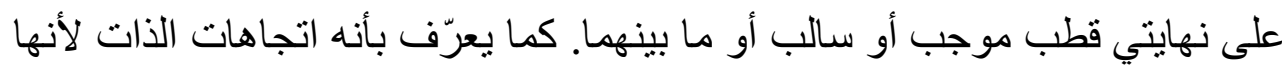

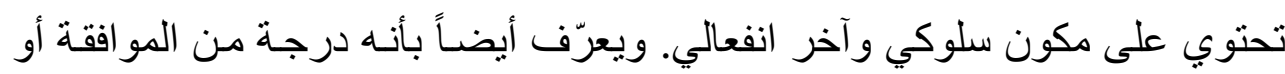

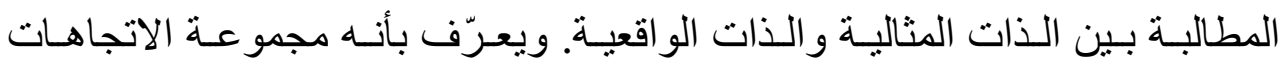
و المعتقدات التي يستدعيها الفرد عندما يو اجه العالم المحيط به، وهي تثمل معتقدات

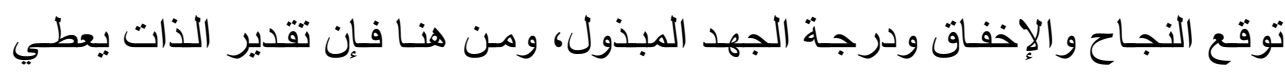
تجهيزاً عقلياً يعد الفرد للاستجابة طبقاً لتوقعات النجاح و القبول و القوة الثخصية. ثالثاً: الدافعية للإنجاز (Achievement motivation)

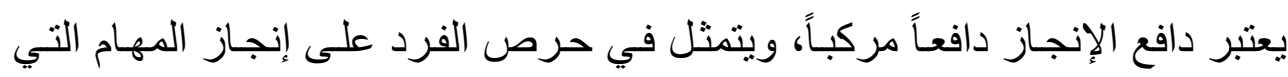

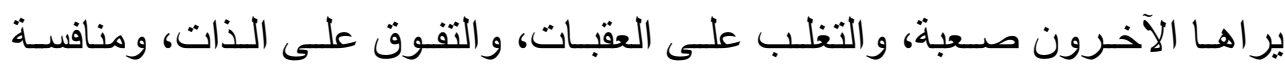
الآخرين والتفوق عليهم. ويعر فه أتكنسون (Atkinson) بأنه استعداد ثابت نسبياً في

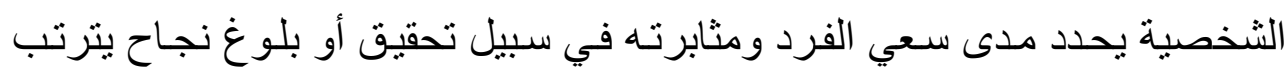

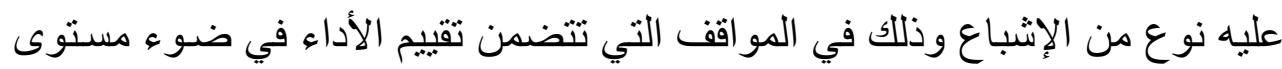

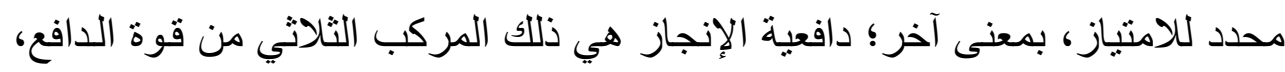

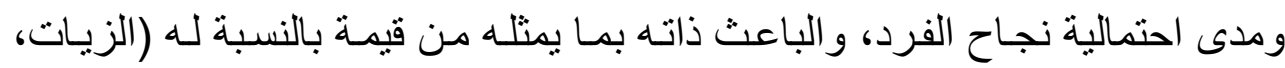


و أما ماكليلاند (McClelland) فقد عرف الدافع للإنجاز بأنه استعداد ثابت نسبياً في الثخصية يحدد مدى سعي الفرد في سبيل تحقيق وبلوغ نجاح يترتب عليه نوع من الإرضاء، وذلك في المو اقف التي تتضمن تقييم الأداء في ضوء مستوى فئو محدد من

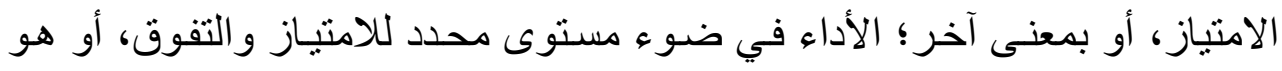
ببسـاطة الرغبة في النجاح و السعي للحصول عليه (أبو حطب، وصـادق، 2009)

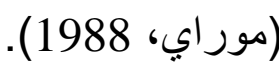
أما الزيات (2004) فيعرفه بأنه دافع مركب يوجه سلوك الفرد كي يكون ناجحاً في

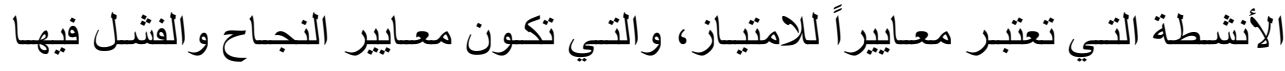
واضحة ومحددة. ويشير أبو علام (2004) إلى أن ما يقصد بدافع الإنجاز هو أنه حالة داخلية مرتبطة بمشاعر الفرد وتوجه نشـاطه نحو التخطبط للعمل وتنفيذ هذا التخطيط لما يحقق مستوى محدداً من التفوق يؤمن بـه الفرد ويعتقد فيه. أمسا خليفة

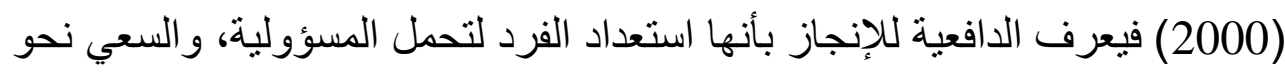

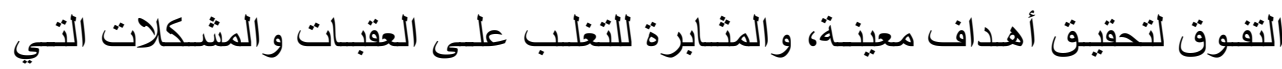
تو اجها، والثتعور بأهمية الزمن، والتخطيط للمستقبل. أما عسكر، و القنطار (2005)

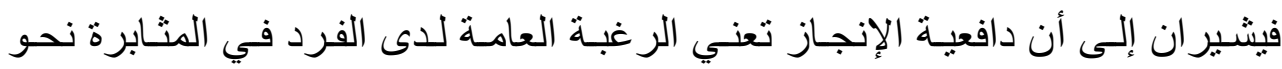

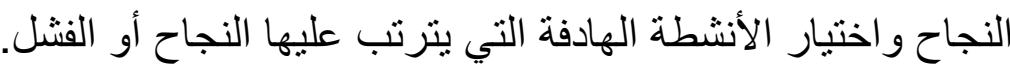
ويستخلص عبد الله (2003) من التعريفات المختلفة التي قدمت لدافعية الإنجاز عدداً

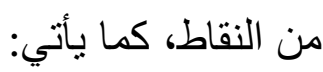
ـ الدافع للإنجاز دافع إنساني معقد أو مركب يتسم بالطموح و المتعـة في المنافسـة، و الاستقلال، وتفضيل المخاطرة، والحرص على تحقيق الأشياء الصعبة أو التحكم في الأفكار مع حسن تناولها وتنظيمها .

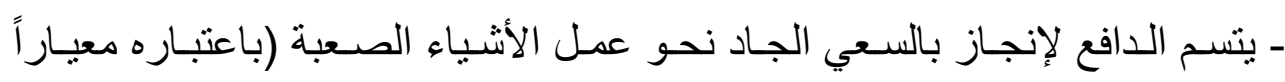

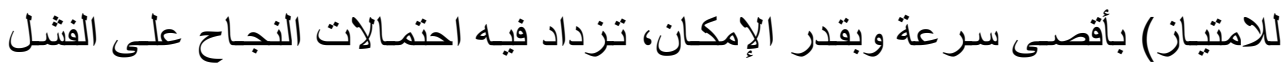
ويتجه مباثرة نحو تحقيق الهدف. 
- يرتبط الدافع للإنجاز بأهداف منجددة تتعلق بنمط الحضارة التي يعيش فيها الفرد.

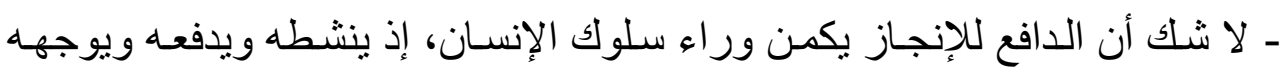

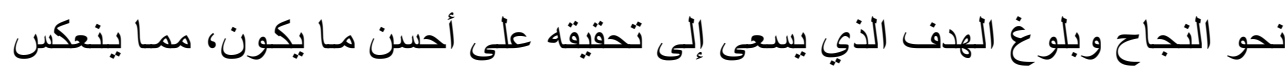

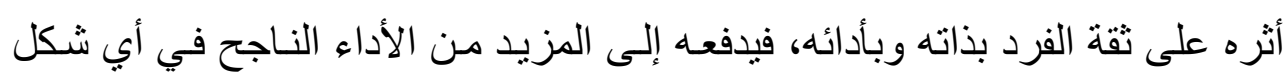
من أنثكال النشاط الإنجازي.

- يُكتسب الدافع للإنجاز في مرحلة مبكرة من عمر الفرد، ويُدعم من خلال استحسان

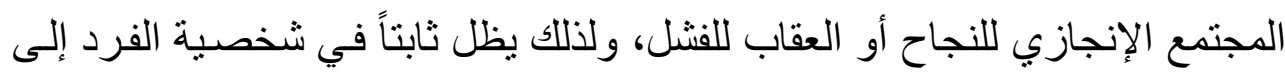

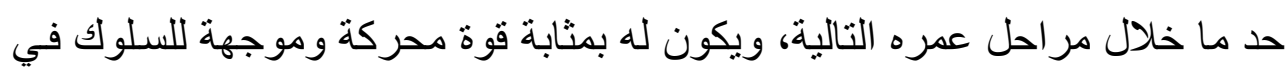
آن واحد. - يـدفع الدافع للإنجـاز الفرد إلى العمل المضنـي و الجـاد لتحقيق النجاح، والأفر اد

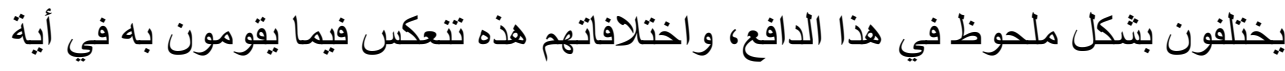

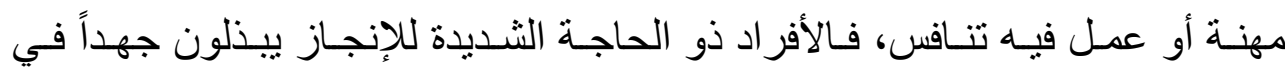

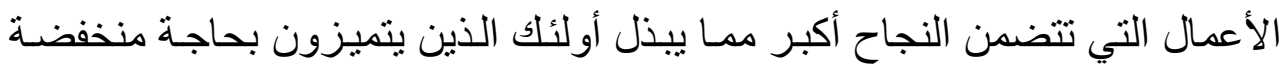
للإنجاز، و لا شكك أن هذه الفروق هي سبب نجاح كثير من الناس فيما يقومون به.

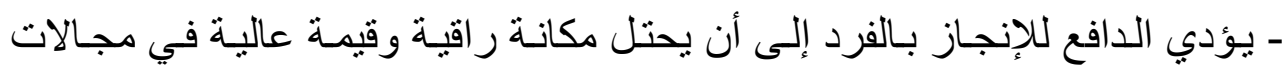
الإنتاج و الإبداع، والفرد الذي يضع الإنجاز هدفاً شخصياً له؛ هو الذي يلتمس معياراً

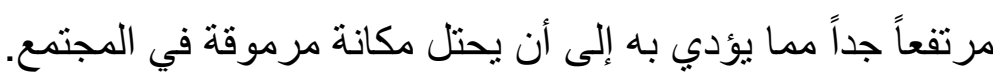

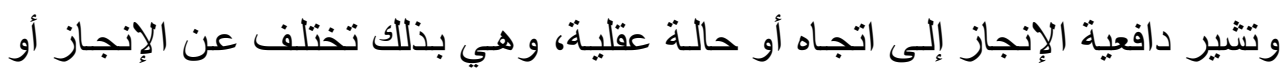

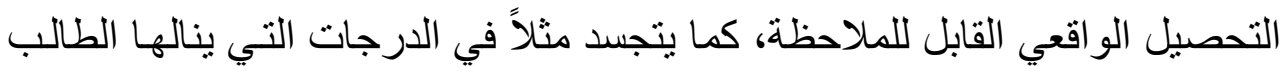

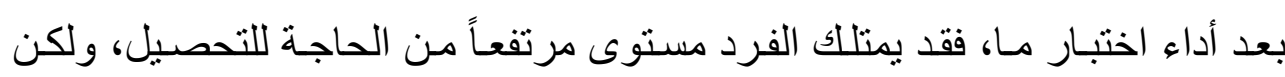

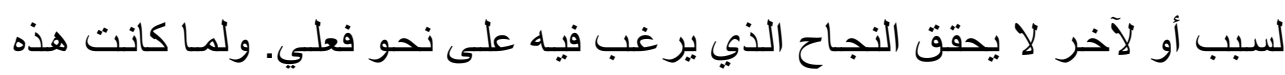

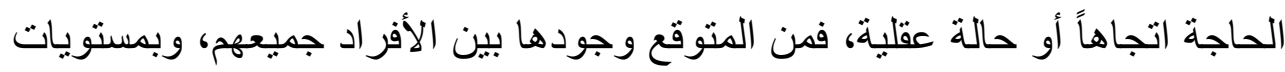
متباينة يمكن قياسها والتعرف إليها (نشواتي، 2002). 


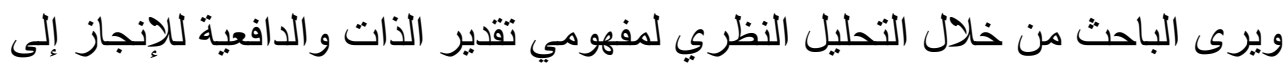
أنهما متداخلان نظرياً، والذي يير هن على ذلك أنهما يتشكلان عبر مر احل التطور

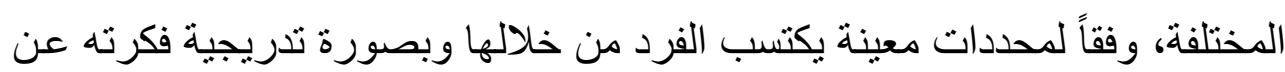
دو افعه الإنجازية وتقدير اته لذاته. وبمعنى آخر فإن الأفكار و المشـاعر و الاتجاهات

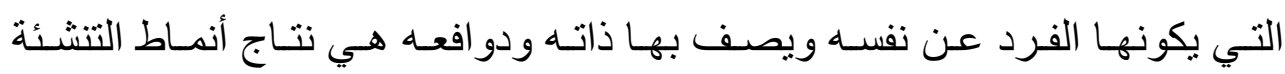

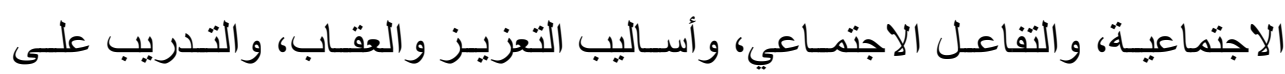

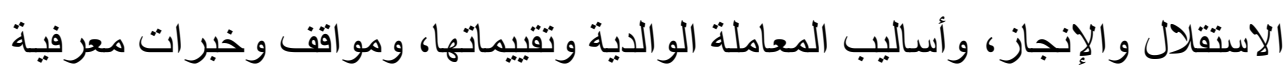

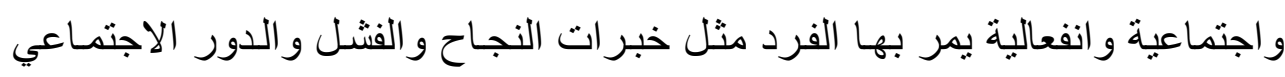

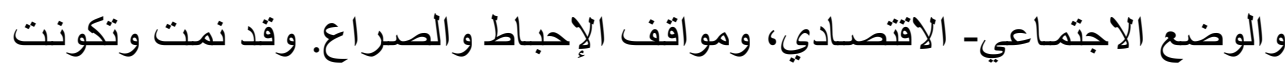

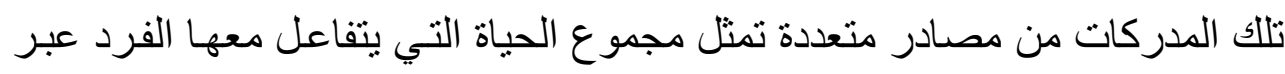
ارتقائه النفسي و الاجتماعي و العقلي و الجسمي، وبالإضافة إلى ذلك؛ تعتبر الخبرات

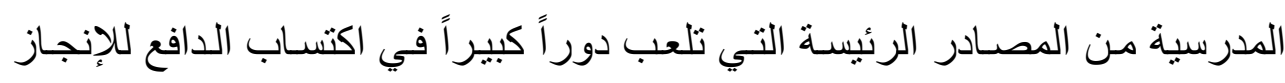
وتقدير مفهوم الذات، حيث يمر الفرد بخبرات وظروف ومواقف و علاقات جديدة،

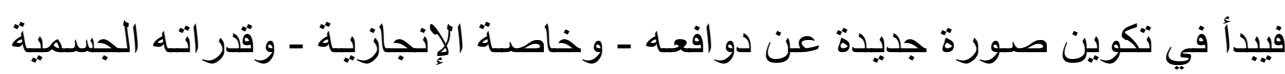

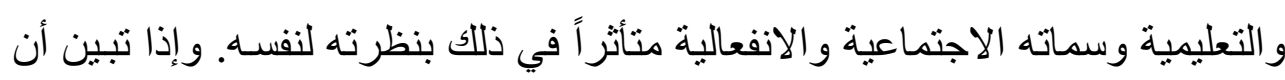

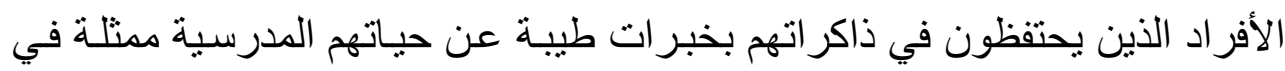
علاقة منو افقة مع المدرسين و الزملاء وتحقيق مسنويات مرتفعة من الإنجاز ؛ فإنهم يتصفون بمفاهيم وتقدير ات ايجابية عن ذو اتهم. بالإضافة إلى ذللك، يتضمن مفهوم تقدير الذات على بعض أبعاد الدافعية للإنجاز مثل بهن

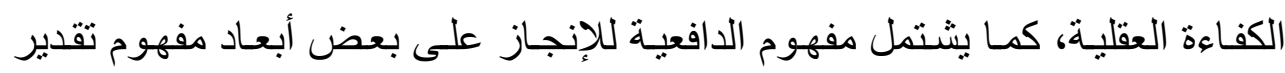

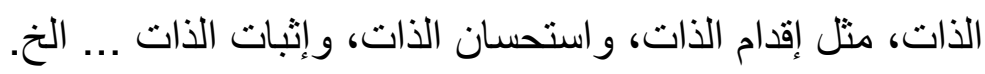
وهذا مـا أنشار إليه أندرمان، وأندرمان (2016) إذ أن معتقدات الطلبة عن أنفسهم

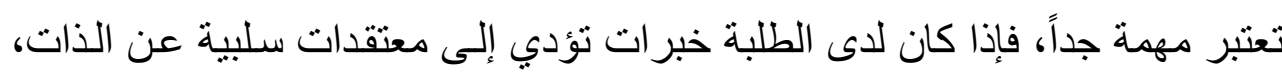
إذ تعد هذه من أوجه القصور في مشاعر الطلبة عن أنفسهم وقدر اتهم، ولها تأثيرات 
معوقة لعدد من العو امل الأكاديمية الأخرى ومنها الدافعية للإنجاز ، و العكس صحيح. ويعرف تقدير الذات - بصفة عامـة ـ في إطسار مشـاعر الفرد عن نفسـهـ وشـور الأفر اد بتقدير الذات يكون مبني على كيف يشعرون بأنفسهم بصفة عامـة. و إنـه من المهم أن يكون لدى الطلبة إحساس عـالي بتقدير الذات، رغم ذلك، لا يحل تقدير الذات العالي مشكلات أكاديمية واجتماعية نواجهه. وكذلك فإن المعتقدات عن الذات مهمـة في المجـال التربوي، وفي المواقف الأكاديميـة؛ إذ ترتبط المستويات العاليـة للكفاءة الذاتية على نحو أكثر بالتعلم الفعال والتحصيل. ورغم أن تقدير الذات العـام متغير نفسي مهم، إذ يرتبط بقوة بالتحصيل الأكاديمي عندما يكون عالياً، والعكس صحيح. وكذلك يعتبر تقدير الذات نـاتج مهم ومتغير تـابع في التربية، إذ أنه إذا تم معالجة تكوينات دافعية على نحو صحيح، قد تتنج فوائد أكاديمية ومجتمعية مرغوبـة ونو اتج ايجابية؛ عادة ما تكون مرتبطة مع تقدير ات الذات. وهذا مـا تلخصـه جلجـل (2009) في توضيح العلافـة بـين تقدير الذات و الدافعيـة للإنجاز ، فكلما كان الفرد أكثر إنتاجيـة وفعالية، كلمـا كان تقديره لذاته مرتفعاً، لأن كـلاً منهمـا سـبب ونتيجـة للآخر ، وكذلك النجـاح في مجـالات الحيـاة ومنهـا الحيـاة الأكاديمية التي تمنح الفرد ثقة بالنفس، وتقدير ذات مرتفع.

\section{التعريفات الاجرائية: - ت إن}

تضم الدر اسة اثنين من المفاهيم النظرية ترجمت إجر ائيا كما يأتي: تقدير الذات: وهو إظهار المهار ات المتضمنة في البرنـامج من خـلال مواقف عملية سبعرضها الباحث على المتعلمين، وهذا يتمثل في أداء الطالبات على مقياس تقدير الذات المعد لهذه الغاية. الدافعيـة للإنجـاز: وهو إظهار المهار ات المتضـمنة في البرنـامج من خـلال مواقف عملية سيعرضها الباحث على المتعلمين، وهذا يتمثل في أداء الطالبات على مقياس الدافعية للإنجاز المعد لهذه الغاية. 


$$
\text { حدود ومحدات الاراسة }
$$

الحـدود الموضـوعية: اسـتخدم الباحـث المـنهج شـبه التجريبـي للإجابـة عـن أسـئلة الدر اسة. الحدود الزمانية: طبقت هذه الدر اسة خلال الفصل الدراسي الأول من العـام الجـامعي .(2017/2016) الحدود البشرية: اقتصرت الدر اسة على طالبات كلية الأميرة عالية الجامعيـة/ جامعة البلقاء التطبيقية. محـددات الدر اســة:تتحدد نتــائج هـذه الدر اسـة علـى مـدى صــدق وثبـات الأداتـين المستخدمتين في جمع البيانات.

\section{منهج الاراسة} استخدم الباحث المنهج شبه التجريبي كونـه الأنسب للتحقق من فرضيات الدراسـة، حيث يقوم على تطبيق البرنامج التدريبي واعتباره متغيراً مستقلاً، لمعرفة أثره على ليى مفهومي تقدير الذات، و الدافعية للإنجاز ، و اعتبار هما متغير ان تابعين.

أفر اد الاراسة تم اختيـار أفر اد الدر اسـة بشـكل قصـدي، حيـث تـم تطبيـق البرنـامج على طالبـات البكالوريوس في التربيـة الخاصـة نظر اً لأن معد هذه الدر اسـة يعمـل في قسم علم النفس و التربية الخاصة في كلية الأميرة عالية الجامعية، ويقوم بتدريس مسـاق علم النفس التربويلطالبات مرحلة البكالوريوس في هذا التخصص. هذا وقد كانت عينة الدر اسـة ضـمن مستوى السـنة الأولى و الثانيـة، وكـان مجموع عينـة الدر اسـة (75) طالبة. وقد تم اختيار شعبة من الشعبتين التي يقوم الباحث بتدريسهم بشكل عشوائي، حيـث تكونـت المجموعـة التجريبيـة مـن (40) طالبـة، أمـا الثـعبة الأخرى فكانـت اته المجمو عة الضابطة التي تكونت من (35) طالبة. 


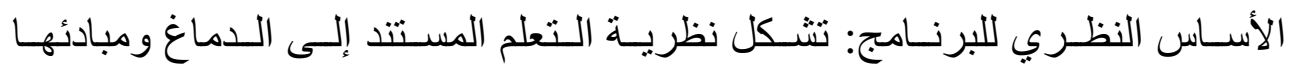
و استر اتيجياتها الأساس النظري للبرنامجالتنريبي في هذه الدر اسة.

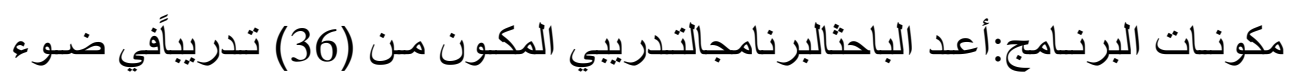

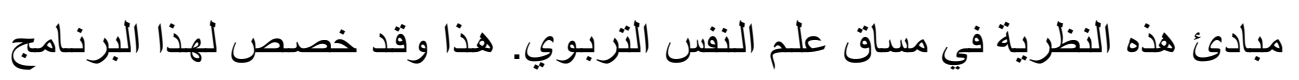

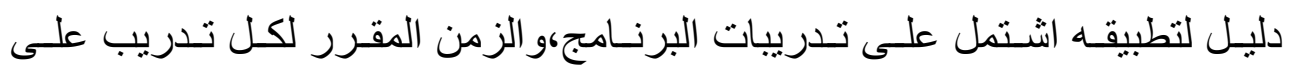

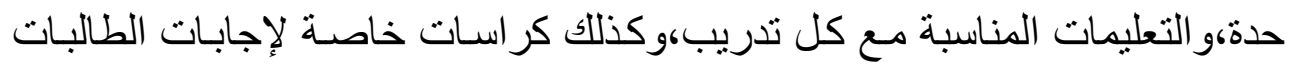

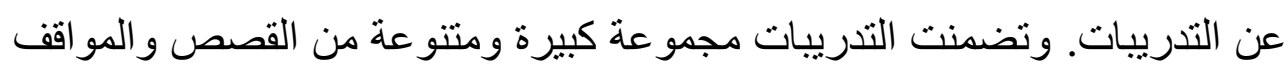

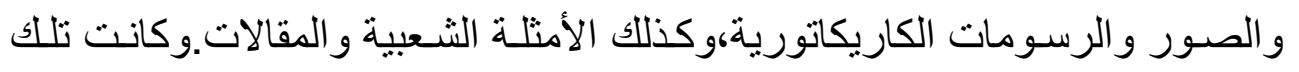

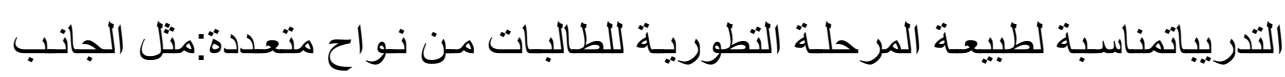
المعرفي و الاجتماعي و الانفعالي...، وطبيعة المساق الدراسي.

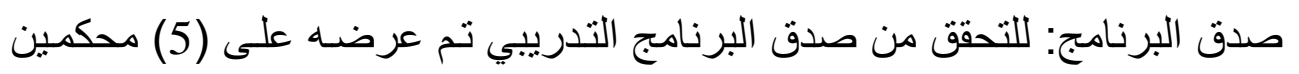

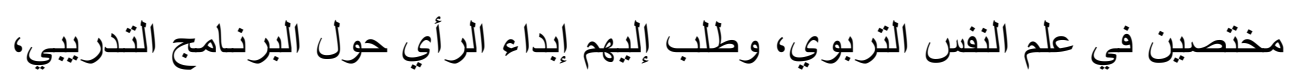

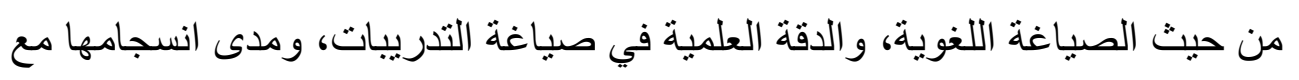
نظرية التعلم المستند إلى الدماغ. وبعد ذلك تم الأخذ باقتراحات المحكمين و آرائهم وأجريت التعديلات المقترحة على البرنامج التدريبي، وفي ضوء آلى آراء المحكمين تم التأكد من الصدق الظاهري وصدق المحتوى للبرنامج التدريبي.

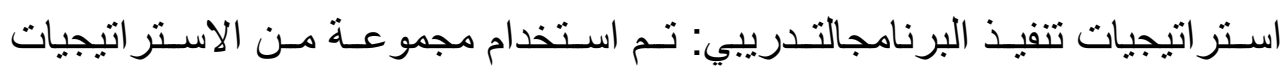

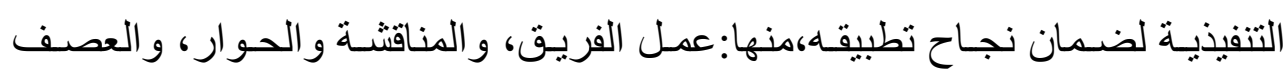

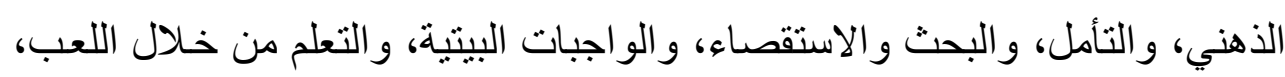
و التعلم من خلال المشرو عات، واستخدام الإنترنت. 
مدة تطبيق البرنامج: استغرق تتفيذ تطبيق البرنـامج التدريبي (12) أسبوع تقريباً

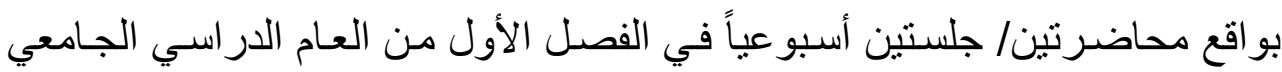
.(2017/2016)

ثانياً: لقياس تقدير الذات، والدافعية للإنجاز ؛ استخدم الباحث:

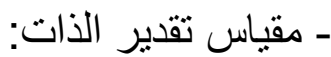

وصف المقياس: تم استخدام مقياسروزنبر غلتقدير الذات (Rosenberg, 1965) الذي ترجمه جر ادات (2006)، حيث يتألف المقياس من (10) فقرات تقبس البعد الأحسادي لمكون تقدير الذات العـام (Global self- esteem) للدى المـراهقين و الر اشـدين، ويطلب مـن المفحوصـين تقدير اسـتجاباتهم على سـلم تقدير ليكرت الرباعي؛ تتر اوح من أو افق بثدة وتعطى (4) درجات، و أو افق (3) درجات، ولا أو افق (2)، و لا أو افق بشـدة (1)، وتتر اوح درجـات المقياس الكلية من (10-40) درجة، وتثير الدرجات الأعلى إلى مستوى أكبر من تقدير الذات. ولضبط تحيز

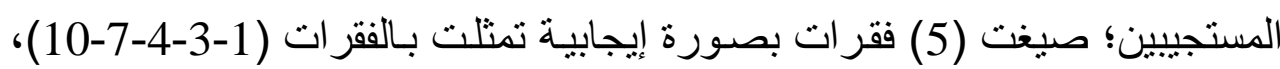
و (5) فقر ات بصورة سلبية تمثلت بالفقر ات (2-5-6-8-9). صدق المقياس:استخرج جر ادات (2006) صدق محتوى للمقياس؛ بعرض النسخة الأصلية والمترجمـة من المقياس على (5) من بين المتخصصين في علم النفس التربوي للاطلاع على وجهات نظر هم فيما يتعلق بدقة الترجمة، ومر اجعة الصياغة

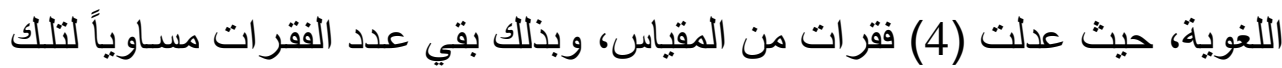

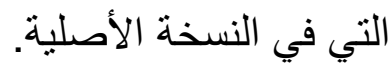
وتم حساب الصدق التلازمي للمقياس بصورته الأصلية (Rosenberg, 1965) من خـلال حسـاب معـاملات الارتبــاط بـين المقيــاس ومقيــاس الاكتئــاب لروبنـز ، و هيندن،وترزينويسكي (Robins, Hendin, \&Trzesniewski, 2001) حيث بلغ (0.34)، ومقيـاس مفهوم الـذات بأبعـاده (الأكاديميـة، و الاجتماعيـة، و الانفعاليـة، 
و البدنيــة) لجارسـيا وميوســت (Garcia,\&Musitu,2001) وتر اوحست هـــه المعاملات ما بين (0.28-0.50) الواردة في منصور (2012).

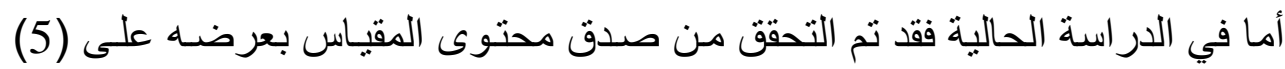

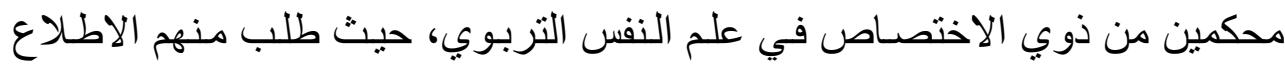
على المقياس و إبداء الملاحظات حوله، من حيث مناسبة الفقرات للفئة المستهدفة، ووضوح المعنى، وائة ملاحظات أخرى مناسبة، وتم الاجماع على سلامة الصياغة ووضوحها ومناسبتها لعينة و أهداف الدر اسة. ثبـات المقياس:استخرج جر ادات (2006)معامل ثبـات الاتسـاق الداخلي للمقيـاس، وذلك بتطبيق معادلة كرونباخ ألفا على درجات أفر اد العينة، وقد أظهر الدقياس انساقاً داخلياً مقبو لاً حيث بلغت معاده كرونباخ (0.73). أمـا ثبـات المقياس في الدراسـات الأخرى؛ فقد تراوحت معـاملات ثبـات الاتسـاق الـاخلي مـا بـين (0.73-0.95) فـي الدراسـات الآتيـة (Rosenberg, 1979) Bracey, ) (Lee, 2003) (Robins, Hendin, \&Trzesniewski, 2001) (Ying, Lee, \& Tsai, 2004) (Bamaca, \&Umana-Taylor, 2004 (Martin-Albo, Navarro, \&Grijalvo, 2007) كما تم حساب ثبات المقياس عن طريق إعادة تطبيق المقياس فتر اوح ما بين (0.84-0.90) في الدراسـات الآتية Ying, Lee, \& Tsai, ) (Rosenberg, 1979) (Silber,\&Tippett1965) (2004) (Martin-Albo, Navarro, \&Grijalvo, 2007) الواردة في منصور

أمـا في البيئة العربيـة فقد بلـغ معامـل الثبـات (0.93) (0.86) (0.84)، بطريقـة التجزئسة النصفية في دراسـات (الردعـان، والصـويلح، 2014) (منصـور، 2012) (عـاء الدين، 2010) على التوالي، أمـا معامل الثبـات بطريقة الاتسـاق الـاخلي باستخدام كرونباخ ألفا فقد بلغ (0.79) (0.78) (0.88) (0.74) (0.73) (0.86) 
في در اسـات (منصـور ، 2012) (الحر احشـة، 2012) (عـلاء الدين، 2010) (أبو غزال، وجر ادات، 2009) (جر ادات، 2006) (سلامة، 1991) على التى التوالي، أمـا معامل الثبات باستخدام الإعادة باستخدام معادلة بيرسون فقد بلغ (2010) (0.61) (0.79) في

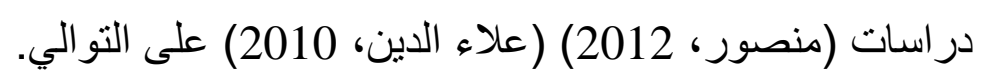

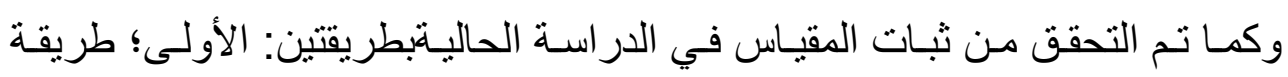

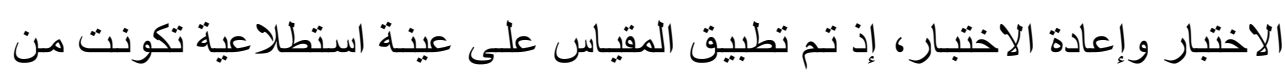
(30) طالبة من مجتمع الدر اسة ذاته، وبفارق زمني (14) يوماً بين مرتي التطبيق،

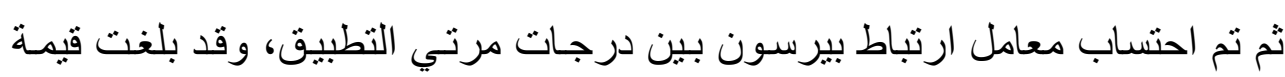

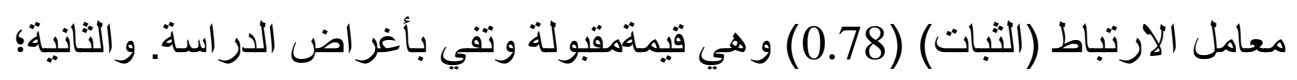

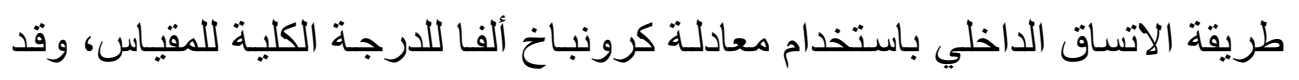
بلغت قيمة معامل الثبات لمستوى تقدير الذات لدى الطالبات (0.82) للارجة الكلية، وهي تعد معاملات مقبولة وتفي بأغر اض الدر اسة.

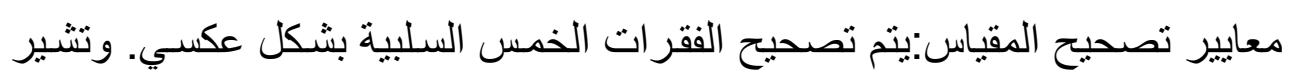

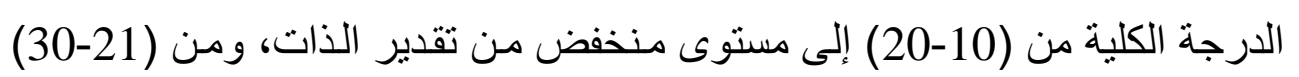
إلى مستوى متوسط، ومن (31-30) إلى مستوى مرتفع من تقدير الذات.

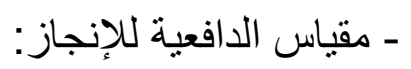
وصف المقياس: لتحقيق أهداف الدراسـة تم استخدام المقيساس الذي طوره العزام (2013) لقياس دافعية الإنجاز ، والذي يتكون من (54) فقرة، موز عة على (5) أبعاد

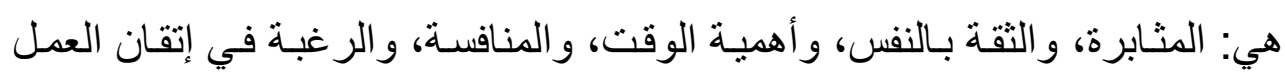

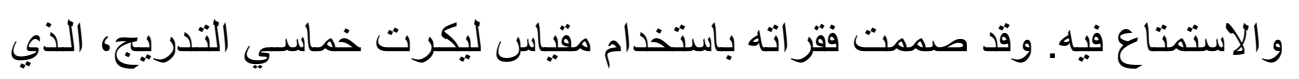

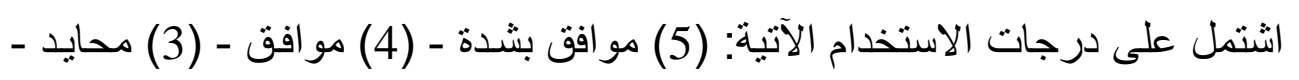

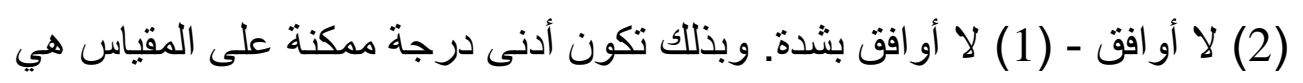

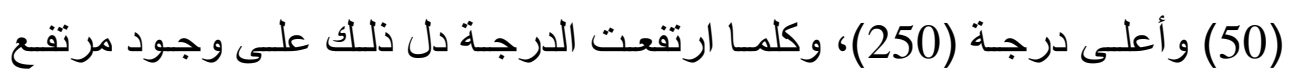

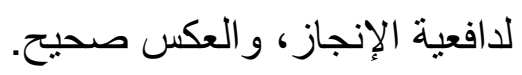


صـق المقيـاس: وقد تم التحقق مـن صـدق المحتوى؛ بعرضــه على مجمو عـة مـن المحكمين، وأخذ ملاحظاتهم وتعديلاتهم بعين الاعتبار ، وكذللك تم التأكد من صدق البناء؛ بتطبيقه على عينة استطلاعية، حيث تم استبعاد (4) فقرات من أصل (58) فقرة، ليصبح المقياس بصورته النهائية مكوناً من (54) فقرة. أما في الدر اسة الحالية؛ فقد ثم التحقق من صدق المحتوى للمقياس بعرضه على (5) محكمين من ذوي الاختصـاص في علم النفس التربوي، حيث طلب منهم الاطلاع على المقياس وإبداء الملاحظات حوله، من حيث مناسبة الفقرات للفئة المستهدفة و انتمائهـا للأبعـاد، ووضـوح المعنىى، وأيـة ملاحظـات أخـرى مناسبة، وتم الأخـذ بالملاحظات الواردة التي تمثلت بإعادة الصياغة، وتعديل بعض الفقرات، وحذف (4) فقر ات لعـدم ملاعمتهـا. وتكـون المقيـاس بصـورته النهائيـة مـن قسـين: الأول خـاص بجمـع معلومـات ذاتيـة عـن أفر اد عينـة الدر اسـة تتمثنل في جنس الطالب، و الصف الدر اسـي، والثاني يشتمل على (50) فقرة موزعـة بالتسـاوي على الأبعاد الأصلية للمقياس. ثبات المقياس:تم التحقق من ثبات المقياس بطريقة الاتساق الداخلي باستخدام معادلة كرونبـاخ ألفـا؛ وقـــ تر اوحـت معـاملات الثبـات للأبعـاد الفرعيـة (0.74-0.83)، وللمقيـاس ككـل (0.91)، ومعامـل ثبـات الإعـادة (الاسـتقرار) باسـتخدام معادلـة بيرسون؛ وقد تر اوحت معاملات الثبات للأبعـاد الفرعية (0.78-0.84)، وللمقياس ككل (0.82)، وتعتبر هذه القيم جيدة ومناسبة لأغر اض الدر اسة. أمـا في الدراسـة الحاليـة؛ وللتحقق مـن ثبـات المقبـاس تم اسـتخدام طريقـة الاختبـار و إعادة الاختبار ، إذ تم تطبيق المقياس على عينة استطلاعيةتكونت من (30) طالبة مـن مجتمـع الدر اسـة ذاتـه، وبفـارق زمنـي (14) يومـاً بـين مرتـي التطبيـق، ثم تـم احتسـاب معامل ارتبـاط بيرسون بين درجـات مرتي التطبيق، وتر اوحت قيمهـ بين (0.93-0.88)، كما بلغت للدرجة الكلية (0.97)، و هي قيم مرتفعة من الثبات. كمـا تم التحقق أيضاً من ثبات المقياس بطريقة الاتساق الداخلي باستخدام معادلة كرونباخ 
ألفا، وقد تر اوحت قيم معـاملات الثبـات للأبعـاد الفرعيـة لمسـتوى الدافعيـة للإنجـاز للأبعـاد بـين (0.92-0.92)، و(0.98) للارجـة الكليـة، وهـي تعـد معـاملات ثبـات مرتفعة، وجدول (2) يوضح قيم معامل الثبات المحسوبة بطريقة الإعـادة، وطريقة الاتساق الداخلي لمقياس الدافعية للإنجاز . جدول (2) قيم معامل الثبات لمقياس الدافعية للإنجاز ككل و الأبعاد الفرعية المكونة لمقياس الدافعية للإنجاز

\begin{tabular}{|c|c|c|}
\hline معامل الآساق الإخلي & معامل الإعادة & الأبعاد \\
\hline 0.94 & 0.89 & المثابرة. \\
\hline 0.92 & 0.91 & الثقة بالنفس. \\
\hline 0.94 & 0.89 & أهمية الوقت. \\
\hline 0.92 & 0.88 & المنافسة. \\
\hline 0.95 & 0.93 & الرغبة في إتقان العمل والاستمتاع فيه \\
\hline 0.98 & 0.97 & الكلي \\
\hline
\end{tabular}

معايير تصحيح المقياس:لقد اعتمد المعيار التالي للحكم على استجابات الطالبات على الأداة (1- أقل من 1.5) بدرجـة متدنيـة جداً، و(1.5- أقل من 2.5)بدرجـة متدنيـة، و(2.5- أقل من 3.5)بدرجة منوسطة، و(3.5- أقل من 4.5) بدرجة عالية، و(4.55) بدرجة عالية جداً، و(3.43-5) بدرجة كبيرة، كما في المقياس الأصلي. إجراعات الار اسةة:

تم تخصيص إحدى الثعبتين من مساق علم النفس التربوي التي بدرسـها الباحث في الفصل الأول من العام الدر اسي الجامعي (2017/2016)، وبعد ذلك؛ حددت إحدى المجمو عتين بالمجموعـة التجريبيـة وكان عدد الطالبـات فيهـا (40) طالبـة، وكانت الأخرى ضابطة وبلغ عدد الطالبات فيها (35) طالبة. ثم وزع المقياسين قبل تطبيق البرنامج في كلتا المجمو عتين (الاختبار القبلي)، ثم تم تطبيق البرنامج التدريبي على الطالبات في المجموعة التجريبية حيث استغرقت مدة التطبيق (12) أسبوع تقريباً بو اقع محاضرتين/ جلستين أسبو عياً، وبعد الانتهاء من تطبيق البرنامج، تم تطبيق المقاييس مـرة أخرى (الاختبـار البعدي)، ليصـار إلى تحليلها و التعامل مـع بياناتها 
إحصـائياً وذلك باستخدام الرزم الإحصـائية (SPSS) الحاسوبية للكثف عن أثر

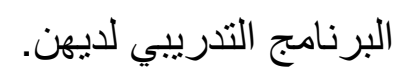
المعالجة الإحصائية:عولجت البيانات بعد ترميز هـا باستخدام الحاسوب، واستخدمت

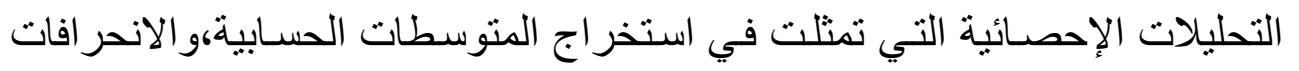

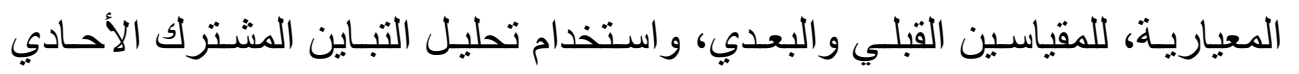

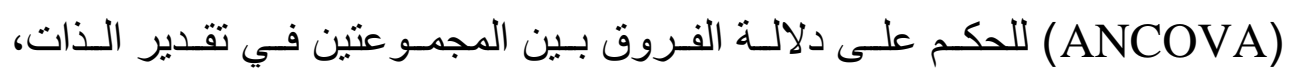
و استخدام تحليل التباين المشترك المتعدد (MNCOVA) للحكم على دلالة الفروق بين المجمو عتين في أبعاد مقياس الدافعية للإنجاز . النتائج: لاختبار صحة الفرض لأول والذي ينص على:توجد فروق ذات دلالة إحصائية عند مستوى الالالة (0.05=a) بينالمجموعة التجريبية والمجموعة الضـابطة فيتقدير

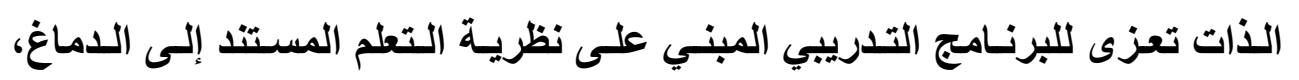

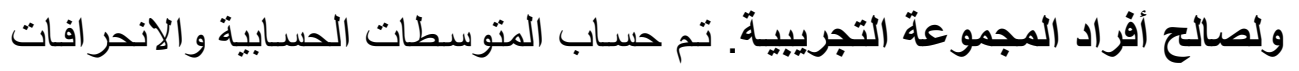
المعيارية لاستجابات الطالبات على مقياس تقدير الذات في المجمو عتين التجريبية و الضابطة، كما تم استخدام تحليل التباين المشترك (ANCOVA) للحكم على دلالية الفروق بين المجمو عتين التجريبية (التي تعرضت للبرنـامج التدريبي) و الضـابطة

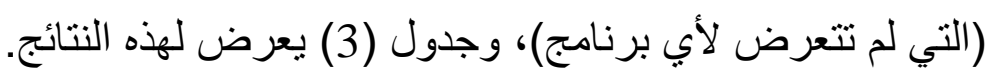


جدول (3) المتوسطات الحسابية والانحر افات المعيارية لاستجابات طالبات المجموعة التجريبية و المجمو عة الضابطة على مقياس تقدير الذات في القياسين

$$
\text { القبلي و البعدي }
$$

\begin{tabular}{|c|c|c|c|c|c|}
\hline \multicolumn{2}{|c|}{ تقدير الذات (بعدي) } & \multicolumn{3}{|c|}{ تقدير الذات (قبلي) } & \multirow[b]{2}{*}{ المجموعة } \\
\hline الانحراف المعياري & الحستابي & الاتحراف المعياري & الحستبي & العدد & \\
\hline 3.71 & 39.00 & 6.48 & 31.25 & 40 & التجريبية \\
\hline 4.37 & 35.91 & 5.96 & 32.46 & 35 & الضابطة \\
\hline 4.29 & 37.56 & 6.23 & 31.81 & 75 & الكلي \\
\hline
\end{tabular}

يتضح من جدول (3)وجود فروق بين المجمو عتين التجريبية و الضـابطة في القياسين القبلي و البعدي؛ ولمعرفـة فيمـا إذا كانــ الفـروق دالـة إحصـائياً بـين المجـو عتين التجريبية و الضابطة، تم إجر اء تحليل التباين المشترك، وجدول (4) بعرض لهذه النتائج.

جدول (4) نتائج تحليل التباين المشترك لدلالة الفروق بين المجموعتين التجريبية و الضابطة في تقدير الذات

\begin{tabular}{|c|c|c|c|c|c|}
\hline مستوى الدلالة & ف & متوسط المربعات & درجات الحرية & مجموع المربعات & التباين \\
\hline 0.488 & 0.49 & 7.94 & 1 & 7.94 & التقدير قبلي \\
\hline \multirow{3}{*}{0.001} & 11.20 & 183.41 & 1 & 183.41 & المجموعة \\
\hline & & 16.37 & 72 & 1178.80 & الخطأ \\
\hline & & & 74 & 1364.48 & الكلي \\
\hline
\end{tabular}

يتضح من جدول (4)وجود فروق دالة إحصـائياً بين المجموعتين التجريبية (التي تعرضت للبرنامج التدريبي)، و الضـابطة (التي لـم تتلق أي برنـامج تدريبي)، حيث كانت قيمة ف (11.20)، و هي دالة إحصائياً عند مستوى الدلالة (a=a.05)، لذا تم رفض الفرضية الصفرية وقبول الفرضية البديلة، وقد كانت الفروق لصـالح طالبات المجمو عة التجريبية. كما يتضح من المتوسطات الحسابية المعدلة في جدول (5) فقد كان المتوسط الحسابي المعدل للمجموعة التجريبية (39.03) وللمجموعة الضـابطة (35.88)، مما يدل على أن البرنـامج التدريبي سـاهم في تحسين تقدير الذات لدى طالبات المجمو عة التجريبية. 
جدول (5) المتوسطات الحسابية المعدلة لتقدير الذات في المجموعنين التجريبية و الضنابطة

\begin{tabular}{|c|c|c|}
\hline الخطأ المعياري & المتوسط الحسابي & المجموعة \\
\hline 0.64 & 39.03 & التجرييية \\
\hline 0.69 & 35.88 & الضابطة \\
\hline 0.47 & 37.46 & الكلى \\
\hline
\end{tabular}

لاختبار صحة الفرض الثاني والأي ينص على:توجد فروق ذات دلالة إحصائية عند مسـتوى الدلالـة (0.05=a) بينالمجموعـة التجريبيـة والمجموعـة الضـابطة في الدافعيـة للإنجاز تعزى للبرنـامج التدريبي المبنـي على نظريـة التعلم المستند إلى الـــماغ، ولصـالح أفـراد المجموعـة التجريبيـة. تـم حسـاب المتوســات الحسـابية و الانحر افات المعياريـة لاستجابات طالبات المجمو عتين التجريبية و الضـابطة على مقياس الدافعية للإنجاز في القياسين القبلي و البعدي، كمـا تم استخدام تحليل التباين المشترك متعدد المتغيرات التابعة (MANCOVA) للحكم على دلالة الفروق بين المجمو عتين التجريبية (التي خضعت للبرنامج التدريبي) و المجمو عة الضابطة (التي لم تتعرض لأي برنامج)، وجدول (6) يعرض لهذه النتائج. جدول (6) المتوسطات الحسابية و الانحر افات المعيارية لاستجابات طالبات المجموعتين التجريبية والضابطة على مقياس الدافعية للإنجاز

\begin{tabular}{|c|c|c|c|c|c|c|c|c|c|c|c|c|}
\hline \multicolumn{2}{|c|}{ 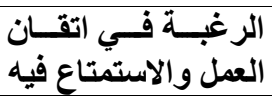 } & \multicolumn{2}{|c|}{ المنافسة } & \multicolumn{2}{|c|}{ أهمية الوقت } & \multicolumn{2}{|c|}{ الثقة بالنفس } & \multicolumn{3}{|c|}{ المثابرة } & \multirow[b]{2}{*}{ المجموعة } & \multirow[b]{2}{*}{ القياس } \\
\hline فلـــــــرا & الحسابي & المعياري & الحستوسي & فالانحـــرا & الحستبي & الالتحياري & الحسابي & فالمعياري & الحستوسي & العدد & & \\
\hline 11.26 & 36.05 & 10.28 & 33.28 & 9.73 & 34.40 & 10.52 & 33.35 & 11.18 & 35.83 & 40 & التجريبية & \multirow{3}{*}{ القبلي } \\
\hline 10.53 & 37.23 & 7.31 & 36.09 & 9.48 & 35.43 & 7.40 & 35.69 & 8.54 & 36.71 & 35 & الضابطة & \\
\hline 10.87 & 36.60 & 9.07 & 34.59 & 9.57 & 34.88 & 9.21 & 34.44 & 9.98 & 36.24 & 75 & الكلي & \\
\hline 2.88 & 46.70 & 2.70 & 45.65 & 3.32 & 44.78 & 3.51 & 44.43 & 3.32 & 45.65 & 40 & التجريبية & \multirow{3}{*}{ البعدي } \\
\hline 3.38 & 42.94 & 5.40 & 40.03 & 3.59 & 42.09 & 3.77 & 40.66 & 4.88 & 41.49 & 35 & الضابطة & \\
\hline 3.63 & 44.95 & 5.02 & 43.03 & 3.68 & 43.52 & 4.08 & 42.67 & 4.60 & 43.71 & 75 & الكلي & \\
\hline
\end{tabular}

يتضح من جدول (6) وجود فروق في القياسين القبلي و البعدي بين المجموعتين التجريبية و الضابطة في مجالات مقياس الدافعية للإنجاز ، ولمعرفة فيما إذا كانت هذه 
الفروق بين المجمو عتبـن دالة إحصـائياً؛ تـم إجراء تحليل التبـاين المشـترك متعدد المتغير ات التابعة (MANCOVA)، وجدول (7) يعرض لهذه النتائج. جدول (7) نتائج تحليل التباين المشترك متعدد المتغير ات التابعة (MANCOVA) لدلالة الفروق بين المجموعتين التجريبية والضابطة في الدافعية للإنجاز

\begin{tabular}{|c|c|c|c|c|}
\hline مستوى الدلالة & درجات الحرية للخطأ & درجات الحرية الافتراضية & ف ف & هوتلنج تريس \\
\hline 0.000 & 64.00 & 5.00 & 6.68 & 0.52 \\
\hline
\end{tabular}

للبرنامج التدريبي) و الضابطة (التي لم تتلق أي برنامج) في الدافعيـة للإنجـاز تعزى لمتغير المجموعـة، حيث كانت قيمـة هوتلنج تريس (0.052)، وقيمـة ف (6.68)، و هي دالة إحصائياً عند مستوى الدلالة (a=0.05)، لذا تم رفض الفرضية الصفرية وقبول الفرضية البديلة. ولمعرفة المجالات التي كانت فيها الفروق بين المجمو عتين دالة إحصائياً، تم إجراء تحليل التباين المشترك لكل مجال من مجالات مقياس الدافعية للإنجاز، وجدول (8) يعرض لهذه النتائج. 
جدول (8) نتائج تحليل التباين المشترك لدلالة الفروق في المجالات الفرعية لمقياس

الدافعية للإنجاز بين المجمو عة التجريبية و المجمو عة الضابطة

\begin{tabular}{|c|c|c|c|c|c|c|}
\hline مسلالة الدتوى & ف & متوبعـــــ المربعات & الدرجية & المربعات & المجال & التباين مصـــــر \\
\hline 0.587 & 0.30 & 4.99 & 1 & 4.99 & المثابرة & \multirow{5}{*}{ القبلي } \\
\hline 0.302 & 1.08 & 14.10 & 1 & 14.10 & الثقة بالنفس & \\
\hline 0.258 & 1.30 & 16.21 & 1 & 16.21 & أهمية الوقت & \\
\hline 0.192 & 1.73 & 31.54 & 1 & 31.54 & المنافسة & \\
\hline 0.071 & 3.38 & 32.69 & 1 & 32.69 & والاستبمتاع في اتقان العمل & \\
\hline 0.000 & 14.45 & 242.15 & 1 & 242.15 & المثابرة & \multirow{5}{*}{ المجموعة } \\
\hline 0.000 & 16.31 & 212.41 & 1 & 212.41 & الثقة بالنفس & \\
\hline 0.003 & 9.60 & 119.52 & 1 & 119.52 & أهمية الوقت & \\
\hline 0.000 & 26.49 & 482.04 & 1 & 482.04 & المنافسة & \\
\hline \multirow[t]{11}{*}{0.000} & 22.51 & 218.03 & 1 & 218.03 & والاستبتة في فيقان العمل & \\
\hline & & 16.76 & 68 & 1139.64 & المثابرة & \multirow{5}{*}{ الخطأ } \\
\hline & & 13.02 & 68 & 885.59 & الثقة بالنفس & \\
\hline & & 12.44 & 68 & 846.21 & أهمية الوقت & \\
\hline & & 18.20 & 68 & 1237.28 & المنافسة & \\
\hline & & 9.68 & 68 & 658.50 & والاستمتاع في اتقان العمل & \\
\hline & & & 74 & 1563.55 & المثابرة & \multirow{5}{*}{ الكلي } \\
\hline & & & 74 & 1230.67 & الثقة بالنفس & \\
\hline & & & 74 & 1002.72 & أهمية الوقت & \\
\hline & & & 74 & 1867.95 & المنافسة & \\
\hline & & & 74 & 973.79 & والاستبتّاع فيه اتقان العمل & \\
\hline
\end{tabular}

يتضـح مـن جـدول (8) وجـود فـروق دالـة إحصــائياً بـين المجمـوعتين التجريبيـة و الضابطة في جميع المجالات الفر عية لمقياس الدافعية للإنجاز ، وهي: ــ المثابرة، حيث كانت قيمـة ف (14.45)، وهي دالـة إحصـائياً عند مستوى الدلالة (0.05=a)، ولقد كانت هذه الفروق لصالح المجموعة التجريبية، حيث بلغ المتوسط 
الحسابي المعدل للمجموعة التجريبية (45.46)، بينما بلغ المتوسط الحسابي المعدل لللجمو عة الضابطة (41.70)، كما يتضح من جدول (9).

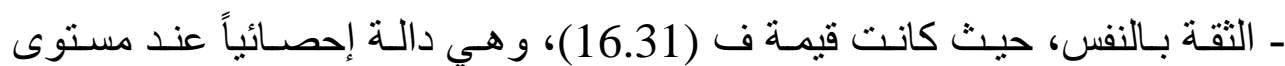

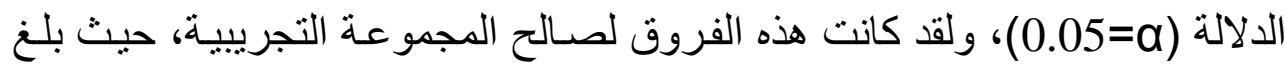
الهتوسط الحسابي المعدل للمجموعة التجرييية (44.31)، بينما بلغ المتوسط الحسابي المعدل للمجموعة الضابطة (40.79)، كما يتضح من جدول (9). ـ أهمية الوقت، حيث كانت قيمة ف (9.60)، وهي دالة إحصائياً عند مستوى الدلالة (0.05=a)، ولقد كانت هذه الفروق لصالح المجموعة التجريبية، حيث بلغ المنوسط الحسابي المعدل للمجموعة التجريبية (0.75.0د)، بينما بلغ المنوسط الحسابي المعدل لللجمو عة الضابطة (42.11)، كما يتضح من جدول (9). ــ المنافسة، حيث كانت قيمة ف (26.49)، وهي دالة إحصائياً عند مستوى الدلالة. (0.05=a)، ولقد كانت هذه الفروق لصالح المجموعة التجريية، حيث بلغ المتوسط الحسابي المعدل للمجموعة التجريبية (45.50)، بينما بلغ المتوسط الحسابي المعدل لللجمو عة الضابطة (40.20)، كما يتضح من جدول (9).

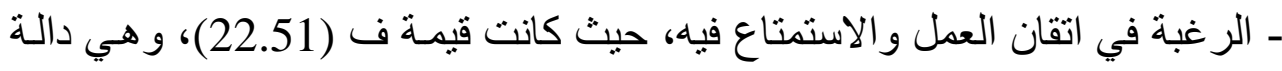

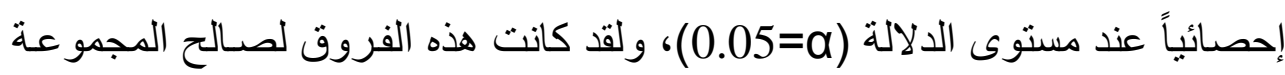
التجرييية، حيث بلغ المتوسط الحسابي المعدل للمجموعة التجرييية (0.61) (46.61)، بينما بلغ المتوسط الحسابي المعدل للمجموعة الضابطة (43.04)، كمـا يتضح من جدول

وتندل النتائج السابقة على أن البرنامجالتدريبي قد ساهم في رفع الدافعية للإنجاز لاى

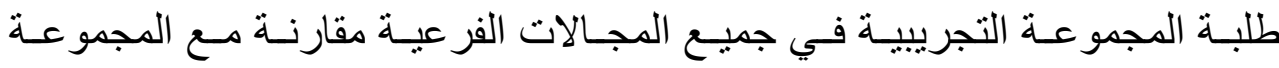
الضابطة. 
جدول (9) المتوسطات الحسابية المعدلة والأخطاء المعيارية لاستجابة طالبات

المجمو عتين التجريبية و الضابطة على مقياس الدافعية للإنجاز

\begin{tabular}{|c|c|c|c|}
\hline الخطأ المعياري & المتوسط الحسابي & المجموعة & المجال \\
\hline 0.66 & 45.46 & التجريبية & المثابرة \\
\hline 0.71 & 41.70 & الضابطة & \\
\hline 0.58 & 44.31 & التجريبية & الثقة بالنفس \\
\hline 0.62 & 40.79 & الضابطة & \\
\hline 0.57 & 44.75 & التجريبية & أهمية الوقت \\
\hline 0.61 & 42.11 & الضابطة & \\
\hline 0.69 & 45.50 & التجريبية & المنافسة \\
\hline 0.74 & 40.20 & الضابطة & \\
\hline 0.50 & 46.61 & التجريبية & الرغبة في اتقان العمل والاستمتاع \\
\hline 0.54 & 43.04 & الضابطة & \\
\hline
\end{tabular}

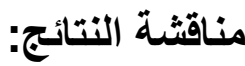

أثــارت نتـائج الدر اســة إلى أن البرنـامج التـدريبي سـاهم في تحسـين تقدير الـذات والدافعية للإنجاز لدى طالبات المجمو عة التجريبية. ويمكن تفسير هذه النتيجـة على أساس أن الجلسات التدريبية التي تم بناؤها في ضوء مبادئ نظرية التعلم المستند إلى الدماغ، زادت مـن الإثـارة و الدافعيـة والانتبـاه و التشـويق والمتعـة، لمـا تضــنته مـن أنشطة وتدريبات و أدوات تقييم متنو عة، مما انعكس إيجاباً على مفهومي تقدير الذات و الدافعيـة للإنجـاز، لا سيما أن اسـتخدام هذا البرنـامج يعتبر خـروج عـن الطريقـة التقليدية في تنـاول موضـوعات محددة من مسـاق علم النفس التربوي، وهي نتيجة تؤكد التر ابط بين تقدير الذات والدافعيـة للإنجاز . ومن جهة أخرى؛ فإن البرنـامج التدريبي عمل على توفير المنـاخ أو الظروف الفيزيقية و الفسيولوجية المناسبة في ضــوء مبـادئ عمـل الـدماغ، وكذللك البيئة البصــرية الجذابـة، واسـتخدام الألـوان،

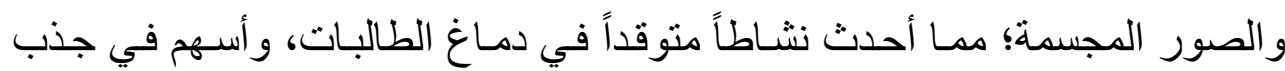
انتباههن وجعل التعلم أكثر متعة. وحيث أن التعلم المستند إلى الدماغ يركز على كيفية التعامل مع سيكولوجية المتعلم وفق خصائصه الدماغية؛ فإن محتوى البرنـامج 
التدريبي المستند إلى الدماغ تم إعداده في ضوء خصـائص البيئة المحيطة بـالمتعلم، ليجد المتعلم معنى للخبرات التعليمية المكنسبة، وبالتالي يستطيع دمـج هذه الخبرات في بنيته المعرفية. وجدير بالذكر أن البرنـامج التدريبي في هذه الدراسـة اشتمل على (5) مر احل في تطبيقه هي؛ مرحلة الإعداد، ومرحلة الاكتساب، ومرحلة الإيضـاح، ومرحلة تكوين الذاكرة، وأخيراً مرحلة التكامل الوظيفي؛ وهذه المر احل استندت إلى مر احل التعلم حسب نظرية التعلم المستند إلى الدماغ. وتضمنت استر اتيجيات تتفيذ البرنامج؛ العمل ضمن مجمو عات، و التعلم من خلال اللعب، و التعلم من خلال المشرو عات، واستخدام الإنترنـت و غير هـا، ممـا سـاهم في تحسـين تقدير الذات لـدى الطالبـات و الدافعيـة

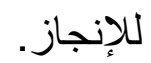
وتتفق هذه النتيجة مع ما توصلت إليه نتائج دراسـات: الخو الدة، وقطاوي (2015)، و السواط (2015)، و الطيطي، ورواثـدة (2013)، و عبد الجواد (2013)، و أحمد Aziz-Ur-(2013)، وبدر (2013)، والخليفة (2013)، وعزيز الرحمن وزملائه (Dehman, et al, 2012 وأوزدين، وجـولتكن (Ozden, \& Gultekin, 2008)، ودومـان ( Duman, . $(2006$ 


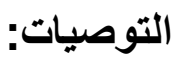

في ضوء النتائج التي تم التوصل إليها؛ يقدم الباحث مجمو عة التوصيات الآتية: ـ اعتماد البرنامج التدريبي المعد في هذه الدر اسة سواء أكان ذلك لطلبة الجامعات، أو لتأهيل المعلمين قبل الخدمة أو في أثناء خدمتهم الفعلية. ـ إجر اء مزيد من الدر اسات تتناول مفهوم التعلم المستند إلى الدماغ لما لهذا المفهوم من معان متعددة و مضامين متنو عة. - ربط موضـوع التعلم المستند إلى الدماغ بسـائر العمليـات المعرفيـة العليـا (أنواع التفكير) الأخرى مثل التفكير الناقد، والتفكير الإبداعي، والتفكير التأملي، وتفكير مـا ور اء المعرفة.

- إنثـاء حاضـنات ومر اكز تدريبيـة في الجامعـات الأردنيـة تقوم على تطبيق هذا البرنامج و غيره من البر امج المبنية على التعلم المستند إلى الدماغ لكل مهتم. - توسيع شريحة المستفيدين من هذا البرنامج وتكييفه ليناسب مر احل عمريـة مبكرة ليتم التدريب على التعلم المستند إلى الدماغ ويصبح جزءاً من ذات الفرد. ـ الاهتمام ببيئة التعلم في ضوء ما تسفر عنه نتائج البحث المتعلق بالتعلم المستند إلى الدماغ. - إثر اء خطط المساقات الجامعية بالأنشطة والمتطلبات التي تساعد على تنشيط عمل الدماغ و الاستفادة من طاقاته الكامنة. ـ الاهتمام بتنمية تقدير الذات لدى طلبة المر احل الدر اسية المختلفة. ـ الاهتمام بزيادة الدافعية للإنجاز لدى طلبة المر احل الدر اسية المختلفة. 


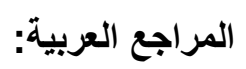

ـ أبو حطب، فؤاد عبد اللطيف، وصادق، آمال أحمد مختار (2009). علم النفس التربوي (ط6). القاهرة: مكتبة الأنجلو المصرية. - أبو رياش، حسين محمد (2007). التعلم المعرفي. عمان: دار المسيرة.

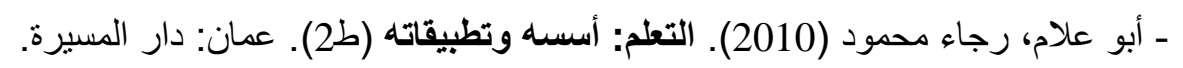
ـ أبو غزال، معاوية، وجر ادات، عبد الكريم (2009). أنماط تعلق الر اشدين و علاقتها بتقدير الذات و الشعور بالوحدة، المجلة الأردنية في العلوم التربوية، 5(1)، 45-57.

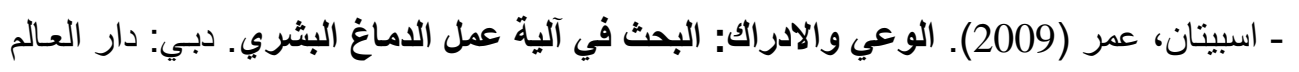
العربي، ومؤسسة محمد بن ر اشد آل مكتوم.

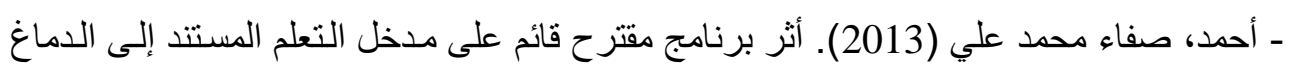
في تصحيح التصور ات البديلة وتنميـة عمليات العلم والدافعيـة للإنجاز للى تلاميذ الصف لـف الأول المتوسط. مجلة دراسات عربية في التربية وعلم النفس، 33(2)، 48-98.

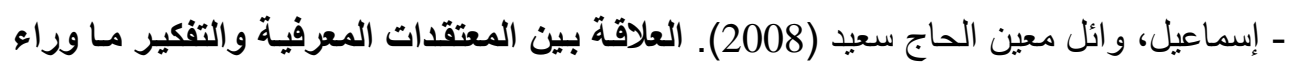

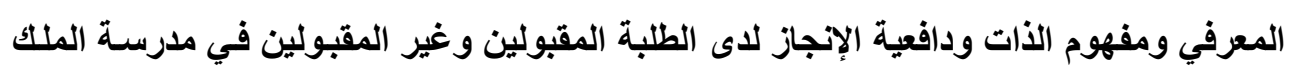

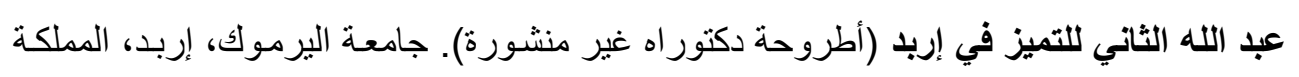
الأردنية الهاشمية. ـ أندرسون، جون ر. (2016). علم النفس المعرفي وتطبيقاتهـ. (مفيد نجيب حواثين، وفاضل محمود خشاوي، ومحمد صبري سليط: مترجمون). عمان: دار الفكر. ـ أندرمان، إيريك م.، وأندرمان، لينلي هيكس (2016). دافيـة الغرفـة الصفية. (أحسلام البـاز حسن: مترجم). عمان: دار الفكر. - إيجلمان، ديفيد (2013). المتخفي: الحيوات السرية للادماغ. (حمزة بن قبلان المزيني: مترجم). بيروت: دار جداول. ـ أورمرود، جين إليس (2016). التعلم الإنساني. (فاضل محمود خشاوي، ومفيد نجيب حو اششين، ونبيلة نمر دودين: منرجمون). عمان: دار الفكر.

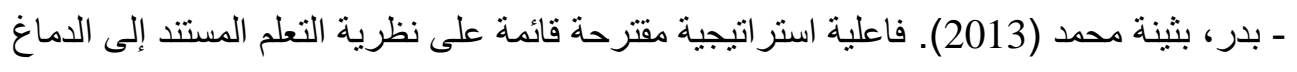
في تنمية مهارات التو اصل الرياضي والدافعيـة للإنجاز الدراسي لدى تلميذات المرحلة الابتدائية بالمملكة العربية السعودية. مجلة تربويات الرياضيات، 16(2)، 13-69. 
ـ البيلي، محمد عبد الله، و العمادي، عبد القادر عبد الله، و الصمادي، أحمد عبد المجيد (2016). علم النفس التربوي وتطبيقاته (ط5). الكويت: مكتبة الفلاح. - تريفل، جيمس (2006). هل نحن بلا نظير؟: عالم يستكشف الذكاء الفريد للعقل البشري. (ليلى سيد موسى سيد عيسى الموسوي: مترجم). الكويت: المجلس الوطني للثقافة والفنون والآداب.

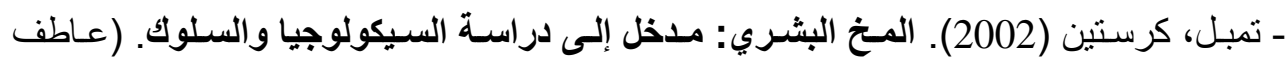

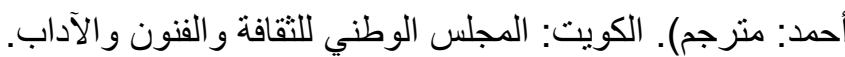
- جاد الحق، نهلة عبد المعطي الصادق(2016). استر اتيجية مقترحة قائمة على التعلم المستند إلى

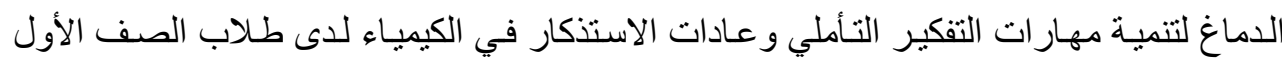
الثانوي. مجلة التربية العلمية، 19(1)، 137-189. - جر ادات، عبد الكريم (2006). العلاقـة بين تقدير الذات والاتجاهـات اللاعقلانيـة لدى الطلبـة الجامعيين، المجلة الأردنية في العلوم التربوية، 2(3)، 143-153. - جلجل، نصرة محمد عبد المجيد (2009). اتجاهـات معاصرة في علم النفس التربوي: بحوث تطبيقية. القاهرة: مكتبة النهضة المصرية. - جنسـ، إيريك (2006). التـريس الفعـال: أكثر مـن 1000 طريقـة عمليـة للتـريس النـاجح. (مكتبة جرير : مترجم). الرياض: مكتبة جرير.

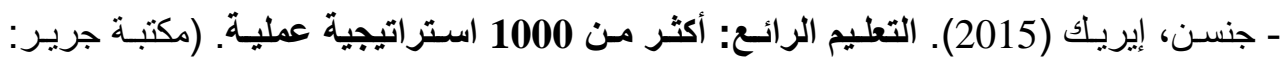
مثرجم). الرياض: مكتبة جرير. - جينسن، إيريك (2007). التعلم المبني على العقل: العلم الجديد للتعليم والتتريب. (مكتبة جرير: مترجم). الرياض: مكتبة جرير. ـ الحارثي، إبر اهيم بن أحمد مسلم (2001). التفكير والتعلم والذاكرة في ضوء أبحاث الدماغ. الرياض: مكتبة الثقري. ـ الحر احشّة، محمد أحمد (2012). تقدير الذات وعلاقتهـه بمستوى التحصيل الأكاديمي: دراسـة مسـحية على الطلبـة الضـباط فـي أكاديميـة العلـوم الثـرطية بإمـارة الثـارقة. مجـــة شــؤون

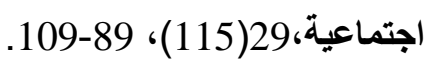
- حسن، نعمة عبد السـلام محمد (2016). القيمـة التنبؤيـة لفاعلية الذات و الدافعيـة للإنجـاز بجودة الحياة لدى طالبات مرحلة الدراسات العليا بكلية التربية، مجلة كلية التربية في العلوم التربويـة، .347-279 (د) (1)40 
- حسنين، خولة يوسف حسن (2011). فاعلية برنامج تعليمي قائم على التعلم المستند إلى الدماغ

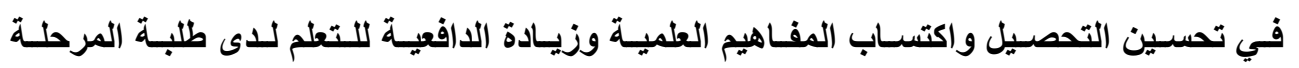
الأساسية في العلوم (أطروحة دكتور اه غير منشورة). الجامعة الأردنية، عمان، المملكة الأردنية الهاشمية. - خليفة، عبد اللطيف محمد (2000). الدافعية للإنجاز. القاهرة: دار غريب.

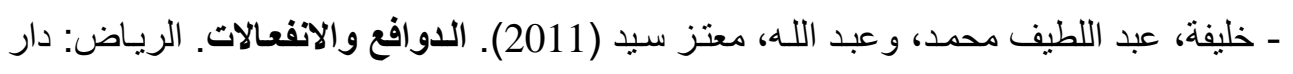
الزهر اء. ـ الخليفة، فاطمة محمد (2013). فعالية برنامج تدريبي قائم على نظرية التعلم المستند إلى الدماغ

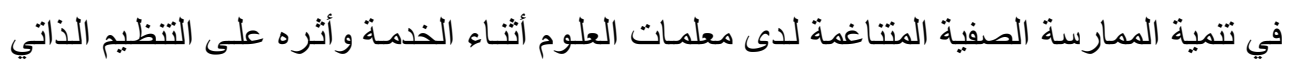

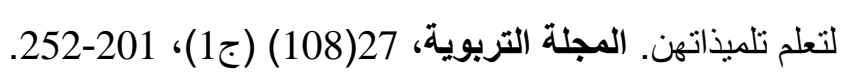
ـ الخو الدة، ماجد خليفة، وقطاوي، محمد إبر اهيم (2015). أثر برنـامج تعليمي قائم على التعلم

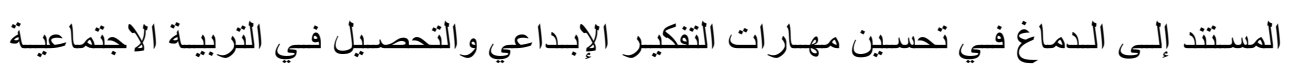

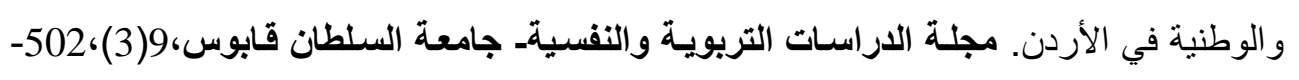

ـ دودين، ثريا يونس، وجروان، فتحي عبد الرحمن (2012). أثر تطبيق برامج التسريع والإثراء

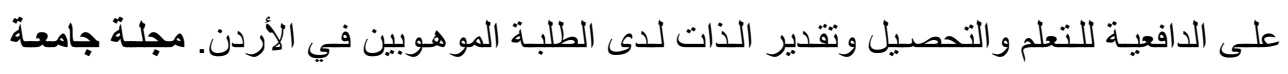
القدس المفتوحة للأبحاث والدراسات، 26(2)، 105-148. ـ الردعان، دلال، و الصويلح، بدر (2014). تقدير الذات و علاقته بالتحصبل الأكاديمي للى عينة

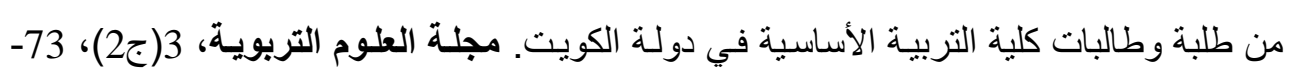

ـ الرشيدي، بشير صـالح، وأبو علام، رجاء محمود، و الجبر ، زينب علي، و الهاجري، عبد الله جاسم (2004). الموسوعة العلمية للتربية. الكويت: مؤسسة الكويت للتقدم العلمي.

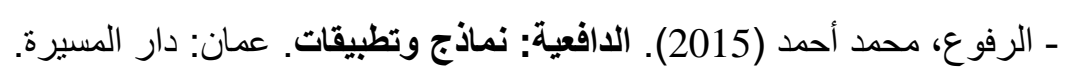

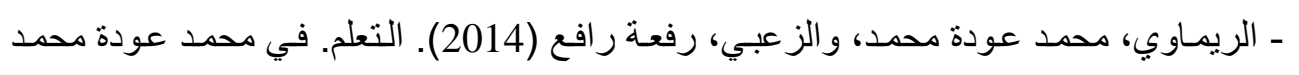
الريماوي (محرر)، علم النفس العام (ط5) (ص: 157-195). عمان: دار المسيرة. ـ الزغول، عماد عبد الرحيم (2006). نظريات التعلم (ط2). عمان: دار الثروق. 
ـ الزيـات، فتحسي مصـفى (1998). الأسسس البيولوجيـة والنفسية للنشـاط العقلـي المعرفي: المعرفة، والذاكرة، والابتكار. القاهرة: دار النشر للجامعات.

ـ الزيات، فتحي مصطفى (2004). سيكولوجية التعلم بين المنظور الارتباطي والمنظور المعرفي (2). القاهرة: دار النشر للجامعات. ـ سالم، هبة الله محمد الحسن، وقمبيل، كبشور كوكو، و الخليفة، عمر هـارون (2012). علاقة

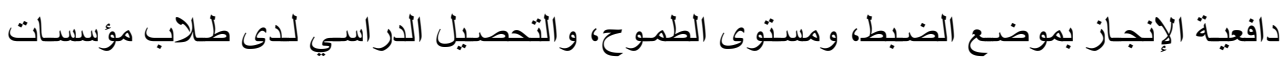

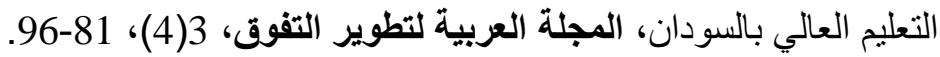
ـ سلامة، ممدوحة محمد (1991). تقدير الذات و الضبط الو الدي للأبناء في نهايـة المر اهقة وبداية الرشد، مجلة دراسات نفسية، 1(4)، 679-702. ـ سليم، مريم داود (2003 أ). تقدير الذات والثقة بـالنفس: دليل المعلمين. بيروت: دار النهضـة العربية.

- سليم، مريم داود (2003 ب). علم نفس التعلم. بيروت: دار النهضة العربية. - سمارة، هنوف، وسمارة، علي، و السلامات، "محمد خير" (2012). درجة تقدير معلمي المرحلة الأساسية الدنيا في المدارس التابعة لمديرية تربية لو اء الرصيفة لذو اتهم و علاقتها بدافعية الإنجاز

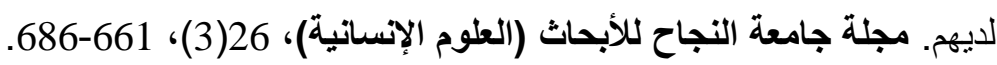
ـ السو اط، وصل الله عبد الله حمدان (2015). فعاليـة برنـامج تدريبي قائم على نظريـة التعلم

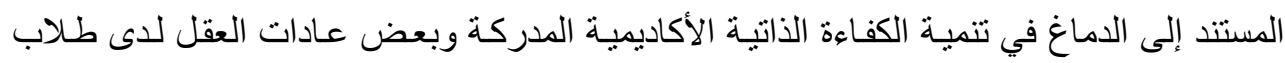
الجامعة. مجلة كلية الآداب- جامعة بنها، 40(3)، 1515-1592.

- سوسـا، ديفيد (2009). العقل البشري وظاهرة التعلم. (خالد العـامري: مترجم). القاهرة: دار الفاروق، ومؤسسة محمد بن راثد آل مكتوم.

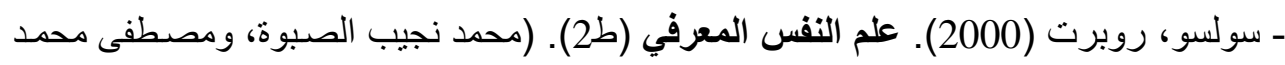
كامل، ومحمد الحسانين الدق: مترجمون). القاهرة: مكتبة الأنجلو المصرية.

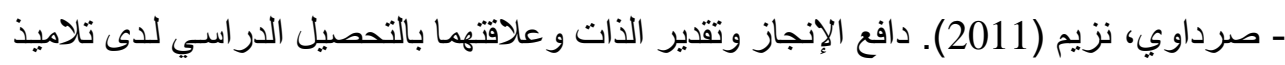
التعليم الثانوي، مجلة دراسات نفسية وتربوية، 6، 300-345. ـ الطيطي، مسلم يوسف، ورواشدة، إبر اهيم فيصل (2013). أثر برنامج تعليمي للتعلم المستند إلى ويل

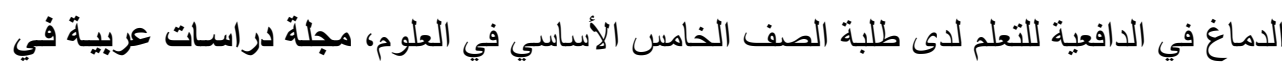
التربية وعلم النفس، 44(3)،12-39. 
- عبد الجو اد، وفاء رشاد راوي (2013). أثر استخدام برنامج قائم على التعلم المستتد إلى الدماغ

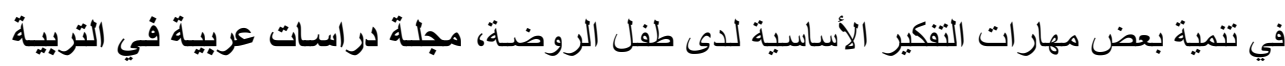
وعلم النفس، 38(4)، 48-76.

ـ عبد الله، مجدي أحمد محمد (2003). علم النفس التربوي بين النظرية والتطبيق. القاهرة: دار المعرفة الجامعية. ـ العتوم، عدنان يوسف، والجراح، عبد الناصر ذياب، و الحموري، فراس أحمد (2017).نظريـات التعلم (ط2). عمان: دار المسيرة.

ــ العتيبي، غزاي حبـاب محمد (2014). فاعليـة الذات وعلاقتهـا بالدافعيـة للإنجـاز للدى طلبـة الصف السادس في محافظة الدوادمي بالمملكة العربية السعودية (رسالة ماجستير غير منشورة). الجامعة الأردنية، عمان، المملكة الأردنية الهاشمية. ــ العز ام، عبد الناصر أحمد (2013). المنـاخ الأسري و علاقته بدافعيـة الإنجاز لدى الطلبـة غير

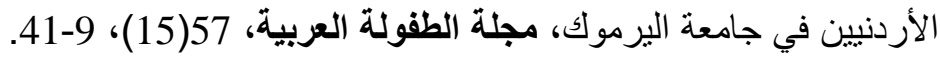
- عسكر، علي، و القنطار ، فايز (2005). مدخل إلى علم النفس التربوي : التربية من منظور نفسي. الكويت: دار الفلاح. ـ علاء الدين، جهاد محمود (2010). هل تنتبأ مستويات تقدير الذات ومصـادر الدعم الاجتمـاعي بالعدوان لدى الطلبة الجامعيين؟، مجلة دراسات (العلوم التربوية)، 37(1)، 50-78.

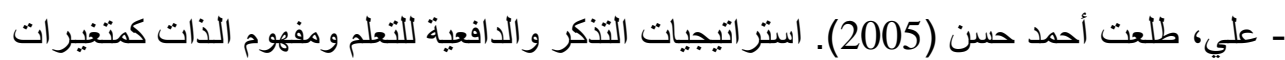
تتبؤيـة للتحصيل الأكاديمي لدى طلاب كليـة التربيـة ببني سويف شـبة الرياضيات، مجلـة كلية التربية بعين شمس، 26(3)، 9-19. - غرينفيلد، سوزان (2017). تغير العقل: كيف تترك التقنيات الرقمية بصماتها على أدمفتـا. (إيهاب عبد الرحيم علي: مثرجم). الكويت: المجلس الوطني للثقافة و الفنون و الآداب. - غرينفيلا، سوزان (2010). رحلة في أسرار العقل (ط2). (شريف الحو اط: منرجم). دمشق: دار الرئ

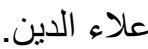
ــ الفحل، نبيل محمد (2000). دراسة تقدير الذات ودافعية الإنجاز لدى طلاب المرحلة الثانوية في كل من مصر و السعودية: دراسة ثقافية، مجلة علم النفس، 14(54)، 6-24. ــ القضاة، محمد فرحان (2014). عادات العقل و علاقتها بدافعية الإنجاز لدى طلاب كلية التربيـة بجامعة الملك سعود، المجلة العربية لتطوير التفوق، 5(8)، 33-59. 
ـ كلارك، باربارا (2013). تنمية الموهبة. (عبير محمد العموري: مترجم). عمان: دار الفكر. ـ لـي بيتري، هربرت، وجوفرن، جون م. (2016). الدافعيـة: النظريـة، البحوث، والتطبيقات.

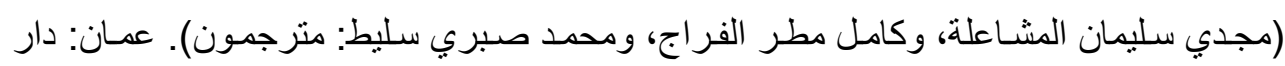
الفكر. - ليندنفيلد، جيل (2005 أ). دستور تقدير الذات. (مكتبة جرير : مترجم). الرياض: مكتبة جرير. ـ ليندنفيلد، جيل (2005 ب). تقدير الذات. (مكتبة جرير : مترجم). الرياض: مكتبة جرير.

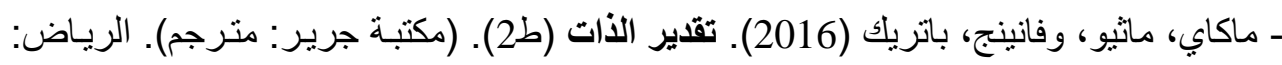
مكتبة جرير. ـ مـالهي، رانجيت سينج، وريزنر، روبرت دبليو. (2006). تعزيز تقدير الذات (ط2). (مكتبة جرير: منرجم). الرياض: مكتبة جرير. ـ محمد، عايدة ذيب عبد الله (2010). الاتتمـاء وتقدير الذات في مرحلة الطفولـة. عمـان: دار الفكر.

ـ محمد، محمد عودة، ومرسي، كمال إبر اهيم (1986). الصحة النفسية في ضوء علم النفس والإسلام (ط2). الكويت: دار القلم. ـ المزروع، ليلى بنت عبد الله (2007). فاعلية الذات و علاقتها بكل من الدافعية للإنجاز و الذكاء

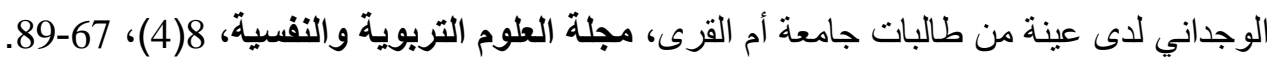
ـ المطوع، محمد حسن (1996). التوازن النفسي لطلاب وطالبـات المرحلتين الإعداديـة و الثانويـة

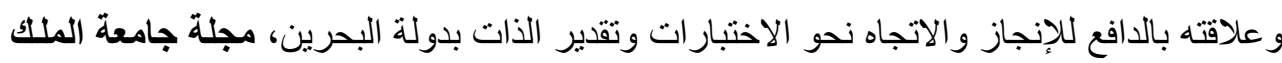

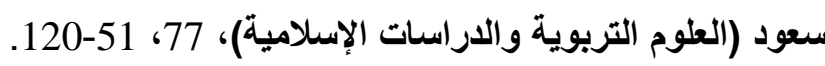

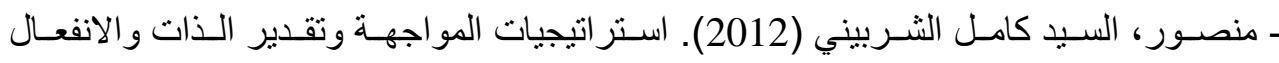
الإيجابي و الانفعال السلبي كمنبئات للكمالية التكيفية. مجلة دراسـات تربويـة ونفسية (مجلة كلية التربية بالزقازيق)، 3(ج2)، 73-97. - مور اي، إدوارد ج. (1988). الدافعية والانفعال. (أحمد عبد العزيز سلامة: مترجم). القاهرة:

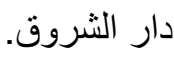
- موسى، رشاد علي عبد العزيز (1994). علم النفس الدافعي: دراسـات وبحوث. القاهرة: دار النهضة العربية. 


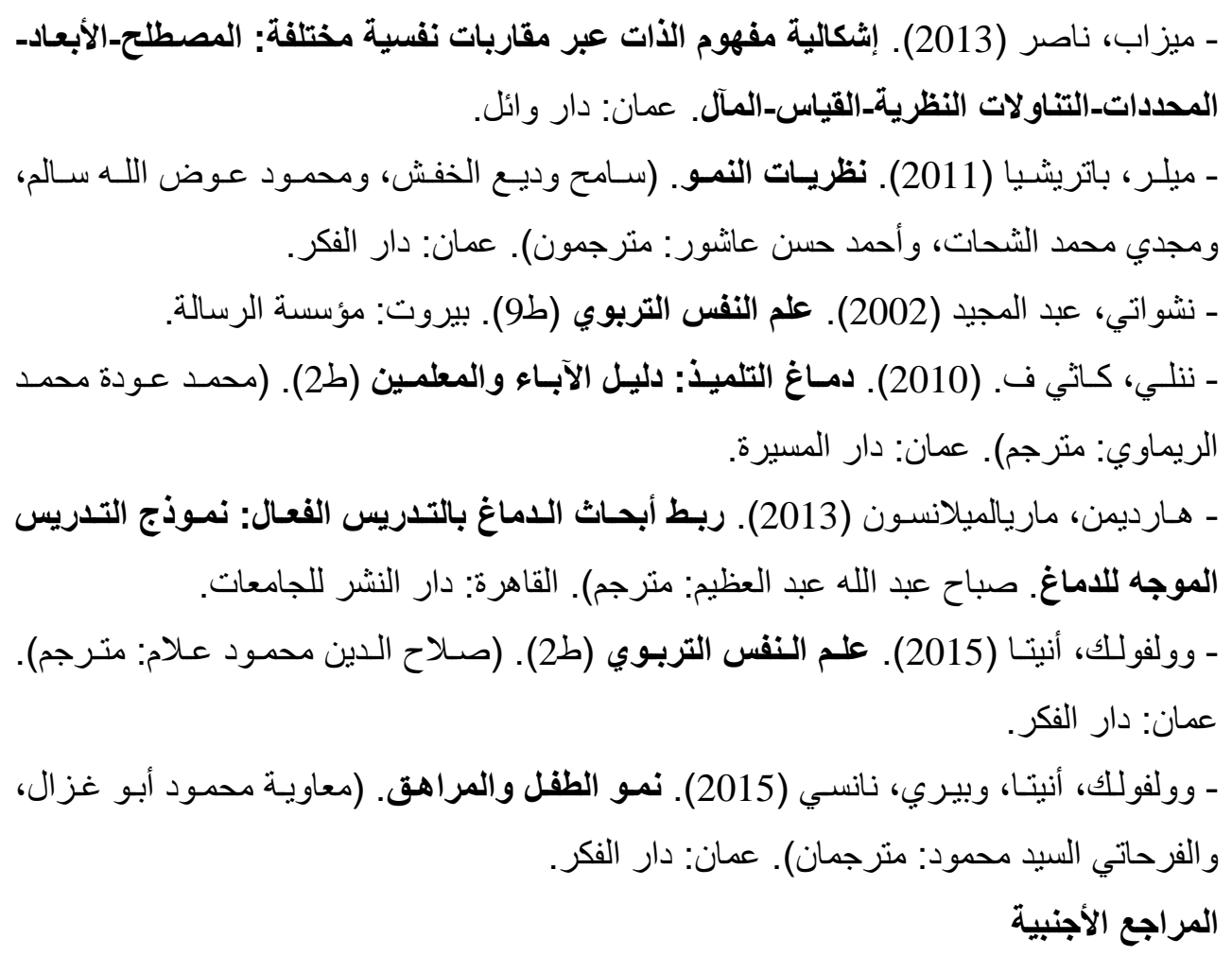

- Aziz-Ur-Rehman, Malik, M. A., Hussain, S., Iqbal, Z., \& Rauf, M. (2012). Effectiveness of brain-based learning theory on secondary level students of urban areas. Journal of Managerial Sciences, 6(1), 113-122.

- Bransford, J. D., Brown, A. L., \& Cocking, R. R. (2000). How people learn: Brain, mind, experience, and school. Washington, D.C: National Academy Press.

- Cercone, K. (2006).Brain-based learning.In E. Sorensen, \& D. O Murchu (Eds.),Enhancing learning through technology(pp. 292-322). Hershey, PA: Idea Group Inc.

- Connell, J. D. (2005). Brain-based strategies to reach every learner: Surveys, questionnaires, and checklists that help you identify student'sstrengths-plus brain-based lessons and activities for engaging every learner. New York: Scholastic. 
- Caine, R. N., Caine, G., McClintic, C., \&Klimek, K. (2005). 12 brain/mind learning principles in action: The fieldbook for making connections, teaching, and the human brain. Thousand Oaks, Calif: Corwin Press.

- Duman, B. (2006). The effect of brain-based instruction to improve on students' academic achievement in social studies instruction. Paper presented at $9^{\text {th }}$ International Conference on Engineering Education, Faculty of Education, Mugla University, 23-28 July.

- Duman, B. (2010). The effects of brain-based learning on the academic achievement of students with different learning styles. Educational Sciences: Theory and Practice, 10(4), 2077-2103.

- Heatherton, T. F., \&Wyland, C. L. (2003). Assessing self-esteem. In S. J. Lopez, \& C. R. Snyder (Eds.),Positive psychological assessment: A handbook of models and measures(pp. 219-233). Washington, DC, US: American Psychological Association.

- Jensen, E. (2005). Teaching with the brain in mind ( $\left.2^{\text {nd }} E d\right)$. Alexandria, Va: Association for Supervision and Curriculum Development (ASCD).

- Lawrence, D. (2006). Enhancing self- esteem in classroom ( $\left.3^{\text {rd }} \mathrm{Ed}\right)$. London: Paul Chapman Publishing.

- Miller, D., \& Moran, T. (2012). Self- esteem: A guide for teachers. London: SAGE Publications Ltd.

- Moreno, R. (2010). Educational psychology. New York: John Wiley \& Sons, Inc.

- Ozden, M., \& Gultekin, M. (2008). The effects of brain-based learning on academic achievement and retention of knowledge in science course. Electronic Journal of Science Education, 12(1), 4-19.

Retrieved from 
$$
\wedge r
$$

https://www.researchgate.net/publication/237595654_The_Effects_of_Brai n-

Based_Learning_on_Academic_Achievement_and_Retention_of_Knowled ge_in_Science_Course

- Schunk, D. H. (2012). Learning theories: An educational perspective $\left(6^{\text {th }}\right.$ Ed). Boston, MA: Pearson Education Inc.

- Sousa, D. A. (2017). How the brain learns ( $5^{\text {th }}$ Ed). Thousand Oaks, Calif.: Corwin Press.
\end{abstract}




$$
\text { 1. ملاحق الدراسة: }
$$

عزيزتي الطالبة،،،السلام عليكم ورحمة الله وبركاته،،،

نضع بين يديك مقياساً يسأل عن تقدير الذات. و المطلوب تعبئته، وأخذ الملاحظات

$$
\text { الآتية بعين الاعتبار: }
$$

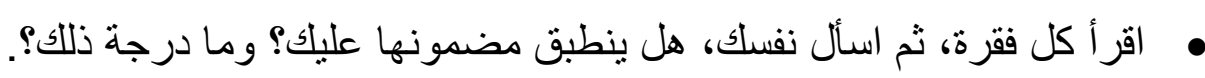

• أجب عن جميع الفقرات بوضع إنارة (x) تحت الإجابة التي تتطبق عليها

$$
\text { كل فقرة. }
$$

\begin{tabular}{|c|c|c|c|c|c|}
\hline \multicolumn{4}{|c|}{ التقلير } & \multirow[b]{2}{*}{ الفقرات } & \multirow{2}{*}{ رالفق } \\
\hline لا أو افق بشدة & لاأوافق & أوافق & أوافقد & & \\
\hline & & & & إنني راض عن نفسي، بشكل عام. & \\
\hline & & & & أعثقَّ أنني لست جيداً على الإطلاق. & \\
\hline & & & & أشثعر أن لآي عدد من الصفات الجيدة. & \\
\hline & & & & أنني قادر على القِّام بالأعمال كمظم الأشخاص الآخرين. & \\
\hline & & & & أشعر أنه ليس لدي الكثير لأفتخر به. & \\
\hline & & & & أشثعر أنه لا فائدة مني. & \\
\hline & & & & أشعر أنني شخص ذو قُيمةَ، على الأقلَ، بدرجة مساوية & \\
\hline & & & & أتمنى أن أحترم نفسي أكثر. & \\
\hline & & & & أشععر أنتي فاشل. & \\
\hline & & & & اتجاهي نحو نفّسي إيجابي. & \\
\hline
\end{tabular}

ماعلم أنه لا نوجد إجابة صحيحة وأخرى خاطئة.

سوف تعامل المعلومات بسرية ولغايات البحث العلمي فقط.

2. - 2 - مقياس الدافعية للإنجاز.

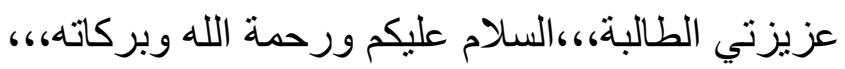


نضـع بـين بـديك مقياسـاً يسـأل عـن الدافعيـة للإنجـاز . و المطلـوب تعبئنـه، و أخــ

$$
\text { الملاحظات الآتية بعين الاعتبار : }
$$

• اقرأ كل فقرة، ثم اسأل نفسك، هل ينطبق مضمونها عليك؟ وما درجة ذلك؟. • أجب عن جميع الفقرات بوضع إثـارة (x) تحت الإجابة التي تتطبق عليها

كل فقرة.

• اعلم أنه لا توجد إجابة صحيحة و أخرى خاطئة.

• سوف تعامل المعلومات بسرية ولغايات البحث العلمي فقط. 


\begin{tabular}{|c|c|c|c|c|c|c|}
\hline \multicolumn{5}{|c|}{ التقدير } & \multirow[b]{2}{*}{ 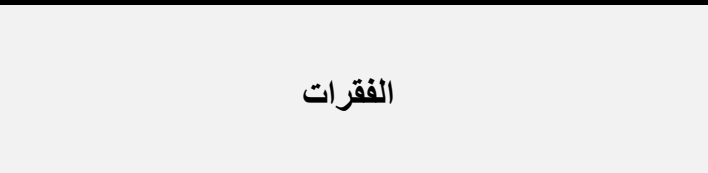 } & \multirow[b]{2}{*}{ 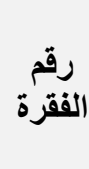 } \\
\hline بشديق & 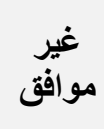 & 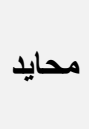 & 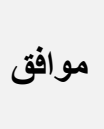 & 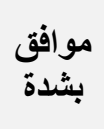 & & \\
\hline \multicolumn{7}{|c|}{ المثابرة } \\
\hline & & & & & لاي الرغبة في النجاح أكثر من زملائي الآخرين. & \\
\hline & & & & & أكرر المحاولة حتى أتقن الموضوع الذي أدرسه. & \\
\hline & & & & & أتعلم المواد التي تثكل تحدياً لي؛ لأنها تكسبني معلومات & \\
\hline & & & & & أسعى نحو النجاح لأنه يحقق الاحتر ام. & \\
\hline & & & & & أؤدي أعمالي وواجباتي بنفس اللحظة. & \\
\hline & & & & & أستمتع بالقيام بالأعمال الصعبة التي تثكل تحدياً لقدراتي. & \\
\hline & & & & & أنصرف إلى ممارسة بعض في الهواياتة في حال واجهتني & \\
\hline & & & & & لدي التصميم والإصرار على إتمام أي عمل صعب. & \\
\hline & & & & & يشجني النجاح في عمل ما علي محاولة القيام بعمل أكثر & \\
\hline & & & & & أبذل قصارى جهاي لرفع مستواي العلمي. & \\
\hline \multicolumn{7}{|c|}{ الثقة بالنفس } \\
\hline & & & & & عندما يكلفني المدرس بعرض موضو ألقيه بكلة أمام الطلبة فإنني & \\
\hline & & & & & أثق بقدرتي على اتخاذ القرارات. & \\
\hline & & & & & أعتمد على نفسي في دراستي. & \\
\hline & & & & & أستطيع تجاوز المصاعب التي أتعرض لها. & \\
\hline & & & & & أثثى في قدرتي على إقتاع الآخرين. & \\
\hline & & & & & أستطيع أن أتعامل مع أي موقف أكون فيه. & \\
\hline & & & & & أتحمل المشكلات والأعباء التي أواجهها. & \\
\hline & & & & & إذا انتقدني زملائي في موضاء المحاضرة؛ فِانني أتقبل ذلك & \\
\hline & & & & & أريد النجاح لإظهار براعتي أمام الآخرين. & \\
\hline & & & & & أضع لنفسي أثناء الدراسة معايير عالية. & \\
\hline \multicolumn{7}{|c|}{ أهمية الوقت } \\
\hline & & & & & أنا في سباق مع الزمن من أجل النجاح. & \\
\hline & & & & & أشعر بأهمية الوقت. & \\
\hline & & & & & أفكر بأهدافي المستقبلية، وليس بإنجازاتي الماضية. & \\
\hline & & & & & أفضل قراعة الكتب العلمية في أوقات فراغي. & \\
\hline & & & & & لا أعتقد أن التخطيط للمستقبل هو مضيعة للوقت. & \\
\hline & & & & & أفضل قضاء الوقت في تعلم ما ينمي قدراتي ومهاراتي. & \\
\hline
\end{tabular}




\begin{tabular}{|c|c|c|c|c|c|c|}
\hline \multicolumn{5}{|c|}{ التقدير } & \multirow[b]{2}{*}{ 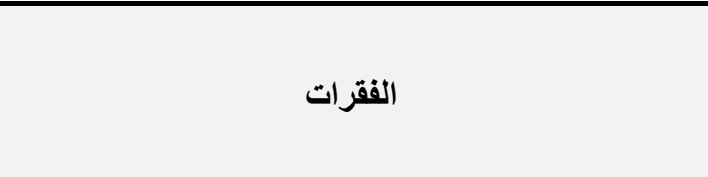 } & \multirow[b]{2}{*}{ الفقرة } \\
\hline بشئ بوافق & 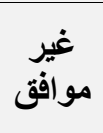 & محايد & 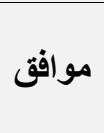 & 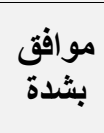 & & \\
\hline & & & & & أستفيد من وقت الفراغ المتاح في الدراسة. & \\
\hline & & & & & أتمنى أن يتم استثمار وقت المحاضرة. & \\
\hline & & & & & أستخل الوقت لكي أنجز الأعمال التي تطلب مني. & \\
\hline & & & & & أخطط لاستثمار الوقت. & \\
\hline \multicolumn{7}{|c|}{ 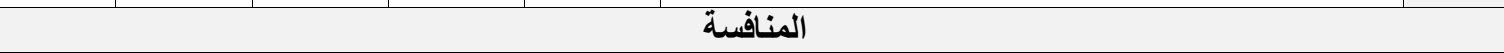 } \\
\hline & & & & & ي يهمني أن أتفوق على الآخرين. & \\
\hline & & & & & أسعى إلى تحدي الآخرين عند أداء مهمة ما. & \\
\hline & & & & & أتابع ما يبذله زملائي من جهد لكي أتفوق عليهم. & \\
\hline & & & & & أجيب على الأسئلة التي يطرحها المدرس قبل زملائي. & \\
\hline & & & & & أستمتع بمنافسة طلبة آخرين ممن هم في مستوى قدراتي. & \\
\hline & & & & & الأداء الجيد في الجامعة هو الأهم عندي. & \\
\hline & & & & & أقوم بأداء الواجبات على نحو أسرع من زملائي. & \\
\hline & & & & & أعجب بالأثخاص الذين يحققون مركزاً مرموقاً في الحياة. & \\
\hline & & & & & أملك العزم والتصميم على الفوز في أية منافسة. & \\
\hline & & & & & أساعد زملائي الذين يعانون من صعويات دراسية. & \\
\hline \multicolumn{7}{|c|}{ الرغبة في اتقان العمل والاستمتاع فيه } \\
\hline & & & & & يهمني إنجاز عملي على أكمل وجه. & \\
\hline & & & & & أستمتع بتعلم المواد المثيرة للاهتمام. & \\
\hline & & & & & أطمح إلى التمكن التام من المادة الاراسية. & \\
\hline & & & & & أريد تعلم أكبر قدر ممكن من المادة الاراسية. & \\
\hline & & & & & أستمتع بلراسة المواد التي لا تدخل في حساب معدلي & \\
\hline & & & & & آمل أن أحتفظ بمعرفة عميقة بالمَادة التعليمية بعد الاتتهاء & \\
\hline & & & & & أطرح الأسئلة في القاعة الصفية لأني أريد تعلم أثشياء & \\
\hline & & & & & أشعر بالرضا والسرور عندما أطور معلوماتي ومهاراتي & \\
\hline & & & & & أنجز الأعمال الموكلة إلي بشكل صحيح. & \\
\hline & & & & & أهتم بدراستي وأفضلها على أي عمل آخر. & \\
\hline
\end{tabular}

